UNITED STATES DEPARTMENT OF THE INTERIOR

J. A. Krug, Secretary

GEOLOGICAL SURVEY

W. E. Wrather, Director

Professional Paper 205-D

\title{
LATE MESOZOIC AND EARLY CENOZOIC HISTORY OF CENTRAL UTAH
}

\author{
BY \\ EDMUND M. SPIEKER
}

Shorter contributions to general geology, 1943-45

(Pages 117-161)

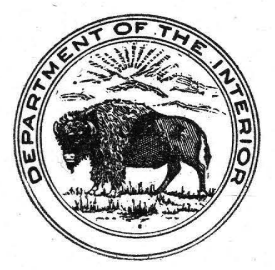

UNITED STATES

GOVERNMENT PRINTING OFFICE

WASHINGTON : 1946

For sale by the Superintendent of Documents, U. S. Government Printing Office, Washington 25, D. C.

Price 15 cents 
Note.-This repoit was finished by the author in 1940, and it takes no account of other reports published since that time. The stress of current conditions does not permit the additions and revision necessary to bring it up to date. Rather than delay the publication of the available material indefinitely, the paper is offered as it is. 


\section{CONTENTS}

Abstract

Introduction -1.

Background of present revision . . . . . . . . . . . . . . General setting.

Outline of investigation and summary of conclusion.

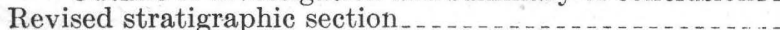
General features . . . . . . . . . . . . . . . . . Jurassic system Regional nomenclature ......................

Arapien shale _..._.

Definition, distribution, and general stratigraphic relations

Lithologic character, subdivision, and thickness

Age and correlation

Morrison (?) formation

Cretaceous system ...

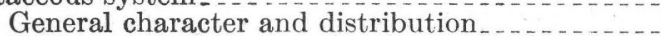

Indianola group

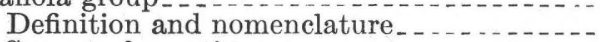

Sanpete formation

Allen Valley shale.....................

Funk Valley formation

Sixmile Canyon formation

Indianola group (undifferentiated)

Rocks of early and middle Montana age......

Price River formation

Definition and lithologic character

Distribution and stratigraphic relations...

Regional relations and correlation west-

wepresentative sections

Fossils

Cretaceous and Tertiary systems

North Horn formation Definition and lithologic character...... Regional characteristics _................... Relation to adjacent formations . . . . .....

Age and correlation
Use of term Paleocene
Revised stratigraphic section-Continued

Tertiary system _...... 135

Flagstaff limestone

Definition, lithologic character, and extent_- $\quad 135$

Regional relations..................... 136

Age and correlation................... 136

Pre-Flagstaff unconformity

Wasatch problem

Colton formation 139

Definition, general character, and relationships

Distribution

Age and correlation

Green River formation...................

Reconnaissance east of Wasatch Plateau _......... 140

West Tavaputs Plateau...................... 140

Green River Canyon

Cretaceous-Tertiary boundary problem ............. 142

General considerations _

Question of basis for time division

The orogenic record

The epeirogenic record

The paleontologic record. 146

Nature and extent of orogenic movements $\ldots \ldots$

Nomenclature.... 149

Scope of discussion 149

Mid-Cretaceous orogeny ...................... 150

Early Laramide orogeny ...

Pre-Flagstaff movement_.......... 155

Paleogeography and geologic history _................. 156

Diagrammatic reconstructions

Upper Jurassic and Lower Cretaceous _........... 156

Early Upper Cretaceous (Colorado) ............ 158

The geosyncline $\ldots \ldots \ldots$.

Early to Middle Montana _..................... 159

Late Montana and Lance

Paleocene (Fort Union) _........................ 160

Eocene (Wasatch and Green River)

Index $\ldots \ldots 161$

\section{ILLUSTRATIONS}

Plate 18. Arapien shale: $A$, At the type locality in Arapien Valley; $B$, In the Salina district.

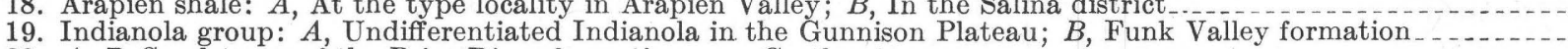

20. $A, B$, Sandstones of the Price River formation near Castlegate.

21. Conglomerates of the Price River formation, western facies: $A$, Conglomerate in Red Narrows, east of Thistle; $B$, Price River and Indianola strata on Hjork Creek

22. $A$, Flagstaff limestone on crest of Wasatch Plateau; $B$, North Horn formation at type locality

23. A, Colton and North Horn formations in Green River Canyon; B, Green River strata on Minnie Maud Creek.-

24. Unconformities beneath Price River and North Horn formations: $A$, North Horn formation in east front of Wasatch Mountains at Thistle; $B$, Price River-Indianola contact near Wales.

25. Unconformity beneath Flagstaff limestone: $A$, Flagstaff-North Horn unconformity in Sixmile district; $B$, Angular unconformity between Flagstaff limestone and Indianola group in Salina Canyon

FIGURE 14. Index map of part of Utah showing the localities discussed in this report

15. Relationships of stratigraphic units across the Wasatch Plateau, showing equivalence with units described in Cross sections showing relations of Arapien, Indianola, and Price River strata in northern Wasatch Plateau and central-eastern Gunnison Plateau.

17. Cross section of rocks exposed in Sixmile Canyon near Manti.

18. Stratigraphic diagram, northern Wasatch Plateau to Green River

19. Age determinations of Laramide orogeny in Europe

20. Map of western part of United States showing probable eastern margin of mid-Cretaceous folding

21. Block diagrams showing Utah north of latitude $39^{\circ} 30^{\prime}$ at four stages in late Cretaceous time 



\title{
LATE MESOZOIC AND EARLY GENOZOIC HISTORY OF GENTRAL UTAH
}

\author{
By Edmund M. Spieker
}

\section{ABSTRACT}

The discovery of dinosaur bones in strata of central Utah formerly assigned to the Wasatch formation, together with other findings, notably the recognition of a very thick section of conglomerates as Colorado in age, has made possible an outline of late Mesozoic and early Cenozoic history considerably different from the scheme hitherto conceived. Important changes are the recognition of an orogenic epoch in the eastern part of the Great Basin early in Upper Cretaceous time and the placing of the main Laramide folding of central Utah between middle and late Montana time instead of at the end of the Cretaceous, as heretofore thought. This paper presents the data bearing on these conclusions, together with many other stratigraphic and structural determinations that bear on the history and paleogeography of the region, and offers discussion of certain problems that are involved.

The stratigraphic section considered in this report begins with the Arapien shale, Upper Jurassic in age, a unit perhaps 10,000 feet thick of marine shale with beds of fine-grained sandstone, salt, and gypsum. Strata that possibly belong to the Morrison formation come next, and above them is a group of clastic rocks, ranging from boulder fan conglomerate to marine shale and including a wide variety of sedimentary types, 8,000 to 15,000 feet thick, named the Indianola group and subdivided where possible into four formations, as follows: The Sanpete at the base, sandstone and conglomerate, is of early Colorado age; the Allen Valley, marine shale, middle Colorado; the Funk Valley formation, sandstone and marine shale, late Colorado; and the Sixmile Canyon formation, conglomerate and sandstone with a finer-textured coal-bearing member, late Colorado. These strata grade eastward to the marine Mancos shale of Castle Valley and the Book Cliffs; westward they change rapidly to coarse conglomerates, red beds, and fresh-water limestones, with local marine beds, which accumulated in a rapidly subsiding piedmont belt. Strata of early and middle Montana age are similar to those of the eastern Wasatch Plateau and are not described.

The Indianola and older rocks are truncated by an angular unconformity, which was developed after the main Laramide folding. Above this unconformity is a conglomerate of late Montana age formerly classified as the basal Wasatch conglomerate but now correlated with the Price River formation of central and eastern Utah. Next above are the variegated mudstones and sandstones with local fresh-water limestone formerly included in the lower member of the Wasatch formation, now set apart as the North Horn formation. The lower part of this formation contains a dinosaurian fauna of probable Lance age, and the upper part contains mammalian faunas of Paleocene age; the Cretaceous-Tertiary boundary lies within the formation, unrecognizable by known physical criteria. Above the North Horn is the Flagstaff limestone, lacustrine in origin, formerly classified as the middle member of the Wasatch formation, possibly Fort Union (Paleocene) in age. On the west flank of the Wasatch Plateau the Flagstaff overlies all older beds in angular unconformity developed on a local fold. Elsewhere the basal Flagstaff is transitional with the North Horn.

Above the Flagstaff is a unit of red beds and gray sandstone, formerly considered to be the upper member of the Wasatch formation, now classified as the Colton formation, in the absence of definite evidence respecting its age. These beds are overlain by the Green River formation, with which they intertongue, disappearing westward so that in the northwestern part of the Wasatch Plateau there are no beds of Wasatch type; but the Flagstaff passes upward into the Green River formation with only slight change. East of the Wasatch Plateau the basal Green River and Colton intertongue further, and the Flagstaff thins to insignificance; on Green River at the mouth of Desolation Canyon the Flagstaff is doubtfully recognizable, and the upper
1,000 feet, approximately, of Colton strata is equivalent to basal Green River of the northeastern part of the Wasatch Plateau.

The Cretaceous-Tertiary boundary problem is affected by the new findings to the extent that the evidence of strong orogenic movement in the central Utah districts of the Cordillera is now found to be so far below the upper limits of characteristic Cretaceous strata that it can hardly be a factor in determining the boundary. Various possible criteria for the subdivision are discussed; orogenic movements are examined to determine possible values in correlation as prerequisite to consideration for subdivision, and it is concluded that the postulate of world-wide simultaneity is not demonstrated for the known late Mesozoic and early Cenozoic orogenic episodes. Clear differentiation between Cretaceous and Tertiary in most of the world is due to extensive epeirogenic movement and widespread withdrawal of the sea, the culmination of which might seem possible as a criterion, but the determination of an exact maximum is too difficult. The record of fossils, despite the fact that fossils are not necessarily precise indicators of contemporaneity, still affords the best available means of correlation, and a subdivision based solely on diagnostic fossils seems best. Question arises as to how the fossil evidence should be used. In the present problem it is logical to put the boundary at the horizon at which the greatest change takes place in total faunas from characteristic Cretaceous to characteristic Tertiary. In applying this criterion, the paleontologic opinion seems to favor for the interior of North America the boundary between the Lance and the Fort Union.

Three orogenic movements are recognized in the time span covered by this report, one at some time between the Upper Jurassic and the Upper. Cretaceous, probably early Colorado, here called the mid-Cretaceous movement; one between middle and late Montana times, called the early Laramide movement; the third probably in Paleocene time, not certainly dated and referred to the local stratigraphic section as the pre-Flagstaff movement. The mid-Cretaceous movement is not definitely proved by angular unconformity, but is virtually demonstrated by the nature of the conglomerates in the Indianola group and is thought to have affected a belt not far west of the southern Wasatch Mountains. Evidence in southern Idaho, the central Wasatch Mountains, and southern Nevada suggests that this movement may have been widespread. Uncertainty regarding the age of the basal conglomerates of the Indianola group prevents accurate estimate of date, but available evidence suggests early Upper Cretaceous or late Lower Cretaceous age. The second movement, the early Laramide, is accurately placed between the Blackhawk and Price River formations. Evidence of Laramide movement so early is generally lacking in the Cordilleran region, but nothing is known to controvert it, and in southwestern Montana there is suggestive evidence that the Laramide orogeny began at the time the Judith River formation was deposited. Districts east of the northern Rocky Mountain-Wasatch Mountain lineament, such as the Uinta Mountains and the Colorado Rockies, were probably folded later. The third movement, the pre-Flagstaff, was localized in central Utah in the SanpeteSevier Valley belt. Data on the age of the upper parts of the North Horn and Flagstaff formations suggest Fort Union age. Correlation with other regions is uncertain, but the character of the central Utah structure and the regional stratigraphy suggest that the movement was contemporaneous with the formation of the monoclines in the Colorado Plateau province, interpreted as the result of deep-seated thrusting.

The facts now available permit paleogeographic reconstruction of central and eastern Utah between the beginning of the Upper Cretaceous and the end of the Cretaceous. Four block diagrams show successive stages in the development of the predecessors of the Wasatch Mountains from late Mesozoic geosyncline. They also show areas toward the east in which the 
sediments of the existing rock section were deposited. In early Upper Cretaceous time the mountain belt was west of the present southern Wasatch Mountains and extended slightly east of north toward southeastern Idaho. The piedmont area was a rapidly subsiding trough in which coarse boulder and gravel fans spread out, and into which the sea spread at times; to the east lay locally swampy, sandy coastal plains and the open sea. Through Colorado time sedimentation was very active in the piedmont belt, 10,000 to 15,000 feet of strata, dominantly coarse, accumulating in the already pronounced geosyncline and bringing the total known thickness of pre-Montana rocks to more than 40,000 feet. This stage of the geosynclinal development is seen to be part of a series, beginning with the Cambrian, of epochs of profound subsidence, which shifted eastward and followed one another at progressively shorter intervals. In early and middle Montana time finer sediments were deposited, and the extensive coal beds of the Wasatch Plateau were formed; the sea retreated eastward as sediments were spread out into the marine basin, and epochs of accelerated subsidence caused successive reinvasions and intertonguing of the resulting sediments. Before late Montana time the early Laramide orogenic episode occurred, and the sediments of the geosyncline were folded as far east as the western border of the Wasatch Plateau. Debris from the mountains was spread widely eastward, part of it forming across eastern Utah an extensive sandstone tongue, the Castlegate member of the Price River formation. The sea reinvaded, burying these sands under muds, and then retreated as before, the shore zone reaching the eastern limits of Utah in late Montana time. In latest Cretaceous time flood plains and lakes overspread the region, and a variety of sediments accumulated; this sedimentation continued into Paleocene time without interruption or change. Probably in the middle Paleocene (Fort Union) another disturbance occurred, producing in the Sanpete Valley district a single fold, which was rapidly truncated and overlapped by the extensive Flagstaff Lake, in which limestone accumulated. Probably in Colton time floodplain sediments invaded from the east, and thereafter the lake spread eastward, depositing muds and calcareous deposits of the Green River formation over the whole of central and eastern Utah.

\section{INTRODUCTION}

In central Utah the late Mesozoic and early Cenozoic ages are recorded in a rock section of unusual interest. Until 1935 the region appeared to be entirely lacking in physical record of the time between the late Montana epoch of the Upper Cretaceous and the Wasatch epoch of the Eocene, but the discovery of dinosaurian remains in strata formerly classified as Wasatch has resulted in the abrupt shifting of a considerable section of rocks and a pronounced angular unconformity from a position in the stratigraphic column apparently well above the base of the Tertiary to one clearly within the limits of the Cretaceous. The closing stages of the Mesozoic are now seen to be well represented, instead of completely unrecorded. The main Laramide movement in this region is thus revealed to have taken place long before the end of the Cretaceous, instead of marking the end of the period as it has hitherto been thought to do. Further, the discovery of marine beds, Colorado in age, in another thick formation formerly classified as Tertiary has produced another major shift in stratigraphic alinement, which brings to light evidence of an orogeny older than the Laramide and also accentuates the magnitude of the Mesozoic geosyncline in the region. Finally, the determination that the youngest rocks exposed in the early Laramide folding of the area are of Colorado age, instead of Montana, as earlier thought, has led to other changes in correlation, which make possible a more precise dating of the main Laramide orogeny than was formerly thought feasible. In respect to certain elements of stratigraphic and orogenic succession, the record of physical events for the late Mesozoic is possibly more complete in central Utah than anywhere else in North America.
These discoveries require revision of the stratigraphic section, the paleogeography, and the general geologic history of the area. This report is intended to present the major facts and to discuss certain of the problems involved in the revision.

The data concerned have accumulated during the geologic mapping of the Wasatch Plateau and the reconnaissance examination of surrounding territory. In these tasks the writer has profited by advice and assistance from many more people than can expediently be mentioned here. Grateful acknowledgement must be made, however, to Hugh D. Miser for friendly support in the administration of the work and to John B. Reeside, Jr., for extensive consultation and collaboration in both field and office and for all identification of invertebrate fossils. The reptilian remains have been studied by C. W. Gilmore, of whose interest in the problem the writer is highly appreciative. Thanks are due also to G. G. Simpson and C. L. Gazin for opinions on mammalian remains, and to R. W. Brown for identification of fossil plants. Among associates in field parties of the Geological Survey, those who have contributed most toward the working out of the geology here described are M. P. Billings, A. W. Quinn, D. T. Griggs, and S. L. Schoff; it is a pleasure to acknowledge their important and whole-hearted cooperation. The writer is especially indebted to Mr. Schoff for permission to quote from his unpublished notes on the Cedar Hills. To other colleagues in the Survey, notably J. B. Reeside, Jr., Arthur A. Baker, J. D. Sears, W. W. Rubey, W. H. Bradley, and H. D. Miser, thanks are expressed for helpful criticism of this report in manuscript form.

\section{BACKGROUND OF PRESENT REVISION}

\section{GENERAL SETTING}

The Wasatch Plateau, the northernmost of the High Plateaus of Utah, is a high, deeply dissected tableland covering about 2,300 square miles in central Utah. (See fig. 14.) It forms part of the western highland rim of the drainage basin of the Colorado River, constituting not only the major divide between that basin and the interior drainage of the Great Basin to the west, but also the boundary between the rather distinct geologic provinces of those two regions. The eastern margin of the plateau is a sweeping stretch of barren sandstone cliffs, a southward continuation of the Book Cliffs, surmounted by higher tabular masses, in all of which the strata dip at low angles and are essentially parallel, in the general habit of the Colorado Plateaus. On the western margin the strata plunge toward Sanpete and Sevier Valleys in the great Wasatch monocline, at the base of which the structure is complex, and a variously deformed rock succession is broken by several angular unconformities; the geologic features here are typical of the Great Basin, and their eastern limit follows in a general way the western border of the plateau.

The rocks of the plateau have long been divided into two major groups: (1) a lower succession of sandstone and shale, buff to gray, prominent in the east front and in the Book Cliffs, marine in the lower part and continental in the upper, richly coal-bearing in part, of Cretaceous age; and (2) an overlying succession of notably different rocks in which varicolored sandstone and shale, conglomerate, and fresh-water limestone are prominent. In the past the beds of the upper group, which form most of the higher tabular masses in the 


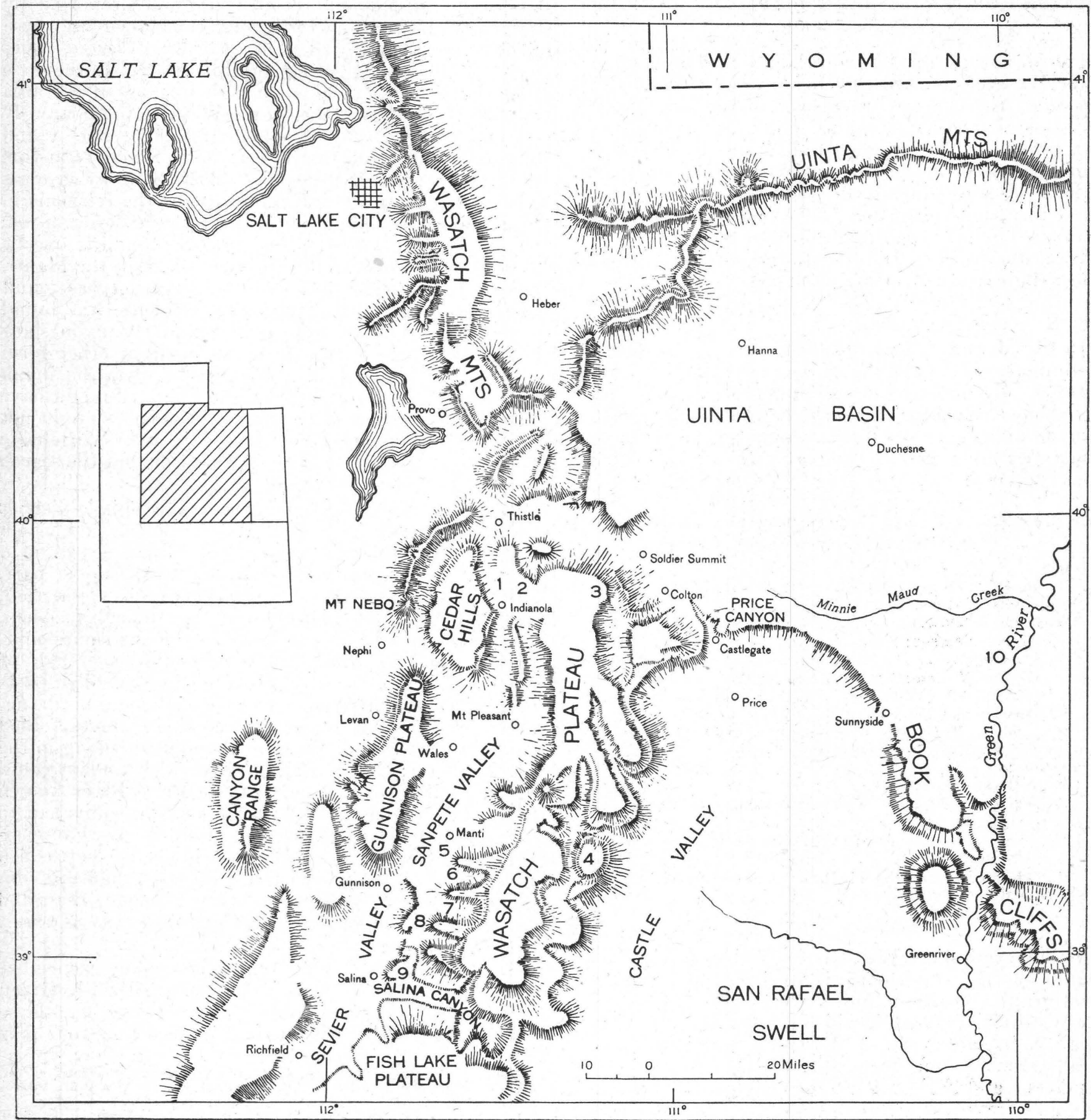

FIGURE 14.-Index map of part of Utah, showing the localities discussed in this report.

1. Dry Creek and Hjork Creek.

2. Little Clear Creek.

3. Bennion Creek.

4. North Horn Mountain
5. Allen Valley.

6. Sixmile Canyon.

7. Twelvemile Canyon.
9. Twist Gulch.

10. Mouth of Desolation Canyon on Green River. plateau, were believed to be Tertiary and were assigned to the Wasatch formation. On the western margin of the plateau and adjacent parts of Sevier and Sanpete Valleys, the complicated structure brings to exposure various rock units of both groups and also large areas of Jurassic shale; but highly varied rocks like those of the upper group predominate, and in many places their relations have been difficult to work out. In the western districts, in general, the younger upper strata were found to overlie the older in strong angular unconformity, whereas in the eastern districts the little-disturbed succession of strata seemed to show no evidence of corresponding break. The local Cretaceous-Tertiary boundary problem was thus complicated by the puzzling concealment in the eastern section of a disconformity that should, it seemed, represent not only the strong angular unconformity of the western section, but also the rather long interval between late Montana and early Eocene (Wasatch) times. These and other questions have been satisfactorily resolved by the recent work, as outlined in the following paragraphs. 


\section{OUTLINE OF INVESTIGATION AND SUMMMARY OF CONCLUSION}

The discovery of dinosaur bones in the supposed lower Wasatch marked the turning point from which proceeded the changes in concept of the stratigraphy and geologic history of central Utah mentioned above. This discovery was preceded and followed, however, by a number of other discoveries, hitherto unpublished, which were made during the writer's study and should be set forth in explanation of the revised stratigraphic section. The following paragraphs summarize the significant discoveries. In order to preserve unity in this chronologic account, stratigraphic names are given as used at the time the studies were made, whether or not they have since been changed.

In 1925 J. B. Reeside, Jr., and the writer published a preliminary account of the stratigraphy of the Wasatch Plateau, ${ }^{1}$ in which there was presented a type section of the late Cretaceous and early Tertiary beds for Price Canyon and vicinity. Further description of the section appeared in $1931 .^{2}$ The major units in this section are as follows:

Late Cretaceous and early Tertiary formations of the Wasatch Plateau (Price Canyon section)

Eocene:

Green River formation: Gray shale, sandstone, oil Feet shale, limestone.

wasatch formation:

Upper member: Sandstone, red shale; irregularly bedded 1,500

Flagstaff member: Limestone, shale, sandstone; regularly bedded

Lower member: Sandstone, gray to variegated shale, limestone, conglomerate, thin coal beds; irregularly to evenly bedded

Cretaceous :

\section{Price River formation:}

Upper member: Coarse gray sandstone, shale; irregularly bedded.

Castlegate member: Cliff-making gray sandstone

Blackhawk formation: Medium to fine-grained buff sandstone, shale, coal

Total (maximum)

In this section the Wasatch formation was identified almost entirely on the basis of lithologic character, stratigraphic position, and connection by tracing with the Wasatch strata as identified to the east. At the type locality, in southwestern Wyoming and northeastern Utah, the Wasatch formation consists of variegated sandstone and shale, with some conglomerate, volcanic ash, and fresh-water limestone. ${ }^{3}$ Strata of these wellknown lithologic types have been traced in a general way, locally in accurate detail, across southwestern $\mathrm{Wy}$ oming into northwestern Colorado and along the Book Cliffs into central Utah. ${ }^{4}$ Fossil evidence was meager, and the actual basis for assignment to the Wasatch was rather weak-in fact, as now reviewed, it consisted largely of tradition. Since the days of Powell and Dutton these strata had been identified as Tertiary, and in the absence of proof to the contrary the classification had been accepted and handed on. The fact that in the disturbed districts the strata are unconformable on the folds produced in the so-called Laramide revolution and conceived to mark the end of the Cretaceous appeared to support the determination of Tertiary age.

In 1926 the writer collected from the lower member of the Wasatch fresh-water mollusks that augmented collections already on record, ${ }^{5}$ and were reported by Reeside to include several species not known elsewhere in beds later than Fort Union. Certain of these species were found also in the Flagstaff limestone. In the same year the Flagstaff, which throughout most of the area overlies the lower member of the Wasatch in apparently transitional conformity, was found to overlie it and older rocks in angular unconformity in Sixmile Canyon, south of Manti. (See fig. 17.) At that time there was some doubt as to the interpretation of the relations in Sixmile Canyon because of locally severe deformation, but in 1929 and 1930 the Flagstaff was found to overlie in angular unconformity all older rocks in the MantiSalina district. In 1932 a similar situation was found farther north, and finally in 1934 evidence was found to prove that the exposures in Sixmile Canyon show angular unconformity and not shearing or other form of faulting. This evidence suggested that the break between the lower member and the Flagstaff might have time significance, and that the lower member might not be Wasatch, but rather Fort Union, in age. Vertebrate fossils were needed to settle the question, but the search for bones went unrewarded.

In 1931 it was discovered that in the Thistle district the basal conglomerate of the Wasatch formation, which there overlies folded Cretaceous and Jurassic strata in angular unconformity, is equivalent to the upper part at least, of the Price River formation of the type section. but correlation of the lower part was a difficult problem Brackish-water fossils not far above the Castlegate sandstone member ${ }^{6}$ showed that roughly the lower half of the formation, at least, is Montana in age. The postorogenic conglomerates and sandstones could not be accepted as Montana in age, because the youngest folded rocks in the western belt were thought to belong in the late Montana $;{ }^{7}$ but in Price Canyon no boundary could be found between the part of the Price River known to be of Montana age and the upper beds equivalent to the postorogenic conglomerate. This discovery intensified the difficulty of locating the break in the eastern section, but on the other hand it revealed the basal con glomerate of the Wasatch as more extensive than had earlier been thought and brought it into view as a unit of regional importance.

In the same year it was found that the upper member of the Wasatch formation intertongues with Green River strata between Soldier Summit and Thistle so that in the Thistle district the Flagstaff limestone may

${ }^{1}$ Spieker, E. M., and Reeside, J. B., Jr., Cretaceous and Tertiary for mations of the Wasatch Plateau, Utah. Geol. Soc America Bull, vol. 3 pp. $435-454,1925$.

${ }^{2}$ Spieker, E. M., The Wasatch Plateau coal field, Utah: U. S. Geol Survey Bull. 819, pp. 39-47, 1931.

${ }^{3}$ Hayden, F. V., U. S. Geol. Survey Terr., 3d Ann. Rept., p. 90, 1869 idem, 2d ed., p. 191, 1873. Veatch, A. C., Geography and geology of portion of southwestern Wyoming: U. S. Geol. Survey Prof. Paper 56 pp. 88-96, 1907.

4 Wegemann, C. H.. The Coalville coal field, Utah : U. S. Geol. Surve Bull. 581, pp. $161-184,1915$. Schultz, A. R., The southern part of th Rock Springs coal field: U. S. Geol. Survey Bull. 381, pp. 214-281, 1910 Gale, H. S., Coal fields of northwestern Colorado and northeastern Utah U. S. Geol. Survey Bull. 415, 1910. Richardson, G. B., Reconnaissanc
of the Book Cliffs coal field: U. S. Geol. Survey Bull. 371, 1909. Clark of the Book Cliffs coal field: U. S. Geol. Survey Bull. 371, 1909. Clark F. R., Economic geology of the Castlegate, Wellington, and Sunnysia
quadrangles : U. S. Geol. Survey Bull. 793, 1928. Sears, J. D., Geolog? quadrangles : U. S. Geol. Survey Bull. 793, 1928. Sears, J. D., Geolog.
and oil and gas prospects of part of Moffatt County, Colo., and souther and oil and gas prospects of part of Moffatt County, Colo., and souther
Sweetwater County, Wyo.: U. S. Geol. Survey Bull. 751, pp. 269-319
1924. Sears, J. D., and Bradley, W. H., Relations of the Wasatch an 1924. Sears, J. D., and Bradley, W. H., Relations of the Wasatch an ming: U. S. Geol. Survey Prof. Paper 132, pp. 93-107, 1925. Fisher D. J., The Book Cliffs coal field in Emery and Grand Counties, Utah coal field in Garfield and Mesa Counties, Colo. : U. S. Geol. Survey Bull \$51, 1934.

${ }^{5}$ Spieker, E. M., and Reeside, J. B., Jr., op. cit., pp. 450-451.

- Spieker, E. M., and Reeside, J. B., Jr., op. cit., p. 446.

in Utah: Geol. Soc. America Bull., vol. 37, pp. 429-438, 1926. 
be regarded as basal Green River (see fig. 18); this raised the question whether the Flagstaff should be classified as a tongue of the Green River.

In 1932 a formation much like the Wasatch formation was discovered in the Indianola district, south of Thistle. It underlies the basal conglomerate of the Wasatch in angular unconformity and overlies the folded Jurassic of the area in a deformed contact suspected of being a lower angular unconformity. These relations suggested two stages of folding instead of the one earlier - pictured. Subsequent field work revealed a considerable extent of this new formation in the western border belt; it had earlier been regarded as Wasatch and had been the source of much difficulty in the Salina district because of its dissimilarity there to Wasatch strata nearby to the east, in structurally separated outcrops.

The need for definite paleontologic evidence on the age of the beds classified as Wasatch, and of the new formation as well, thus became increasingly important. In 1934 the writer examined the type Wasatch, did some regional tracing of the strata, and searched for further fossil evidence. One locality in the Wasatch Plateau, on North Horn Mountain (location 4 on fig. 14), yielded an assortment of bone scraps that were identified by C. W. Gilmore as mainly dinosaurian. This discoverly led to further collecting, and in $1935 \mathrm{~J}$. B. Reeside, Jr., joined the writer in a visit to the Wasatch Plateau that established the presence in the "lower Wasatch" of indigenous dinosaurian remains in considerable variety. Gilmore concluded on study of these fossils that they represent a late Cretaceous fauna, probably Lance in age. A short note announcing the discovery of the dinosaurian material was published. ${ }^{8}$

In this search the upper levels of the lower member of the "Wasatch" formation yielded no dinosaurs, but they did yield a mammalian fragment, estimated by G. G. Simpson and C. L. Gazin to be worthless for precise determination, but probably not Cretaceous in age. No physical basis for regional subdivision of the beds concerned was then recognized, nor has it yet been; the top of the Cretaceous, indistinguishable by other than faunal means, apparently lies in the middle or upper part of the beds formerly thought to constitute the lower member of the Wasatch.

In 1936 Schoff $^{9}$ discovered in the Cedar Hills (see fig. 14) a thick section of conglomerate, red beds, freshwater limestone, buff sandstone and gray shale, parts of which contain marine fossils of Colorado age. This section is equivalent to a succession of beds in the Gunnison Plateau that had earlier been determined by the writer to be the same as the unit under the basal conglomerate of the Wasatch in the Indianola district, observed in 1932. To check the unexpected regional correlation brought out by this development, Schoff and the writer examined several localities in the Gunnison Plateau, the Cedar Hills, and the Indianola district and verified the conclusion that the western succession of conglomerates, red beds, etc., is equivalent to the marine Colorado of the Wasatch Plateau. It was also found that these beds, to all appearance, are involved equally with the Jurassic in the folding of the Gunnison Plateau, and that the deformed contacts in the Wasatch Plateau do not demonstrate angular discordance; the earlier folding therefore probably did not penetrate the parts of central Utah here described, although the na- ture of the conglomerates proves disturbance not far to the west.

In 1935 Reeside and the writer had collected fossil plants in Sixmile Canyon, south of Manti (see fig. 14), from the youngest folded strata under the basal conglomerate of the Wasatch, earlier thought to be late Montana in age, as stated above. These fossils were assigned by R. W. Brown to the so-called Dakota flora. The plant-bearing strata had been determined to overlie sandstone and shale of proved Niobrara age, and to resolve the question thus raised the writer reexamined the structure in the Sixmile area, and collected more fossil plants and also mollusks. These fossils were reported by Brown and Reeside, respectively, to be Colorado in age. This removed the only evidence extant in favor of post-Montana age for the folding. A review of the relations in the northern part of the area showed that the "Wasatch" conglomerate is equivalent to the Price River formation; the break in the eastern section lies at the base of the Castlegate sandstone member, where Reeside and the writer had earlier postulated a hiatus. ${ }^{10}$

In 1937 C. W. Gilmore, G. W. Sternberg, and G. B. Pearce, of the Smithsonian Institution, spent about 5 weeks in the central part of the Wasatch Plateau, collecting vertebrate remains from the beds earlier examined by Reeside and the writer. During the first half of this work the writer joined the Smithsonian party. The material collected greatly augments the results of the earlier work, giving a much more definite picture of the dinosaurian fauna, and, most important, verifying the Paleocene ${ }^{11}$ age of the bone-bearing strata above the dinosaur zone. Studies of these fossils by Gilmore and Gazin confirm the conclusions as to age tentatively offered on the earlier, less distinctive collections.

The progressive alterations of the stratigraphic scheme arising out of these discoveries are now brought together in a revised section which seems to embody no major uncertainties. The main points of the revision may be concisely stated as follows: (1) Abandonment of the classification as Wasatch of the three units formerly designated as members of that formation; (2) recognition of the basal conglomerate of the former lower member of the Wasatch formation as equivalent to the original Price River formation, and distinction of the overlying part of the lower member as the North Horn formation; (3) establishment of the Flagstaff limestone as an independent formation; (4) adoption of the name Colton formation for the upper member of the Wasatch formation as originally classified; (5) naming the new unit beneath the Price River in the western districts the Indianola group, subdivided where feasible and undifferentiated where not; (6) assignment to the Cretaceous of all beds up to and including the highest dinosaur zone, and assignment to the Paleocene of the overlying part of the North Horn formation. For easy comparison with the previous scheme, the resulting new section is diagrammatically presented in figure 15 .

\footnotetext{
${ }^{8}$ Spieker, E. M., Orogenic history of central Utah: Science, vol. 83 pp. 62-63, 1936 . 9 Schoff, S. L., Geology of the Cedar Hills, Utah : Ohio State Univ. Abstracts of Doc. Dissert. 25, pp. 375-386, 1937.

10 Spieker, E. M., and Reeside, J. B., Jr., Cretaceous and Tertiary formations of the Wasateh Plateau, Utah. Geol. Soc. America Bull., vol. 36 , p. 447,1925 .

(the term Paleocene see p. 135 of this paper.
} 


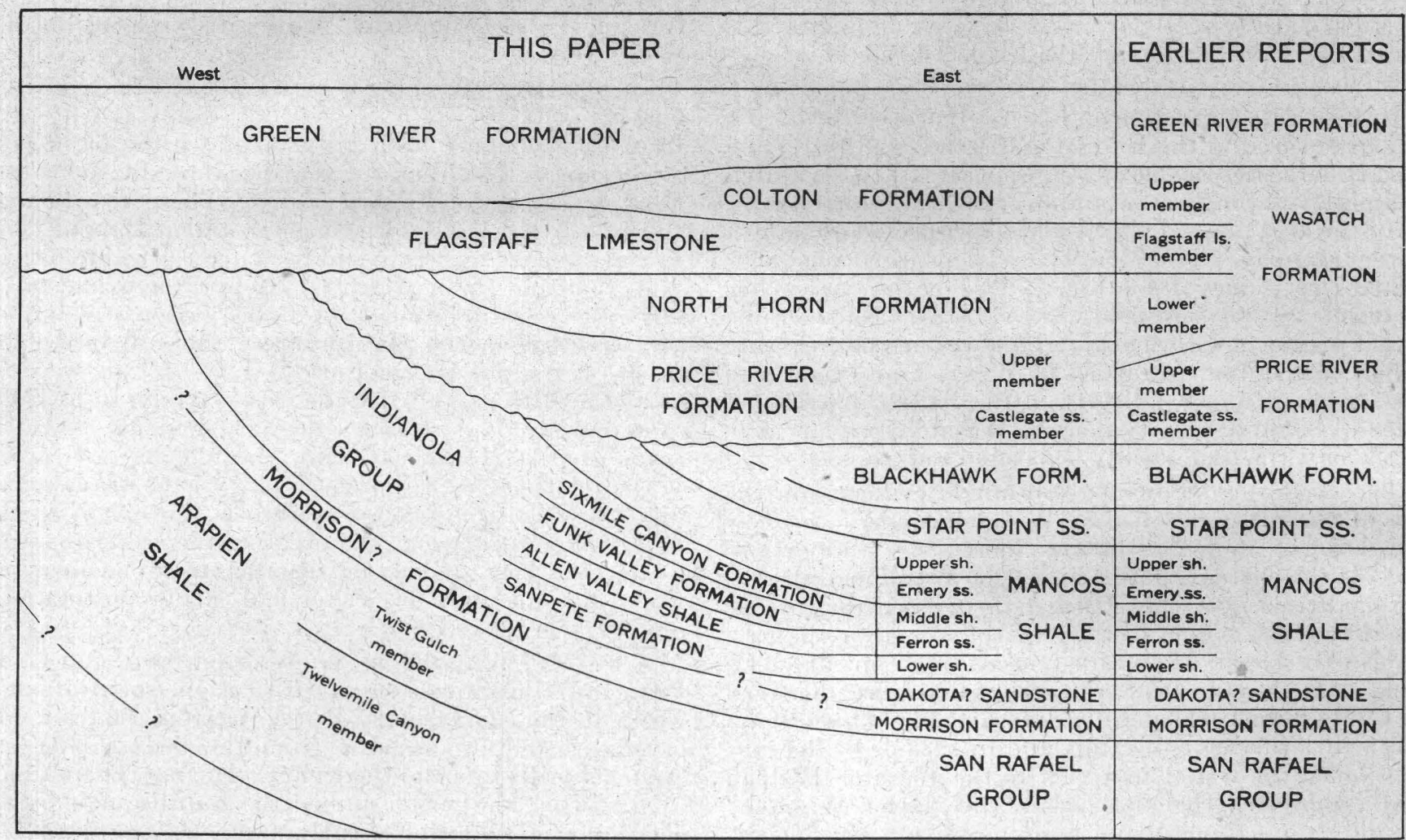

FIGURe 15.-Relationships of stratigraphic units across the Wasatch Plateau, showing equivalence with units described in earlier reports. Angular unconformities are shown by wavy lines.

\section{REVISED STRATIGRAPHIC SECTION}

\section{GENERAL FEATURES}

The rocks with which this paper is concerned range in age from Upper Jurassic to Eocene. The stratigraphic units now recognized in this section are tabulated below. Two equivalent but notably different sections are found in the region, one in the eastern part of the Wasatch Plateau and adjacent parts of Castle Valley and the San Rafael Swell, and the other in the western part of the Wasatch Plateau and adjacent parts of the Sanpete and Sevier Valleys. As to actual boundaries of units the eastern section now stands unchanged from the form earlier published, ${ }^{12}$ and it need

${ }_{12}$ Spieker, E. M., The Wasatch Plateau coal field, Utah : U. S. Geol. Survey Bull. 819, pp. 15-48, 1931 .

Table of formations, northern and western borders of Wasatch Plateau, Utah

\begin{tabular}{|c|c|c|c|c|c|}
\hline System & Series & & Group and formation & Character & $\begin{array}{l}\text { Thickness } \\
\text { (feet) }\end{array}$ \\
\hline \multirow{4}{*}{ Tertiary. } & \multirow{2}{*}{ Eocene. } & \multicolumn{2}{|c|}{ Green River formation. } & $\begin{array}{l}\text { Gray to green-gray shale, oil shale, gray to buff sandstone, fresh-water } \\
\text { limestone. }\end{array}$ & $5,000+$ \\
\hline & & \multicolumn{2}{|c|}{ Colton formation. } & $\begin{array}{l}\text { Red shale, gray sandstone, with some gray and yellow shale and brown, } \\
\text { green, and pink sandstone. }\end{array}$ & $0-1,500$ \\
\hline & Paleocene (?). & \multicolumn{2}{|c|}{$\begin{array}{l}\text { Flagstaff limestone. } \\
\text { Local uneonformity }\end{array}$} & Limestone, gray shale, gray sandstone, some oil shale. & $300-1,500$ \\
\hline & Paleocene. & \multicolumn{2}{|c|}{ North Horn formation. } & Variegated shale, buff to gray sandstone, conglomerate, some limestone. & $500-2,400$ \\
\hline \multirow{4}{*}{ s } & \multirow{7}{*}{ Upper Cretaceous. } & \multicolumn{2}{|c|}{ Price River formation. } & Gray sandśtone, grit, conglomerate, local gray shale. & $700-2,000$ \\
\hline & & \multirow{6}{*}{ 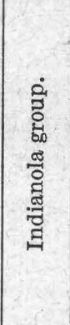 } & \multirow{3}{*}{ Sixmile Canyon formation. } & Coarse gray sandstone, conglomerate, boulder beds in upper part. & $400+$ \\
\hline & & & & Cream to buff sandstone, gray to black shale, coal; partly brackish water. & 300 \\
\hline & & & & Coarse gray sandstone and conglomerate. & 2,100 \\
\hline \multirow[t]{3}{*}{ Cretaceous. } & & & Funk Valley formation. & $\begin{array}{l}\text { Sandstone, cream, buff, brown, white, thin-bedded to massive, with in- } \\
\text { tercalated shale; unit of gray shale } 650 \text { feet thick near middle; marine, } \\
\text { Niobrara in age. }\end{array}$ & 2,250 \\
\hline & & & Allen Valley shale. & $\begin{array}{l}\text { Shale, gray, with thin layers of bentonite, gray limestone, and fine sand- } \\
\text { stone; marine, Carlile in age. }\end{array}$ & $600-800$ \\
\hline & & & Sanpete formation. & $\begin{array}{l}\text { Sandstone, brown, buff, gray, fine to coarse; shale in thin beds; conglom- } \\
\text { erate in upper and lower parts; largely marine. }\end{array}$ & 1,350 \\
\hline \multirow{3}{*}{ Jurassic. } & \multirow{3}{*}{ Upper Jurassic. } & \multicolumn{2}{|c|}{ Morrison (?) formation. } & Gray sandstone, conglomerate, variegated shale. & 1,050 \\
\hline & & \multirow{2}{*}{ 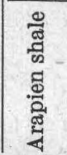 } & Twist Gulch member. & $\begin{array}{l}\text { Siltstone and shale, red, in thin-bedded succession, with many thin beds } \\
\text { of green-gray to white siltstone. }\end{array}$ & 3,000 \\
\hline & & & Twelvemile Canyon member. & $\begin{array}{l}\text { Shale, gray in lower part, with prominent red blotches in main part, deep } \\
\text { red and salt-bearing in upper } 500 \text { feet: beds of sandstone and gypsum in } \\
\text { middle. }\end{array}$ & $7,000+$ \\
\hline
\end{tabular}


not be repeated here; changes of nomenclature and age assignment in the Wasatch and Price River formations, as well as mutual equivalencies between the eastern and western sections, are shown in figure 15.

In general the formations of the western section differ from those of the eastern section in characteristics that reflect greater proximity to mountains and the scene of mountain building. The Jurassic rocks are enormously thicker there than to the east, owing to their accumulation in a strongly downwarping part of the Wasatch geosyncline. The rocks of Colorado age are not only thicker, but also coarser, and they bear witness to orogenic disturbance nearby to the west, showing rapid lateral change eastward from piedmont and other continental conditions to littoral and offshore marine conditions. Early and middle Montana time are not represented in the area affected by Laramide folding, because of removal by postorogenic erosion of uplifted sediments equivalent to the upper part of the Mancos, Star Point, and Blackhawk formations, but in the central part of the western belt the Blackhawk formation is present and is similar lithologically to the eastern Blackhawk but thicker. As to the late Montana rocks, the Price River formation is generally thicker and coarser, culminating in these respects in the district south of Thistle, where it is a very thick and prominent conglomerate. Above the upper Montana the formations of the western belt begin to resemble those of the east more closely, and the North Horn strata differ from their equivalents on the east front of the plateau chiefly in a general though not complete absence of fresh-water limestone, and consequently in a dominance of clastic sediments. In the parts of the belt closest to the source area the North Horn formation is more brightly colored than to the east. The Flagstaff limestone of the western area differs largely in greater thickness, the Colton formation differs hardly at all, and except for the results of extensive intertonguing between these two formations they are fairly uniform across central Utah. The Green River formation of the west shows local differences, having a greater content of limestone in some places and of coarse sandstones in other places, but on the whole it, too, is regionally much the same.

\section{JURASSIC SYSTEM}

\section{REGIONAL NOMENCLATURE}

Jurassic rocks are exposed in the southwestern and northwestern border districts of the Wasatch Plateau, one area lying between Salina and the southern end of the Gunnison Plateau and the other between Indianola and Thistle. The dominant unit in both areas is a thick mass of marine shale, with some fine-grained sandstone, salt, and gypsum, described below as the Arapien shale. Above the Arapien are variegated beds, sandstones and conglomerates, provisionally assigned to the Morrison formation, as shown in the general stratigraphic table.

The nomenclature of these rocks, and especially those here referred to the Arapien shale, presents a problem in that the area lies between two regions in which Jurassic strata probably equivalent in large part to the central Utah beds have been classified in two different schemes, both of which have been widely used. Instead of being clearly correlatable with either of these two sections, the strata of central Utah are in important respects different from both. To the north, in the Wasatch and Uinta Mountains and adjacent country in northeastern Utah and southwestern Wyoming, Jurassic nomenclature has been largely derived from the section established by Veatch ${ }^{13}$ for squthwestern Wyoming, whereas to the east and south, in the Colorado Plateaus, the section of the San Rafael Swell has largely served as standard, and the stratigraphy has been worked out over a large area to a degree of accuracy rarely possible in geologic work. ${ }^{14}$ Although very complex in details of internal stratigraphy, the Jurassic section in its broad outlines is much the same over the entire region, consisting of a basal unit of cross-bedded sandstone, probably continental in origin, a middle unit of shale, sandstone, limestone and gypsum, largely marine, and an upper unit of variegated beds, sandstones and conglomerates, continental in origin. Wherever recognized the upper unit has been identified as the Morrison formation. In the Colorado Plateau the middle unit is the San Rafael group, and it is roughly equivalent to the Twin Creek limestone as identified in the Wasatch Mountains, although this Twin Creek includes, in addition to the type Twin Creek, at least some of the Beckwith formation of Veatch's original section for southwestern Wyoming. ${ }^{15}$ The Nugget sandstone is probably equivalent to the Navajo of the southern section.

The Arapien shale of central Utah appears to correspond roughly with the San Rafael group but is much thicker and cannot be subdivided into units definitely correlatable with the formations of the San Rafael Swell. In view of the striking lateral changes brought out by Baker, Dane, and Reeside for the large area to the east and south, it is not safe, with data now available, to bridge the gap of about 40 miles between Salina Canyon and the San Rafael Swell with anything more than a generalized correlation. To the north correlation is likewise uncertain, although it is likely that the Arapien of the northwestern part of the Wasatch Plateau is equivalent in large part to the so-called Twin Creek of the central Wasatch Mountains. Extension of the name Twin Creek, considering the departure from the typical sense already evident in the Wasatch Mountains, is undesirable. Another element of uncertainty is introduced by the absence, in extensive and highly deformed exposures of Jurassic rocks in central Utah, of the basal sandstone unit that is uniformly present elsewhere, although this phenomenon may be explained on structural grounds. In southern and southwestern Utah, on the other hand, there is probably a considerable area in which the Arapien shale may be recognized. For these reasons the section as here described is not designated by any of the preexisting terms available.

\section{ARAPIEN SHALE}

\section{DEFINITION, DISTRIBUTION, AND GENERAL STRATIGRAPHIC RELATIONS}

The name Arapien shale is here given to the body of red to gray shale and fine-grained sandstone, salt- and gypsum-bearing in part, referred to in existing publications ${ }^{16}$ simply as Jurassic shale, which crops out prom-

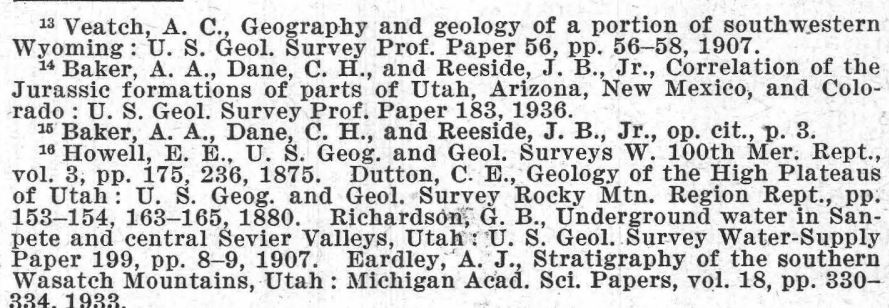
13 Veatch, A. C., Geography and geology of a portion of southwestern
Wyoming: U. S. Geol. Survey Prof. Paper 56, pp. 56-58, 1907.
14 Baker, A. A., Dane, C. H., and Reeside, J. B., Jr., Correlation of the
Jurassic formations of parts of Utah, Arizona, New Mexico, and Colo-
rado : U. S. Geol. Survey Prof. Paper 183,1936 .
15 Baker, A. A., Dane, C. H., and Reeside, J. B., Jr., op. cit., p. 3.
16 Howell, E. E., U. S. Geog. and Geol. Surveys W. 100th Mer. Rept.,
vol. 3, pp. 175, 236, 1875. Dutton, C. E., Geology of the High Plateaus
of Utah : U. S. Geog. and Geol. Survey Rocky Mtn. Region Rept., pp.
$153-154,163-165,1880$. Richardson, G. B., Underground water in San-
pete and central Sevier Valleys, Utah: U. S. Geol. Survey Water-Supply
Paper 199, pp. 8-9, 1907 . Eardley, A. J., Stratigraphy of the southern
Wasatch Mountains, Utah : Michigan Acad. Sci. Papers, vol. 18, pp. 330$334,1933$. 
inently in a belt 2 to 3 miles wide on the east side of Sevier Valley along the margin of the Wasatch Plateau. It begins at the southern end of Sanpete Valley, near the main highway about 5 miles east of Gunnison, and extends southward past Salina to a point about 6 miles southeast of Richfield. The name is taken from Arapien Valley, which lies parallel to the base of the Wasatch Plateau about 6 miles southeast of Gunnison, and on the west side of which the formation is typically if not completely exposed. In all this area the upper limit of the formation has been found clearly exposed at only one place-in Salina Canyon, where the overlying beds are the sandstone, conglomerate, and variegated shale of the Morrison (?) formation. The base of the Arapien has not been found in the entire region south of the Wasatch Mountains. In the Wasatch Mountains near Thistle the limestone and shale that are probably correlative with the Twin Creek limestone of the central Wasatch overlie cross-bedded sandstone, the Nugget, but correlation of these beds with the Arapien is not precise enough to allow a conclusion respecting the probable basal relations in the districts farther south.

In addition to the belt along the margin of the Wasatch Plateau, the Arapien shale occurs in scattered outcrops through Sevier Valley and in a continuous belt that extends along the western base of the Gunnison Plateau to the southern end of the Wasatch Mountains, where the exposures at the foot of Mount Nebo have been described by Eardley. ${ }^{17}$ There are also a few disconnected outcrops in the district north of Indianola. On the west side of the Gunnison Plateau the upper contact is exposed. There the overlying strata are conglomerates and sandstones with some freshwater limestone, which, as seen in reconnaissance, afford no evidence favoring identification as Morrison, and which are tentatively regarded as belonging with the Indianola group (undifferentiated). On the east side of the Gunnison Plateau, due west of Wales, the uppermost Arapien also is present, overlain by sandstones and conglomerates of the Indianola group, which are totally unlike the Morrison formation but clearly resemble the continental beds common in the Upper Cretaceous of the region. The uppermost Arapien is present also in the district north of Indianola, but it is poorly exposed and has been deformed to an extent that makes the determination of stratigraphic relations uncertain. Near Thistle the formation is overlain by strata like those in Salina Canyon, which may belong to the Morrison formation.

\section{IITHOLOGIC CHARACTER, SUBDIVISION, AND THICKNESS}

The Arapien shale may be roughly divided into two parts, the lower of which is dominantly gray, the upper dominantly red. This color distribution is, in fact, characteristic of the Jurassic rocks of similar age throughout Utah. In the area covered by this paper there are five different types of lithologic assemblage, in which the order of succession, beginning with the lowermost, is commonly but by no means regularly as follows: (1) Gray limestone, generally thin-bedded; (2) light-gray siltstone and shale, very thin-bedded, with occasional thin beds of finely rippled sandstone; (3) gray shale, argillaceous and gypsiferous, with irregular red blotches, which locally become dominant; (4) compact red salt-bearing shale; (5) thin-bedded red siltstone and shale with many thin layers of greenish white siltstone and occasional zones of gray sandstone, some of which is fairly coarse-grained.

The lower two gray units are much like the Carmel formation of the San Rafael group. The third unit, which is the most obvious lithologic type in the Arapien shale of central Utah, is similar to parts of the Carmel at places. The red shale of the fourth unit is unusual among Jurassic rocks of the general region. The uppermost beds are like the thin-bedded red beds common in the older Mesozoic rocks of the Colorado Plateau, and indeed are very similar to the Summerville formation, the uppermost unit in the San Rafael group. In parts of the area these strata recall the Entrada sandstone of eastern Utah. These lithologic similarities give good reason to infer probable equivalence of the Arapien shale with the San Rafael group, but the agreement is not sufficient to justify using the San Rafael formational names.

As they appear in some parts of the region, for example in Arapien Valley and vicinity, these distinctive lithologic types invite division of the Arapien shale into members, but the attempt to trace or recognize them regionally has yielded nothing but uncertainty except for the uppermost unit, which is consistently present wherever the formation has been recognized. This uppermost unit is here set apart as the Twist Gulch member. It is defined as comprising the strata exposed on the north side of Salina Canyon above Twist Gulch and lying between the compact red salt-bearing shale of Twist Gulch and the diverse strata of the Morrison (?) formation.

The basal limestone of the Arapien shale is present near Thistle, near Nephi, and on the west side of the Gunnison Plateau, but in the Sevier Valley no limestone has been seen. As the base of the formation has not been recognized in the Sevier Valley, the lowermost strata may be present though not exposed, but the extent and diversity of the outcrops suggest that not much of the formation is concealed. The thin-bedded gray shale, unit 2 of the foregoing list, appears to be the basal part of the formation in much of the country around Arapien Valley, but to the north and west, gray shale of this type is underlain by the blotched gypsiferous shale, unit 3 , and it is difficult to make out any regular order of occurrence, partly because of the intricate structure. In the belt between the mouth of Salina Canyon and the southern end of Sanpete Valley, for example, some transverse sections suggest anticlinal structure, with basal gray thin-bedded shale in the center of the belt, but others give no evidence of anything but direct succession of beds in descending order westward. In such sections the lowermost unit exposed is the prominent belt of dark red salt-bearing shale that extends from south of Salina to the mouth of the valley of Twelvemile Creek, east of Gunnison. On the theory of anticlinal structure this salt-bearing shale might be interpreted as equivalent to the salt shale of Twist Gulch, although it is much thicker and more saliferous. Northeast of Salina in the foothills of the Wasatch Plateau gray shale of type 2 is interlayered with the dark red of the outer belt, in a position that seems, as far as the structure has been made out, logically basal. The common physical criteria for recognition of top and bottom of strata, applied where outcrops permit, give scattered accurate determinations of position, but when assembled these data afford no positive general result.

7 Eardley, A. J., op. cit 
The writer's present inclination is to consider the saltbearing shale near Salina as basal, followed upward successively by blotched gypsiferous shale and more red salt-bearing shale overlain by the Twist Gulch member. This sequence of strata is grouped together in one member, here named the Twelvemile Canyon member because the outcrops in the valley of Twelvemile Creek west of Arapien Valley include all the distinctive lithologic types, if not a full section of the strata.

Characteristic outcrops of the gray and blotched shales of the Twelvemile Canyon member are shown on plate 18 .

The thickness of the Arapien shale is difficult to estimate but is probably more than 10,000 feet. The Twist Gulch member is measurable with fair precision in Salina Canyon, but elsewhere the intricate contortion of the strata prevents certain measurement. Many outcrops of the softer shale are so covered by products of weathering that observation of attitude is impossible, and even digging to fresh rock does not often help; the homogeneity of the shale and the obscurity of bedding planes usually defeat recognition of structure.

The Twist Gulch member is about 3,000 feet thick in Salina Canyon, as measured by plane table. This thickness, although accurate for the strata measured, is arbitrary in that the Twist Gulch member grades downward into the salt-bearing shale of the Twelvemile Canyon member, and no definite boundary exists. Most of the uncertainty as to the thickness of the formation attaches to the Twelvemile Canyon member. Conservative estimates based on the assumption of modified anticlinal structure for the belt northeast of Salina range between 5,000 and 7,000 feet. On the other hand, if the section is more or less continuous and the beds are not arched in a major anticline, estimates based on different measurements indicate a thickness between 9,000 and 10,000 feet. The actual thickness may lie between these extremes, although the writer is inclined to favor the higher figures rather than the lower. For the exposures on Salt Creek south of Mount Nebo, Eardley ${ }^{1.8}$ gives three different sets of figures, ranging in extreme between 3,000 and 11,000 feet.

\section{AGE AND CORRELATION}

Fossils have been found so far only in the gray unit of the lower member (unit 2 of page 124), and these, in preliminary examination, are assigned by J. B. Reeside, Jr., to an Upper Jurassic age. They are most like forms in the Carmel formation of the San Rafael group. The forms present are: Pentacrinus asteriscus Meek and Hayden, Ostrea strigilecula White, Trigonia aff. T. quadrangularis Hall and Whitfield, Camptonectes cf. $C$. extenuatus Meek and Hayden, Camptonectes cf. $C$. stygius White, Volsella subimbricata Meek, and Lyosoma $\mathrm{sp}$.

The red salt- and gypsum-bearing shale is unfossiliferous, as is also the Twist Gulch member. Generalized correlation of the Arapien shale with the San Rafael group and the Twin Creek limestone of the Wasatch Mountains is briefly discussed in the foregoing section on regional nomenclature.

\section{MORRISON (?) FORMATION}

Above the marine Jurassic and beneath the marine Colorado in the Salina Canyon section and in the section east of Thistle, there is a succession of variegated shales, sandstones, and conglomerates. In an earlier paper ${ }^{19}$ these beds of the Salina and Thistle districts were mentioned as possibly Morrison, and in later field work the writer came to regard them as Morrison. No fossils have been found in the beds, and identification was based on their stratigraphic position and lithologic character. However, now that the same lithologic character is known to be common in the Indianola group, which constitutes the western facies of the basal Upper Cretaceous, the correlation of the beds of the Salina and Thistle districts is much less certain, and they are here designated as the Morrison (?) formation.

In the Salina district the unit is about 1,300 feet thick and consists of variegated shale, red, pink, and violet, commonly blotched with yellow; gray, greenish-gray, and ochre shale; brown, gray, and white sandstone; and conglomerate containing many-colored pebbles of chert and quartzite, whose maximum size is between 2 and 4 inches. In the Thistle district the lithologic character is similar, and the unit is somewhat thicker. The thickness is not exactly known, owing to conditions of outcrop and changes in dip, but it is probably about 1,800 feet. Elsewhere in the western part of the Wasatch Plateau and in adjacent valleys no strata have ever been assigned to the Morrison formation, but it is possible that some of the conglomerates and red beds included in the Indianola group (undifferentiated) are the same as the unit here designated Morrison (?).

No fossils having been found, the local evidence comprises facts of lithology and stratigraphic position. The beds in question are in the approximate stratigraphic position regionally occupied by the Morrison formation. In addition to the general Morrison-like aspect of the beds, lithologic evidence on the question includes three outstanding facts. First, the conglomerates of the unit in Salina Canyon contain notable quantities of black, green, and brown chert, a mineral that is distinctive in the Morrison conglomerates of the northern San Rafael Swell, whereas the Indianola conglomerates as a whole contain little or no chert. Second, the contact between these beds and the underlying Arapien shale in Salina Canyon, the only place in the Wasatch Plateau where it is exposed, is by no means clear-cut, but rather suggests intertonguing; above the first few feet of yellow sandstone, ochre shale, and conglomerate are thin-bedded red and gray shales just like those of the Arapien. 'Third, the variety and succession of the beds in Salina Canyon are not exactly like those of the Indianola; this unit contains no fresh-water limestone, and the variegated beds are notably paler, more delicate in tint, than those of the lower part of the Indianola in districts to the north.

In the Salina Canyon section not only is the basal boundary of Morrison (?) indefinite, but its upper limit is likewise difficult to determine; and the same is true in lesser degree of the relations on Lake Fork near Thistle. A boundary has been drawn at the line of greatest apparent change between the colored rocks of Morrison aspect and the dominantly buff and gray rocks of the type common in the regional Upper Cretaceous, but there is no clear-cut line of division. Furthermore, in the Salina Canyon section ochre sandstones and tinted beds exactly like those common in the Morrison (?) formation appear above the lowest fossil-bearing beds of Colorado age, and such lithologic distinction as

${ }_{19}^{18}$ Eardley, A. J., op. cit., pp. 310, 330, 331.

${ }^{19}$ Spieker, E. M., and Reeside, J. B., Jr., Upper Cretaceous shore line in Utah: Geol. Soc. America Bull., vol. 37, p. 432, 1926. 
these types of strata might be thought to have is apparently of little or no significance.

As to regional evidence, the Morrison formation has been widely recognized in the Colorado Plateaus east of the Wasatch Plateau, and existing knowledge of it has been ably summarized by Baker, Dane, and Reeside. ${ }^{20}$ The isopach map presented by these authors shows the formation thinning rapidly in central-southern Utah toward a western limit which, projected northward, would fall west of the area here considered. East of the Wasatch Plateau the Morrison thickens toward the northeast to a known maximum of 847 feet, but in the entire distribution of the formation across eastern Utah there is no suggestion of thickening toward the Salina area, where the thickness of the unit in question is greater than any so far recorded for the Morrison in the general region.

More important than the mere distribution of the beds, in the present search for information, is the question of the source and direction of distribution of the Morrison sediments. If the source were the same as that of the underlying marine Jurassic sediments, dominantly to the west, it would seem that the formation ought to have been deposited in the belt west of Castle Valley, where the thickest section recorded for the Colorado Plateaus is present. ${ }^{21}$ The conglomerates of the formation in Castle Valley, in a normal distribution of such sediments, should continue westward, toward the source; complete bypassing of gravels across such destructible material as the marine Jurassic sediments is difficult to visualize without more evidence of erosion than appears between the Arapien shale and the Morrison (?), for example, of the Salina district. Published accounts of the formation in the Colorado Plateaus contain no conclusions as to its source and distribution. Evidence known to the writer suggests a western or northwestern source, but this is not well enough worked out to justify discussion.

Review of this evidence leads to no satisfactory conclusion, but at present the facts in favor of identification as Morrison seem to outweigh somewhat the opposing facts, and rather than adopt an alternative nomenclature which would appear to deny the presence of the formation in the region, it seems best to designate the beds by the qualified term Morrison (?).

\section{CRETACEOUS SYSTEM}

GENERAL CHARACTER AND DISTRIBUTION

Rocks of Upper Cretaceous age are extensively exposed in central Utah. They occupy large parts of the surface in the Wasatch and Gunnison Plateaus and in the Cedar Hills, as well as in the valleys adjacent to these higher lands. Although the exposures are by'no means continuous, most of the higher formations can be traced across the area with little interruption, and in general the conditions for the determination of stratigraphic relationships are favorable.

The rocks are dominantly clastic, and in general they are finer-grained on the east and coarser-grained on the west, a natural result of their derivation from high land masses to the west. They are divisible into two major groups. The lower group includes the Mancos shale and the Star Point and Blackhawk formations in the eastern part of the area and the Indianola group in the western part. (See fig. 15.) The upper group includes the Price River formation and part of the North Horn formation. These two major groups are separated by the unconformity that resulted from the main folding of the Wasatch Mountains-an angular unconformity in the western part of the area and a disconformity in the eastern part. As a rule, the lower unit is composed of marine beds that grade upward to continental beds, the whole dominantly buff and gray in color; the upper unit, in central Utah, is almost exclusively continental in origin and contains noteworthy amounts of varicolored beds in the upper part. Notable exceptions are the abundance of coarse continental sediments and red beds in the lower unit of the westernmost part of the area, and the presence in the lower part of the upper unit of thin brackish-water beds, but on the whole the two units are distinct as to the features named.

INDIANOLA GROUP

\section{DEFINITION AND NOMENCLATURE}

In the western part of the Wasatch Plateau the rocks of Colorado age form a heterogeneous assemblage of conglomerate, sandstone, shale, and limestone, of both marine and continental origin, showing a wide range in color and, in parts of the region, abrupt lateral change between extremes in rock types. These strata, without exception, occur within isolated areas in the folded belt at the western base of the plateau, and correlation between the different areas has involved a group of problems whose general nature is outlined in the first part of this report. Because of the significance in the regional geology of the correlations now established, it is desirable to make clear those elements of the field evidence on which the conclusions are mainly based.

Marine strata of Colorado age have long been recognized at three localities on the western border of the Wasatch Plateau-Salina Canyon, Sixmile Canyon, and Lake Fork east of Thistle. These strata are of the lithologic type normal for the Upper Cretaceous of the Colorado Plateaus and adjacent regions to the eastgray, buff, and brown sandstones and shales, with some conglomerate-and in the present study they were found to be subdivisible into definite lithologic units that parallel, at least approximately, the major faunal divisions of the Colorado. In all three localities they underlie younger strata in angular unconformity.

In Sixmile Canyon and on Lake Fork the lowest formation above the unconformity is a conglomerate, for merly classified as the basal conglomerate of the Wasatch formation but now identified as the Price River formation. At three localities within a radius of 4 miles north of Indianola this same conglomerate overlies, in angular unconformity, another conglomeratic assemblage of rocks that contains prominent units of brilliantly colored shales and sandstones, with some fresh-water limestone. At the three areas in the Indianola district the strata are different, as described farther on, and the only characteristic they have in common is their occurrence beneath the conglomerate at the base of the Price River formation, which may be traced through the district with slight chance of error.

At the northernmost of these outcrops, on Dry Creek, a sandstone at the top of the section there exposed contains Corbula nematophora, a member of the Colorado fauna. Although local proof is lacking, regional evidence shows that this sandstone is stratigraphically a

\footnotetext{
${ }^{20}$ Baker, A. A., Dane, C. H., and Reeside, J. B., Jr., op. eit., pp. 9, 47, 55. fig. 14 .

ames, and Reeside, J. B., Jr., Sedimentary rocks of the Stan Rafael Swell and some adjacent areas in eastern Utah: U. S. Geol.
} Survey Prof. Paper 150, pp. 81, 91-92, 1928. 
part of the variegated sequence on Hjork Creek, to the south. In the east front of the Gunnison Plateau the Price River conglomerates may be recognized, with the North Horn and Flagstaff formations in characteristic development above. Beneath the Price River, in angular unconformity (see fig. 16) is the same sort of lithologic assemblage as in the Indianola district, lacking only marine beds, as far as is known from reconnaissance observation. This belt of outcrop may be traced southward, with some interruptions, into the foothills of the Wasatch Plateau northeast of Salina, where again the strongly colored shales, conglomerates and freshwater limestones are only $31 / 2$ miles from the buff and gray marine Colorado in Salina Canyon. The same strata may be recognized also on the west side of the Gunnison Plateau, where the angular discordance with the overlying Price River is slight, but the succession otherwise is similar to that of the east front. Traced northward, these strata are continuous as far as the Cedar Hills, where Schoff ${ }^{22}$ has found them to contain a marine zone with a diagnostic Colorado fauna. The section in the Cedar Hills is very thick and, although parts of it are not well exposed, the marine zone is clearly intercalated between conglomerate and red-bed facies that are continuous with the beds in the Gunnison Plateau. There remains to be closed only the gap between the Cedar Hills and the Indianola district, where the nearest outcrops are 8 miles apart. The sum of the facts outlined above leaves little room for doubt that the beds of the Indianola district are equivalent to those in the Cedar Hills and hence to the others in all the above-mentioned districts bordering Sanpete and Sevier Valleys.

The apparently incongruous assemblages in these several sections are thus brought together in a single gross unit. In the Thistle, Sixmile, and Salina Canyon areas this unit, truncated by the Price River and younger formations, is clearly divisible into the San pete, Allen Valley, Funk Valley, and Sixmile Canyon formations, but in the Indianola district, in the area between Salina and Gunnison, in the Gunnison Plateau, and in the Cedar Hills such units as now seem differentiable fail to correspond well enough with the formations of the other districts to justify a named subdivision. The writer therefore proposes that the entire unit be called the Indianola group, subdivided into formations where consistently possible, undifferentiated where not. (See pl. 19, A.) The Indianola district, which is designated as the type area, contains representatives of all three major lithologic types now known in the Upper Cretaceous of the region-(1) buff and gray marine beds, on Dry Creek about 41/2 miles north of Indianola, (2) buff and gray continental beds on Little Cleảr Creek about 2 miles northeast of Indianola, and (3) conglomerate, variegated beds, and freshwater limestone on Hjork Creek about 3 miles north of Indianola. The lower conglomerates on Hjork Creek, in the Gunnison Plateau, in the Cedar Hills, and in the foothills northeast of Salina are thought to be roughly equivalent to the Sanpete formation, and they may also be equivalent to the strata in Salina Canyon and near Thistle, which, however, have been described as Morrison (?) formation. The marine zone on Dry Creek and in the Cedar Hills probably correlates with the Funk Valley formation. The upper conglomerates of the Cedar Hills and the Gunnison Plateau and the buff beds on Little Clear Creek probably represent the Sixmile Canyon formation.

\section{SANPETE FORMATION}

The basal rocks of the Indianola group in parts of the western marginal belt form a distinct unit of sandstone and conglomerate, with minor amounts of shale, containing fossils of lower Colorado age. This unit overlies the Morrison (?) formation and underlies the Allen Valley shale. Where clearly differentiable, it is set apart as the Sanpete formation, named from Sanpete Valley, on the east side of which, south of Manti, the rocks of the formation are exposed in hogbacks and low ridges. The formation is exposed also in $\mathrm{Sa}$ lina Canyon about 4 miles east of Salina and in the canyon of Lake Fork about $1 \frac{1}{2}$ miles southeast of Thistle. Equivalent strata occur in the lower part of the Indianola group (undifferentiated).

The only one of the three localities that affords a complete and well-exposed section of the formation is Salina Canyon, where it is about 1,350 feet thick. This figure is given as approximate because of the difficulty in determining a reasonable boundary between the Sanpete and Morrison (?) formations, as discussed on page 125. The lower 335 feet of the formation as here specified may belong with the Morrison (?). The top of the Sanpete formation is exposed at the type locality and in Salina Canyon, and it is easily defined.

The formation consists of brown, ochre, buff, and gray sandstone, gray to ochre shale, mainly sandy, and gray conglomerate. Conglomerate is fairly abundant in the lower part but absent in the upper part. Fossils have been found in the upper part only in Salina Canyon, where the lowest fossiliferous zone is about 90 feet below the top of the formation, but near Thistle fossils are abundant in the lower part, which is there less conglomeratic.

On the east strata equivalent to the Sanpete formation comprise the basal unit of the Mancos shale, which in Castle Valley ${ }^{23}$ is dark-gray marine shale, and possibly also the Dakota (?) sandstone. The formation represents a near-shore zone of dominantly coarse sediments intermediate between the open sea to the east and a mountain-front belt of coarse gravel fans to the west. A similar facies, but not so coarse, has been recognized in the Coalville district, ${ }^{24}$ to the northeast, and in the Kolob Plateau, ${ }^{25}$ to the southwest.

\section{ALLEN VALLEY SHALE}

Between the sandstones of the Sanpete and Funk Valley formations is a body of marine shale, 600 to 800 feet thick, here designated the Allen Valley shale. The type locality is at the base of the Wasatch Plateau, in Allen Valley, a narrow longitudinal valley separated from Sanpete Valley by a pronounced hogback of Sanpete formation, about 3 miles southwest of Manti. Most of the outcrop in this area is thinly covered by soil, but a good exposure of the entire formation is afforded by an irrigation ditch in the $\mathrm{SW}^{1} / 4$ sec. 26 , T. 18 S., R. 2 E., Salt Lake meridian, near the head of Allen Valley. The structural position of the Allen Valley shale in Sixmile Canyon is shown in figure 17. The only other outcrop of the formation known in central Utah is in Salina Canyon, where it is partly

${ }^{22}$ Schoff, S. L.. Geology of the Cedar Hills, Utah (unpublished notes). ${ }^{23}$ Lupton, C. T., Geology and coal resources of Castle Valley in Carbon, Emery, and Sevier Counties, Utah: U. S. Geol. Survey Bull. 628, p. 26 , 1916.

${ }^{24}$ Wegemann, C. H., The Coalville coal field, Utah : U. S. Geol. Survey Bull. 581 , p. 163,1915

${ }^{25}$ Richardson, G. B3., The Upper Cretaceous section in the Colob Pla teau, southwestern Utah: Wash. Acad. Sci. Jour., vol. 17, pp. 464-475. 
exposed in a narrow strip on the north side of the canyon about 5 miles east of Salina; there the top and base are well exposed.

The Allen Valley shale is fairly uniform in general aspect; it consists largely of evenly bedded gray marine shale of the type common in the regional Upper Cretaceous. In detail it exhibits some variety; the shale is interbedded with thin layers of yellowish bentonite, siltstone, very fine-grained sandstone, and gray limestone. No individual bed is more than a foot thick. The shale ranges in texture from impalpable to very sandy. At the type locality the formation is 620 feet thick, and in Salina Canyon it is 850 feet thick.

Fossils from the Allen Valley shale, identified by J. B. Reeside, Jr., are of middle Colorado (Carlile) age, and indicate that the formation is to be correlated with the Ferron sandstone, a member of the Mancos shale in Castle Valley. ${ }^{26}$ This indicates an embayment of the Mancos sea west of the peninsular land and shoal area in which the Ferron was deposited. Shale of the same age has been found in the Coalville region, and in southwestern Utah; ${ }^{27}$ it is not unlikely that the formation is widespread in a belt trending a little east of north through central Utah.

\section{FUNK VALLEY FORMATION}

The Allen Valley shale is overlain by marine sandstone and shale of Niobrara age, which form a unit about 2,250 feet thick, here named the Funk Valley formation. The type locality is in the ridges bordering Funk Valley, in secs. 34 and 35, T. 18 S., R. 2 E., Salt Lake meridian, 3 to 4 miles southwest of Manti. (See pl. 19,B.) The formation is exposed more extensively than the others of the Indianola group in the Manti area; it forms the marginal foothills of the Wasatch Plateau for more than 4 miles south of Crystal Spring. In Salina Canyon the basal 600 feet of the formation is exposed. In the Cedar Hills, just east of the southern Wasatch Mountains, Schoff ${ }^{28}$ has found marine sandstones that are probably equivalent to part of the Funk Valley formation. Nonmarine strata of the same age are probably abundant and widespread in the Indianola group (undifferentiated).

At the type locality the formation consists of three clearly separable members: (1) a basal series of sandstones with thin interbedded shale, about 900 feet thick; (2) a middle unit of gray marine shale, 650 feet thick; and (3) an upper sandstone 700 feet thick. The sandstones range in color from white through cream and buff to brown. The position of the formation in the Sixmile Canyon section is shown in figure 17.

Fossils from the two sandstone members are of Colorado age, substantiating the natural inference from stratigraphic relations that the Funk Valley formation is equivalent to the part of the Mancos shale immediately above the Ferron sandstone member in Castle Valley. Like the Allen Valley shale, the Funk Valley formation has counterparts in both the CoalvilleEvanston and Kaiparowits-Kolob regions, but correlation over the rather long stretch between these areas is not yet precise enough to justify extension of nomenclature.

\section{SIXMILE CANYON FORMATION}

In Sixmile Canyon east of the Funk Valley formation is a thick succession of coarse-grained gray sandstone and conglomerate containing a coal-bearing member of finer grain. To this succession the name Sixmile Canyon formation is here applied. This unit has not been recognized at any other place in the Wasatch Plateau, but, like the underlying formations of the Indianola group, it is probably represented at some localities where the group is not subdivisible. In Sixmile Canyon three members are recognizable-(1) a prominent gray conglomeratic sandstone about 2,000 feet thick; (2) a coalbearing member containing gray to cream-colored and white mainly fine-grained sandstone, gray to white shale, carbonaceous shale, and coal, about 300 feet thick; and (3) an upper member of conglomerate and conglomeratic sandstone of which 425 feet is exposed. The top of the formation has not been seen; the uppermost strata in the section measured are the highest beds exposed under the lower angular unconformity in Sixmile Canyon. (See fig. 17.)

Until 1935 the strata now assigned to the Sixmile Canyon were thought to be late Montana in age and were correlated with the Price River formation. ${ }^{29}$ In 1935 and 1936 fossil plants and mollusks collected from the coal-bearing member were determined by $R$. W. Brown and J. B. Reeside, Jr., to be of Colorado age. This fixes the age of the lower member as Colorado. The upper member has yielded no fossils and its age is not proved, but it is similar for the most part to the lower member and is apparently not separated from the middle member by any break other than the change in lithology, which is itself not sharp; it is therefore provisionally included with the underlying beds and interpreted to be of Colorado age. It might possibly be of early to middle Montana age, but not late Montana, because rocks of that age overlie the angular unconformity.

The change in age assignment of this formation has resulted in a new interpretation of the late Montana stratigraphy and the orogenic history of central Utah, as is brought out in the parts of this report-devoted to those subjects. It has also brought the coal-bearing member of the Sixmile Canyon formation into closer coordination than before with the regional pattern of coal occurrences. Westward and southwestward across Utah the coal-bearing rocks of the Upper Cretaceous appear at successively lower levels; the coal beds of the eastern Book Cliffs are of late Montana age, those of the Wasatch Plateau of middle Montana, and those of Castle Valley and southern Utah of Colorado age. In the main body of the Wasatch Plateau the strata of late Montana age contain no coal. Considered as late Montana the coal of the Sixmile Canyon formation was somewhat incongruous in this scheme; as late Colorado it is in better accord.

\section{INDIANOLA GROUP (UNDIFFERENTIATED)}

The discussion of the Indianola group thus far presented has necessarily brought out many of the important characteristics of the unit for those areas where it is not differentiated. There need be added here only

\footnotetext{
${ }^{26}$ Spieker, E. M., and Reeside, J. B., Jr., Upper Cretaceous shore line in Utah : Geol. Soc. America Bull., vol. 37, pp. 432-435, 1926.

${ }^{27}$ Wegemann, C. H., The Coalville coal field, Utah: U. S. Geol. Survey Bull. 581, pp. 161-184, 1915. Richardson, G. B., Reconnaissance of the Jr., in Gregory, H. E., and Moore, R. C., The Kaiparowits region: U. S. Gr., in Gregory, Survey Prof. Paper 164, n. 113. 1931 . 28 Schoff, S. L., Geology of the Cedar Hills, Utah (unpublished notes). 28 Spieker, E. M., and Reeside, J. B., Jr., Upper Cretaceous shore line in Utah : Geol. Soc. America Bull,, vol. 37, p. 433, 1926. Richardson, G. B., Coal in Sanpete County, Utah : U. S. Geol. Survey Bull. 285, p. 281, U. S. Geol. Survey Water-Supply Paper 199, p. 9, 1907.
} 


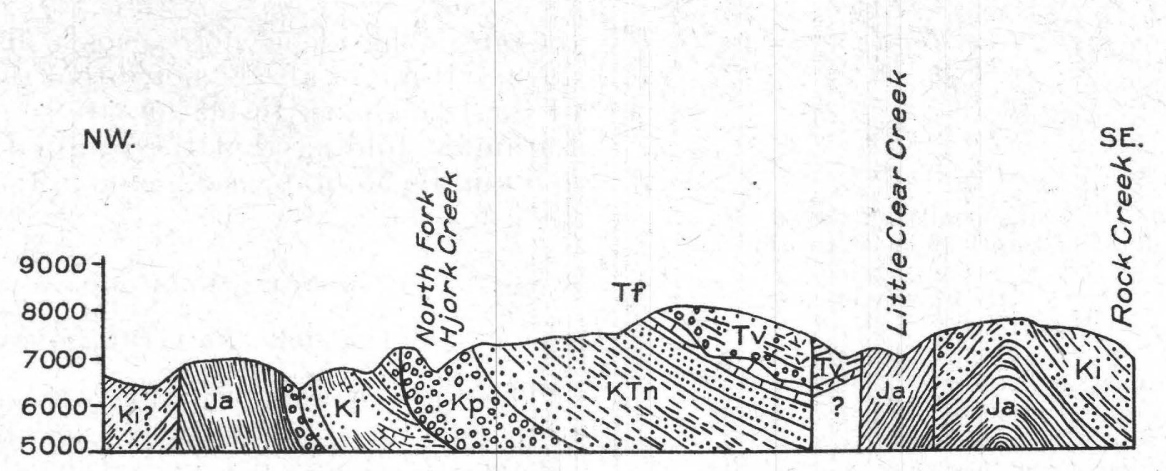

Section north of Hjork Creek and across divide to Little Clear Creek

A

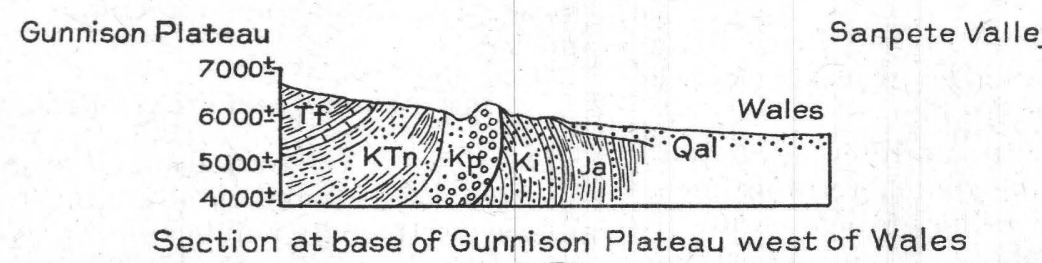

B

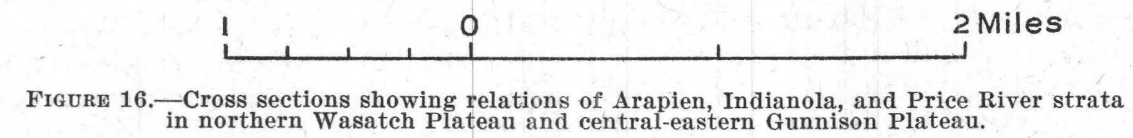

Qal. Alluvium.

Tv. Volcanic rocks of uncertain age, possibly mid-Tertiary.

a somewhat more specific description of lithology and a brief discussion of age.

The three facies of the Indianola-buff and gray marine, buff and gray continental, and red-bed continental-are exposed in Dry Creek, Little Clear Creek, and Hjork Canyons. (See p. 127.) These three localities are separated by faults, in an area of rather complex structure (see fig. 16), and it is impossible to work out a completely connected section among them. The main outlines of the section, however, seem fairly clear. On Hjork Creek beneath the angular unconformity are about 2,000 feet of strata in contact, probably sedimentary, with the Arapien shale; these beds probably represent the lower part of the Indianola there. On Dry Creek are conglomerates and sandstones, probably between 2,000 and 3,000 feet thick, with a marine zone at the top that is estimated to be about 7,000 to 8,000 feet above the basal beds of Hjork Creek. This total is similar to the thickness of the group in Sixmile Canyon, and it may represent most of the unit in the Indianola district; but 15 miles to the southwest, in the Cedar Hills, Schoff ${ }^{30}$ has found nearly 15,000 feet of strata that seem to belong to the Indianola group, and it is probable that the section north of Indianola is incomplete.
KTn. North Horn formation. Kp. Price River formation. Ki. Indianola group.

On the ridge east of Little Clear Creek is a considerable area of Indianola strata whose stratigraphic relations are not entirely clear. They are mainly buff and brown sandstone and conglomerate with gray shale, and they differ strongly from the beds on Hjork Creek, although they are similar to some of the beds on Dry Creek. As the structure is now interpreted, some of the strata in this outcrop seem to belong in the lower part of the Indianola group, but some appear to underlie the Price River in structural position, which suggests that they are in the upper part. Neither the apparent thickness nor the lithologic aspect of the beds agrees with the hypothesis that the entire group is present. All that can now be said is that the strata east of Little Clear Creek belong in the Indianola group, but their precise position is undetermined.

The strata on Hjork Creek represent well the conglomerate-variegated bed facies of the group; and to give some idea of the lithologic types in this aggregate, which is the only facies of the three not elsewhere described, the following roughly grouped section is offered.

\footnotetext{
${ }^{30}$ Schoff, S. L., Geology of the Cedar Hills, Utah (unpublished notes).
} 
Section of Indiunola strata exposed on Hjork Creek, sec. 21, $T$. 11 S., $R .4$ E., Salt Lake Meridian

Price River formation.

Angular unconformity.

Indianola group :

1. Sandstone, cream to buff, medium-grained to slightly conglomeratic, interbedded with shale, red, sandy

2. Shale, deep red to gray, with interbedded sandstone, brown, medium-grained

3. Conglomerate, gray to reci, pebbles and boulders of quartżite and limestone, average 4 inches but many are more than 1 foot in diameter; some interbedded red sandstone and shale

4. Shale, sandstone, and conglomerate, brilliantly colored in various shades of red and purple; limestone, gray to white; sandstone, gray, fine, calcareous

5. Sandstone, brown to buff; conglomerate; shale, dark gray

6. Shale, orange, vermilion, maroon, gray; sandstone, brown to gray; conglomerate and limestone in irregular beds

7. Conglomerate, brown to gray; interbedded red Arapien shale. andstone and shale; gray shale

The contact between the Indianola and Price River units is shown in plate $21, B$, and the general relations on Hjork Creek are shown in figure 16.

The age of the Indianola group (undifferentiated) is only partly known. The marine zone heretofore mentioned as containing fossils of Colorado age occurs in the upper part of the unit, and the age of the underlying strata is not definitely known. Among the areas where the group has not been subdivided the marine zone has been recognized at two places only-on Dry Creek, where it is the uppermost unit exposed, and in the Cedar Hills, where it is about 2,500 feet thick. The base of the marine zone is about 9,400 feet above the base of the group and its top is about 2,800 feet beneath the angular unconformity at the locality of maximum known thickness. ${ }^{31}$ At both these places there is no evident basis for setting off the lower beds, and where the marine zone has not been recognized the whole thickness identified as Indianola, heterogeneous though it is, seems to make a fairly consistent unit. For these reasons the beds below the marine zone are included with it, and the whole is regarded tentatively as upper Cretaceous in age.

\section{ROCKS OF EARLY AND MIDDLE MONTANA AGE}

On the west side of the Wasatch Plateau no rocks definitely identified as equivalent to the upper part of the Mancos shale and the Star Point are exposed. The Blackhawk formation, of middle Montana age, is exposed east of Mount Pleasant, on Twelvemile Creek, the next creek south of Sixmile, and in Salina Canyon, ${ }^{32}$ and at all these places it is similar to the typical Blackhawk of the east front of the plateau. It is unnecessary, therefore, to describe it here, but attention may be directed to the fact that the westernmost Blackhawk rocks exposed are no coarser in grain than those to the east. This suggests that by middle Montana time the highlands from which the coarse sediments of Colorado age were derived had been worn down. The total thickness of the Blackhawk formation in the western belt is not known, but zones of the formation have been tentatively recognized in the records of borings, which suggest that the formation is not much, if any, thicker than in the Pleasant Valley district and west of Huntington Canyon. ${ }^{33}$ It seems likely that by middle Montana time the rate of subsidence in the geosynclinal belt had slowed down. It might also be noted that the western outcrops of the Blackhawk formation are so close to the belt of Laramide folding that the original presence of early and middle Montana sediments in the folded belt seems almost certain.

\section{PRICE RIVER FORMATION}

\section{DEFINITION AND LITHOLOGIC CHARACTER}

The Price River formation was originally defined ${ }^{34}$ to include the strata in Price Canyon above Castlegate between the Blackhawk formation and the former lower member of the Wasatch formation, now the North Horn formation. It consists there mainly of medium- to coarse-grained sandstone, with some grit and conglomerate and a minor amount of shale, and is divided into two members. The Castlegate sandstone member is separated from the upper member solely because of its cliff-forming habit, which gives it great regional prominence; lithologically the two members are closely similar. In Price Canyon the formation is about 1,100 feet thick. The lithologic character is shown in plates 20 and 21 .

\section{DISTRIBUTION AND STRATIGRAPHIC RELATIONS}

The Price River formation crops out throughout the Wasatch Plateau and in adjoining regions to the west and east. Its most notable known extension outside of central Utah is in the Book Cliffs, where the Castlegate sandstone member is recognizable as far east as the Utah-Colorado boundary.

In the eastern part of the Wasatch Plateau the Castlegate sandstone overlies the Blackhawk formation without trace of angular discordance, but in many places where the contact is exposed there is evidence of disconformity; the Castlegate was deposited on an erosion surface of very low relief cut into the uppermost Blackhawk rocks. This disconformity was interpreted originally to mean hiatus ${ }^{35}$ and probably also disturbance somewhere to the west, although at the time it was not thought to represent the main folding of the Wasatch Mountains. The contact, even though erosional, appeared too uniform in the eastern Wasatch Plateau and the Book Cliffs to signify profound or extensive erosion. On the other hand, the change in sediments between Blackhawk and Castlegate, and especially the sharpness with which coarse sands and grits appear above the contact, evidently signifies a notable change in the physiography of the source area.

The upper limit of the Price River formation has always been difficult to set, because the coarse-grained gray sandstones grade upward into and interfinger with the variegated beds distinctive of the North Horn formation of the eastern part of the Wasatch Plateau. In earlier stages of the study, when this contact was supposed to mark the passage from Cretaceous to Eocene, and especially the considerable hiatus intervening

${ }^{31}$ Schoff, S. L., Geology of the Cedar Hills, Utah (unpublished notes). 32 Spieker, Salina Canyon district, Utah : U. S. Geol. Survey Bull. 796, pp. 137-139, 1928.

${ }^{33}$ Spieker, E. M., The Wasatch Plateau coal field, Utah : U. S. Geol. Survey Bull. 819, pp. 81, 89-90, 1931. Through an error which escaped notice in proofreading, the thickness of the Blackhawk formation is stated on p. $27-28$ of spleker's report to range between feet (31) the formation may be even more than 1,500 feet thick (see pl. 31) the formation may be even more than 1,500 feet thick. mations of the Wasatch Plateau, Utah: Geol. Soc. America Bull., vol. 36,

p. ${ }_{35}^{45,}$ Spieker, E. M., and Reeside, J. B., Jr., op. cit., pp. $445-447$, fig 3. 
between the late Montana and the Wasatch, it appeared to present a serious problem. However, now that the lower North Horn strata are known to be late Cretaceous, the lack of a clear-cut boundary not only involves no difficulty but is seen rather to indicate the normal unbroken progression from postorogenic gravels and sands to colored muds and fresh-water limestones, with less sand, and finer, as the plain of aggradation was built up and the highland source was worn down. The boundary as now drawn is purely lithologic and is placed at the horizon of greatest change between the sandstone and conglomerate of the Price River and the variegated and other beds of the North Horn. In general it is not difficult to recognize, and at places such as North Horn Mountain there is notable contrast between the sandstones of the Price River and those intercalated in the North Horn, which are much lighter in hue. In the western belt, however, where the Price River is very coarse-grained and overlaps the old foothill togography of the late Cretaceous mountains, there are localities where it is difficult to distinguish from the North Horn strata.

The contact between the Price River and North Horn formations is not at the same horizon throughout the region. In places, such as Joe's Valley, it can be seen in general view to rise in the section. In any given section this change records the shifting, at that place, of the margin between the lateral belt of coarse materials on the west and the belt of finer materials on the east. This margin, or zone of transition, between the two belts migrated westward, in the main, as the source area was worn down, and in consequence the boundary between the two formations doubtless migrates stratigraphically upward toward the west. Farther east it may be more stable or may even rise.

\section{AGE}

The age of the Price River formation is definitely fixed, at least for the lower part, as Montana, and it probably is late Montana. Fossils already listed from the Castlegate sandstone member ${ }^{36}$ place it as probably equivalent to the Fruitland and Kirtland formations of the San Juan region and other late Montana formations of the Colorado Plateau and adjacent mountains. ${ }^{37}$ Furthermore, the Castlegate, in its eastward extension along the Book Cliffs, changes gradually to a huge tongue of littoral marine sandstone penetrating marine shale, the upper parts of which contain an abundant Montana fauna that is probably not so late in age as the Fox Hills. ${ }^{38}$ The North Horn formation probably is Lance in age, and the upper part of the Price River may also be, but no fossils have yet been found in those beds. The passage from late Montana to Lance probably lies somewhere in the upper member of the Price River formation or perhaps in the lower few hundred feet of the North Horn formation.

\section{REGIONAL RELATIONS AND CORRELATION WESTWARD}

From the type locality, in the Castlegate district, the Price River formation has been traced southward and westward to the Salina Canyon district, thence northward to the Thistle district, and eastward across the northern part of the plateau to the type area. Outcrops are practically continuous across the region, excepting the west flank of the plateau, and there is little doubt of continuity throughout. In most of the plateau the Castlegate sandstone member is recognizable and the formation is fairly uniform in character and stratigraphic relations. In the northwestern part, however, the outcrops on the western border are separated from those in the central belt by a strip of the crest in which the formation is covered by later beds for minimum distances of from 4 to 6 miles and cannot be traced through anywhere. The general stratigraphic relations agree so well, however, that the correlation is made without reservation, especially in consideration of the remarkable uniformity of stratigraphic relations in the large areas through which the beds have been traced without interruption. The possibility of deceptive lateral change in the concealed areas is set aside by the fact that the one important lithologic change, from the twofold sandstone formation of the type section to the single massive conglomerate of the west (described below), is fortunately revealed by continuous areas of outcrop in the central belt near Bennion Creek. (See fig. 14, loc. 3.) The evidence bearing on this correlation is here stressed because of its importance in the conclusions that arise from the correlation of the eastern Price River with the big conglomerate of the west, with respect to the date of the folding in the Wasatch Mountains. In order to make the case absolutely clear, it is well to review certain features of the areal relations in some detail.

From Castlegate westward the Price River rocks may be traced without interruption into the hills east of Pleasant Valley and northeast of Scofield. Between the upper course of Beaver Creek, however, and the canyon of Price River, in the western half of T. 12 S., R. 8 E., Salt Lake meridian, ${ }^{39}$ there is a divide across which the Castlegate sandstone member cannot be traced. On Jump Creek not far west of Beaver Creek the Castlegate seems to disappear westward, as it does also on the south side of the canyon of Price River mentioned above. The sandstone identified as Castlegate on the north side of Price River may be traced northwestward into the unit of undifferentiable sandstones and conglomerates which, thickening and becoming coarser, is the massive postorogenic conglomerate of the Thistle-Indianola district. In the northern part of the Pleasant Valley district the Blackhawk formation is much thicker than it is not far across the divide to the east. These facts might be interpreted to mean that the Castlegate changes westward to finer-grained sediments in the Jump Creek area and becomes there the upper part of the unit mapped as Blackhawk. Under this construction the sandstone on Price River, mentioned above as equivalent to the basal postorogenic rocks to the west identical in appearance with the Castlegate, would nevertheless be higher in the section, above the Price River formation. The writer turned to this interpretation when the presumed Castlegate of the west was shown to be equivalent to the postorogenic conglomerate and the folding was thought to be of age later than Montana, but it is an unnatural interpretation, and was readily abandoned with the theory of post-Montana age for the folding. (See discussion of Sixmile Canyon formation.) Especially is this true in consideration of the widespread unity in the appear-

\footnotetext{
36 Spieker, E. M., and Reeside, J. B., Jr., op. cit., p. 446.

${ }^{37}$ For a summary of the regional correlation see the statement by Reeside in Gregory, $H_{\text {. }}$., and Moore, R. C., op. cit. (Prof. Paper 164), Montana is the Sixmile Canyon sandstone of this paper, now placed in the Colorado). the Colorado).

- The Book Cliffs coal field in Emery and Grand CounS. Geol. Survey Bull. 852, pp. 14-15, 1936.

Spieker, E. M., op. cit. (Bull. 819), pl. 31 .
} 
ance of the Castlegate sandstone in the western part of the plateau and its general similarity to that of the east. The western Castlegate is separated from outcrops of well-authenticated Castlegate in the central part of the plateau by only a few small areas of forested country and fault zones, across which correlation now seems thoroughly valid.

To sum up, although there are gaps in the areal distribution of the basal Price River rocks that prevent absolute demonstration of continuity and might possibly conceal an alternative relationship, the bulk of evidence in favor of continuity is so overwhelming that no other conclusion seems reasonable. The writer correlates the type Price River formation with the postorogenic conglomerate of the western districts, and the disconformity at the base of the Castlegate sandstone with the angular unconformity of the folded belt, thus placing the main Laramide orogeny of central Utah between Blackhawk and Castlegate, or, approximately, middle and late Montana times.

\section{REPRESENTATIVE SECTIONS}

Descriptions of the formation in the type area and other eastern parts of the Wasatch Plateau have already been published, ${ }^{40}$ and are abstracted above sufficiently for present purposes. For the Salina Canyon district, on the southern margin of the plateau where the formation is characteristic and widespread, descriptions also have been published. ${ }^{41}$ In the northwestern part of the plateau, between Indianola and Thistle, the thick conglomerate facies discussed above is present. Here the formation ranges between 1,000 and 2,000 feet in thickness and consists largely of conglomerate which, at its coarsest, contains boulders of quartzite more than 2 feet in diameter. The conglomerate ranges in color from deep red, as in the striking canyon exposures of Red Narrows, east of Thistle, to dull gray, according to the amount of red silt present. The change from red to gray is locally abrupt, as, for example, near Thistle at the mouth of Red Narrows. The conglomerate becomes finer eastward, but it extends as far east as the Pleasant Valley district, where it begins to change definitely to the conglomeratic sandstone facies of the east. A section taken on Bennion Creek is here presented as representative of the unit in the district of transition. This section is not complete and is thus not a record of the thickness of the formation, but it portrays the character of the rocks in the central-northern part of the plateau better than other available sections.

Section of part of Price River formation on Bennion Creek, sec. 14, T. 11 S., R. 6 E., Salt Lake meridian

North Horn formation:

Brown, buff, and gray sandstone, gray to red shale, and limestone conglomerate.

Price River formation:

1. Grit, conglomerate, cross-bedded, weathers Feet creamy buff

2. Grit, much like unit 1 but weathers brown

3. Grit like unit 1

4. Grit like unit 1, gray with layers of green-gray silty sandstone

5. Sandstone, medium to coarse, creamy gray, containing scattered pebbles up to $1 / 2$ inch-

6. Conglomerate, pebbles up to 1 inch in matrix of gray grit

7. Sandstone, gray, medium to fine, irregularly crossbedded, containing locally some gray grit and coarse sandstone, forms massive cliffs and ledges, weathers buff in upper part
8. Conglomerate, gray where fresh, brownish gray to dove gray in distant view; pebbles and boulders up to 1 foot common, occasional larger boulders, well-rounded quartzite and quartzitic sandstone (some containing Fusulina), in matrix of fine to medium light-gray sandstone; massive, forming strong cliffs : 110 feet measured at exact locality of section, base not certain anywhere, but maximum thickness here probably

Total

561

FOSSILS

The Price River rocks are largely unfossiliferous. Finer sediments intercalated with the dominant coarse sandstones and conglomerates of central Utah have yielded a few fossils in the Wasatch Plateau, which have been identified by J. B. Reeside, Jr., as follows:

Unio priscus Meek and Hayden.

Unio cf. U. danae Meek and Hayden.

Sphaerium planum Meek and Hayden.

Modiola regularis Whitfield.

Viviparus panguitchensis White.

Viviparus cf. V. leidyi Meek and Hayden.

Viviparus cf. V. leai Meek and Hayden.

Goniobasis? subtortuosa Meek and Hayden.

Goniobasis cf. G. judithensis Stanton.

Planorbis? sp.

These fossils are considered by Reeside to be characteristic of the late Montana stage in the Upper Cretaceous of the Cordilleran region, an age determination which agrees with the better-established conclusion for the Book Cliffs, where the Castlegate member forms part of a fossiliferous marine section that is clearly of late Montana age.

The conglomerates of the western belt have yielded no fossils, but a sandstone bed above the main conglomerate of the Price River in the Gunnison Plateau near Wales, Utah, has been found to contain the following species, identified by Reeside:

Goniobasis tenuicarinatus Meek and Hayden.

Goniobasis aff. G. nebrascensis Meek and Hayden.

Vitrina aff. V.? obliqua Meek and Hayden.

Viviparus nanus White.

Physa pleuromatis White.

Sphaerium sp.

Bulinus sp.

These fossils are of interest in that they come from the locality where C. A. White collected a number of species that he assigned to the Wasatch formation, and they are cited here principally on that account. The significance of this occurrence is discussed below, in the paragraphs on the North Horn fossils. (See p. 134.) The fossil-bearing beds near Wales may be somewhat younger than the main body of the Price River formation to the east, but as far as the regional stratigraphy is now known they should be Cretaceous.

\section{CRETACEOUS AND TERTIARY SYSTEMS}

\section{NORTH HORN FORMATION}

DEFINITION AND IITHOLOGIC CHARACTER

The lower member of the Wasatch formation as heretofore identified in the Wasatch Plateau ${ }^{42}$ is here redefined as the North Horn formation. The name is derived from the type locality, on North Horn Mountain

40 Spieker, E. M., and Reeside, J. B., Jr., op. cit. (1925), pp. 445-448. Spieker, E. M., op. cit. (Bull. 819), pp. 39-45.

S1 Spieker, E, M., and Baker, A. A., op. cit. (Bull. 796), pp. 135, 139-143.

139-143.
${ }^{2}$ Spieker, E. M., and Reeside, J. B., Jr., op. cit. (1925), p. 448. Spieker, E. M., op. cit. (Bull. 819), pp. 45-48. 
(loc. 4 on fig. 14) in Ts. 18 and 19 S., R. 6 E., Salt Lake meridian. In the western part of the plateau the formation consists of the former lower Wasatch exclusive of the basal conglomerate, which is now placed in the Price River formation. The North Horn includes an assortment of the lithologic types hitherto considered regionally characteristic of the Tertiary-variegated shale and sandstone, conglomerate, freshwater limestone, and other beds-which at the type locality is clearly divisible into four gross units as shown in the following section.

Generalized section of North Horn formation at type locality on southwest point of North Horn Mountain

Flagstaff limestone (forms top of mountain).

North Horn formation:

1. Shale, red and variegated in upper part, gray in lower part, with interbedded buff and gray sandstone and some limestone, the bedding very even and individual layers thin; lacustrine in origin; forms steep slopes and cut banks beneath limestone cliffs or Flagstaff

2. Shale, gray to variegated, with thin beds of buff sandstone, in general irregularly bedded; floodplain deposits ; forms gentle slopes

3. Shale, gray to black; sandstone, buff to light cream and gray, chiefly fine; some limestone, in very evenly bedded succession, layers generally not over 5 feet thick; mainly lacustrine; generally capped by resistant sandstone and forming shoulder or terrace with steep front slope

4. Shale, gray in lower part, variegated in upper; sandstone, buff to gray, mainly medium to fine but with conglomerate in places; minor amounts of limestone; dominantly flood plain in origin; forms gentler slopes between unit 3 and Price River formation

Sandstone of Price River formation (exposed above Castlegate sandstone member on Rock Canyon Creek).

Total North Horn 1,650

The North Horn formation in this part of the plateau thus represents an alternation between fluviatile and lacustrine conditions. Units 1 and 3 bear the distinguishing characteristics of lake deposits; units 2 and 4 show dominantly the irregular bedding, nonpersistence of layers, and variety of physical constitution that are typical of flood-plain and channel deposits. As they appear at the type locality, these units may be recognized on plate 22 .

\section{REGIONAL CHARACTERISTICS}

In the central part of the plateau the four units distinguished in the section on North Horn Mountain are regularly present and easily traceable in an area of about 600 square miles, the center of which is east of Manti. In all directions away from this area the fourfold division gradually disappears, other large-scale divisions locally taking its place, but the whole formation becomes generally more unified. This regional unity is of significance in the matter of age relations, as is brought out in succeeding paragraphs. The formation thickens to the north and east, attaining 2,200 to 2,500 feet between Castlegate and Soldier Summit, and generally thins westward, a minimum of about 500 feet having been observed on Salina Creek. ${ }^{43}$ In the eastern part of the plateau it contains freshwater limestones and other lacustrine beds irregularly scattered throughout, and in places it is impossible to define a contact with the Flagstaff. A few thin beds of poor coal are also present here. In general, the North Horn strata constitute a record of rapidly shifting flood-plain and lacustrine conditions.

A few salient facts respecting the distribution of the formation east of the Wasatch Plateau are given on page 140.

\section{RELATIONS TO ADJACENT FORMATIONS}

The North Horn formation grades downward into the conglomerate or sandstone of the Price River formation, with no evidence of break, at all places where the two formations are known. It passes likewise transitionally upward into the Flagstaff limestone in most of central Utah. On the western margin of the plateau, however, all four units of the type section were tilted and truncated by erosion before the deposition of the Flagstaff, as shown in figure 17. The disturbance that produced this angular unconformity was apparently confined to a narrow zone now roughly coincident with Sanpete Valley, and the only place where the angular contact between the Flagstaff and the North Horn can be proved to be depositional is the Sixmile locality, not far south of Manti. Throughout the western piedmont of the plateau-west of the eastern margin of this disturbance-the Flagstaff overlies all older rocks in angular contact, but everywhere, except at Sixmile Canyon and two other localities, the contact is a thrust fault of the type-described by Billings ${ }^{44}$ as strip thrusts. The thrusting is much easier to explain, however, if it is assumed to have taken place along a preexisting angular unconformity. At two widely separated localities, one

${ }^{43}$ Spieker, E. M., and Baker, A. A., op. cit. (1925), p. 144 (lower unit of section given).

${ }^{44}$ Billings, M. P., Tharusting younger rocks over older : Am. Jour. Scl., 5th ser., vol. 25 , pp. 153-155, 1933.

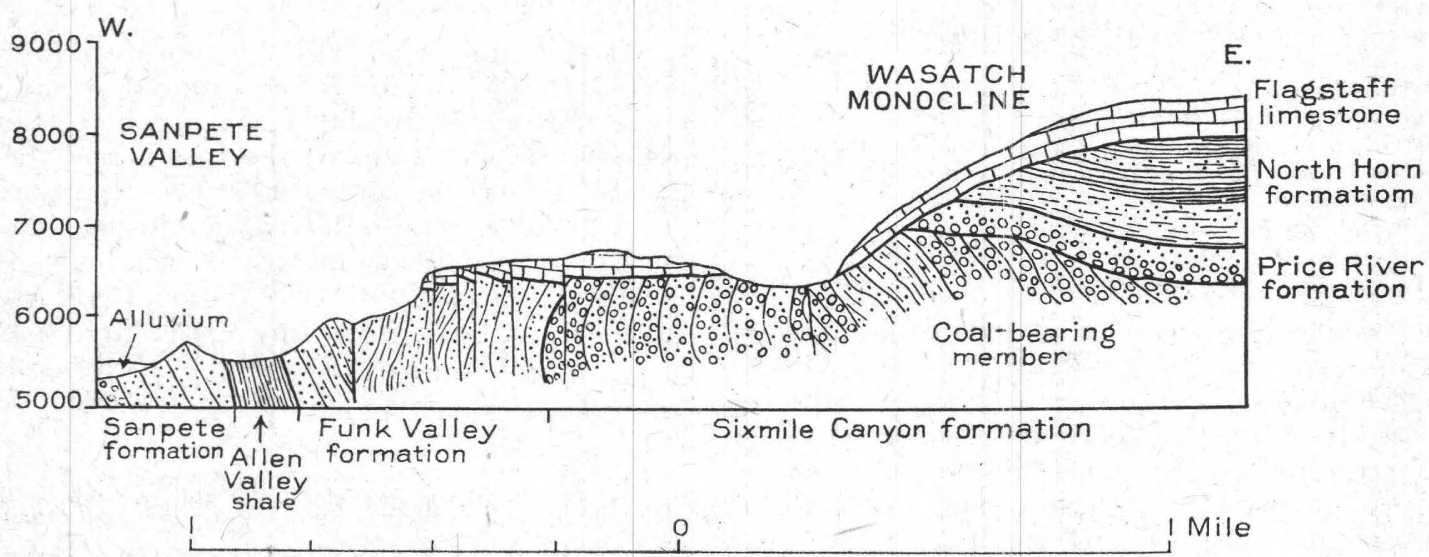

FIGURE 17.-Cross section of rocks exposed in Sixmile Canyon near Manti. 
in Salina Canyon 3 to 5 miles east of Salina (see pl. $25, B$ ) and the other 2 miles east of Indianola, the basal Flagstaff overlies steeply folded Jurassic and Cretaceous rocks in angular unconformity that has not been deformed by thrusting. The interpretation of this preFlagstaff unconformity is further considered in the discussion of the Flagstaff limestone. (See p. 136.)

Thus, despite the regional appearance of transition in the passage from North Horn to Flagstaff east of the Wasatch monocline, in the western districts the two formations were unmistakably separated by a physical disturbance. The significance of this disturbance in the regional history is discussed in the part of this paper devoted to orogenic movements. (See p. 155.)

Whether or not the apparent transition between North Horn and Flagstaff signifies actual continuity of deposition during the epoch of disturbance and erosion on the west, it is worthy of note that no effects of the folding are visible at remarkably short distances to the east of the disturbed belt. In Sixmile Canyon, for example (see fig. 17), the angular unconformity may clearly be seen to pass eastward into a disconformity, all trace of which disappears within a mile up the canyon. In other canyons to the south, where the angular unconformity passes underground eastward, the rocks rising on the monocline to the east show transition at the base of the Flagstaff, within a few miles. These facts are plain; but it is difficult in face of them to picture the disposal of the coarse sediments that must have resulted from the erosion of the upturned Cretaceous sandstones and conglomerates. As matters stand, the evidence must be accepted as showing that a pronounced disturbance may produce no directly observable effect in contemporaneous strata very near to the folded area.

\section{AGE AND CORRELATION}

Evidence bearing on the age of the North Horn formation rests in two groups of fossils, one of freshwater mollusks and the other of vertebrates. The invertebrates so far collected are brought together in the following list.

Fossils from North Horn formation, about 1,000 feet above base, on Wasatch Plateau east of Mount Pleasant, Utah

[Identified by J. B. Reeside, Jr.]

Unio letsoni Whitfield.

Unio n. sp. aff. U. letsoni and U. biesopoides Whitfield. Unio priscus Meek and Hayden.

Unio cf. U. clinopisthus White.

Unio cf. $U$. shoshonensis White.

Bulinus cf. B. subelongatus Meek and Hayden.

Bulinus cf. B. atavus White.

Bulinus longiusculus Meek and Hayden.

Columna? teres Meek and Hayden.

Goniobasis aff. G. tenuicarinatus Meek and Hayden.

Goniobasis tenuicarinatus Meek and Hayden.

Viviparus trochiformis Meek and Hayden.

Viviparus panguitchensis White.

Viviparus nanus White.

Viviparus cf. V. wyomingensis Meek.

These are the fossils, mentioned on earlier pages, that first aroused suspicion as to the Wasatch strata of central Utah. Their significance was at first set aside as uncertain, largely because of the general reputation for long range sustained by freshwater faunas. The results of the present investigation, however, suggest that the values involved may be underestimated, and the writer feels that the freshwater mollusks of the stages here discussed deserve thoroughgoing, restrictive study on a precise stratigraphic basis. This opinion, several years in the making, was definitely fixed when Reeside ${ }^{45}$ brought to attention the fact that many species are on record as Wasatch because they were described in the pioneer days from strata then identified as Wasatch but now either uncertain in stratigraphic position or known not to be Wasatch. An outstanding example is the record of Wasatch species by C. A. White from Wales, Utah; ${ }^{46}$ the beds there from which White collected are now known to belong to the Price River, North Horn, and Flagstaff formations. In the wide territory over which the Wasatch formation has been mapped, comparatively few localities have yielded the diagnostic vertebrate faunas; all others should be held in doubt.

Vertebrate remains have been found in two general zones of the North Horn formation, one in unit 4 of the section earlier given, from 140 to about 500 feet above the base, and an upper zone in unit 2. From the lower zone, collections were made in 1935 by J. B. Reeside, Jr., and the writer at 26 stations, of which 23 are on the southwest ridge of North Horn Mountain, in the type area of the formation, and the remaining three in Manti, Sixmile, and Twelvemile canyons on the west slope. The material has been identified by C. W. Gilmore as dinosaurian, chelonian, and crocodilian as follows (summarized from all localities):

\section{Cèratopsia:}

Frill fragments, horn cores, dentary bones, vertebral centra, tooth, metapodial, terminal phalanx, caudal centrum, squamosal, parietal, skull, and other bone fragments.

Theropoda :

Caudal vertebra, teeth.

Hadrosauridae :

Radius, ulna, metacarpals, phalangials of hind foot. Smaller than any other known Hadrosaurian.

Chelonia :

Plates of Trionychid, and genera Basilemys, Baena. Crocodilia :

Tooth, vertebral centrum.

Nearly all these fossils represent groups distinctive of the Upper Cretaceous. Most informative are the Ceratopsia, concerning which Gilmore says:

The Ceratopsians, judged from this collection, were the predominating animals of this area, as their remains are recognizable from 11 different collecting stations. One specimen, consisting of the right squamosal and so-called parietal, shows a frill development unlike any described form but sufficiently perfect to indicate its distinctness from those having fenestrated frills; and since the nonfenestrated forms are all confined to the Lance formation or its equivalents, the inference is that the present specimen comes from a formation that is close to, if not equivalent to it in age.

At the time when this vertebrate material was collected the question was considered whether the bones were indigenous to the strata in which they occur; the fragmental character of the fossils and their generally sparse occurrence suggested at first that they might have been derived from older rocks, but the sum of evidence was interpreted ${ }^{47}$ to mean that the bones were in their original place of burial. Material collected by C. W. Gilmore in 1937, including articulated parts of skeletons, notably one of a giant sauropod, removes all doubt on this question.

${ }^{45}$ Reeside, J. B., Jr., personal communication.

${ }^{4}$ White, C. A., On the relation of the Laramie molluscan fauna to Geol. Survey Bull. 34, 1886 .

Geol. Survey Bull. 34, 1886 . vol. 83,1936 . 
The dinosaurian remains come from the lower 500 feet of the formation. The middle part has yielded no vertebrate fossils diagnostic of age, but the upper part contains mammalian bones unquestionably Paleocene in age. In 1935 a poorly preserved fragment of a small skull was found, which was characterized by C. L. Gazin and G. G. Simpson as generically unidentifiable but in their opinion not Cretaceous in age, and on the basis of this statement the writer made a tentative announcement ${ }^{48}$ that the passage from Cretaceous to Tertiary lies within the North Horn formation. Collections made in 1937 by C. W. Gilmore and studied by Gazin ${ }^{49}$ confirm this conclusion.

The North Horn formation thus embodies strata of latest Cretaceous and earliest Tertiary ages, probably to be correlated in some part with the Lance and Fort Union formations of the northern plains, and with the Ojo Alamo, Puerco, and Torrejon formations of the San Juan Basin, to mention the two regions that have afforded most complete fossil evidence in this part of the geologic column. It is of especial interest and significance that the passage from Cretaceous to Paleocene is recorded by an apparently transitional succession of strata. As pointed out in the foregoing description of the formation, no physical basis for regional subdivision of the strata grouped in the North Horn formation has been recognized, and in the present state of knowledge a boundary between Cretaceous and Paleocene cannot be mapped. The transition is apparently even more complete than in the areas of Montana and Wyoming, where distinction between Lance and Fort Union has been the subject of much discussion. This phenomenon is of major importance in the CretaceousTertiary boundary question, which is discussed at some length farther on in this report. (See pp. 142-146.)

\section{USE OF TERM PALEOCENE}

The term Paleocene, introduced on paleobotanical grounds by Schimper ${ }^{50}$ in 1874 , has been widely used in Europe to designate the lowermost division of the Tertiary, an epoch of standing equal to that of the Eocene, Oligocene, Miocene, and Pliocene. In North America this division was not generally recognized until the vertebrate paleontologists began to recognize notable differences between the mammalian faunas of the lowermost Tertiary (Fort Union, Puerco, Torrejon, and Tiffany) and those of the overlying Eocene (Wasatch). These differences seemed to warrant the separation of the basal strata from the remainder of the Eocene, and among the vertebrate paleontologists acceptance of the Paleocene as a standard division of the Tertiary has come to be universal. ${ }^{51}$ Other American geologists, however, have been slower to adopt the term, but have generally preferred to include the strata concerned in the Eocene, commonly using for them the designation basal Eocene, in distinction from the lower Eocene, to which the Wasatch strata have Jong been assigned. The United States Geological Survey followed this procedure until June 12, 1939, when the name Paleocene was officially approved.

The Paleocene, as thus recognized by the Geological Survey, comprises the time during which the Fort Union and equivalent strata of the Cordilleran Interior were deposited. It is a series and epoch term, on parity with Eocene and the other recognized divisions of the Tertiary.
The Paleocene of most European geologists, however, follows the original definition of Schimper, which includes more than the interval specified above. The Fort Union formation of the northern plains and beds containing the Puerco, Torrejon, and Tiffany faunas of the San Juan Basin are equivalent to the strata of the Montian and Thanetian stages of the standard European column. The European Paleocene includes, in addition to these two stages, the Sparnacian, which is the equivalent of the North American Wasatch. Without entering upon a discussion of the basis on which the European partition rests, it may simply be observed that for North America the most effective division separates the Fort Union and the Wasatch. Not only are the faunas of these two units distinct, but the Wasatch fauna marks the beginning of a unified succession that continues upward through the Eocene. If the Paleocene is to be recognized by American geologists, its upper limit must be set at the top of the Fort Union. As to reconciliation with the European scale, it is obviously unfortunate that complete agreement cannot be attained, but the advantages to North American geologists of the classification here given outweigh the disadvantages involved in making allowances for differences in international usage. Further, when it is recognized that the North American section, comprising in its best development thousands of feet of strata and a rich succession of mammalian faunas, is probably the fullest record of early Tertiary time in the world, the possibility may be considered that a reasonable standard Paleocene for the whole world might follow these lines. In other words, the reasons given in North America for excluding the Sparnacian equivalents from the Paleocene might outweigh those given in Europe for including the Sparnacian.

\section{TERTIARY SYSTEM}

FLAGSTAFF LIMESTONE

\section{DEFINITION, LITHOGRAPHIC CHARACTER, AND EXTENT}

The name Flagstaff limestone is here applied to the strata hitherto described as the Flagstaff limestone member of the Wasatch formation, ${ }^{52}$ and no redefinition of stratigraphic limits is necessary. As long as the Flagstaff was considered to be a lacustrine phase between flood-plain deposits of Wasatch age, its inclusion in the Wasatch formation was consistent. Now, however, the former lower member is known not to be of Wasatch age, and the Flagstaff is known to be more closely related to the Green River formation than to the strata formerly classified as Wasatch. As pointed out below, it contains fossils that suggest an age older than Wasatch. In thickness and extent it is one of the major stratigraphic units of the region, and in view of these facts it is elevated to formational rank.

The Flagstaff limestone is present throughout the Wasatch Plateau and extends in all directions for unknown distances, except eastward, where, although it has been eroded from the vast basin of the Colorado

\footnotetext{
48 Spieker, E. M., Late Cretaceous-early Eocene history of central Utah; Geol. Soc. America Proc. 1935, p. 374 (abstract), 1936. ${ }^{49}$ Gazin, C. L., A Paleocene mammalian fauna from central Utah : 50 ${ }^{50}$ For a definitive statement see Wilmarth, M. G., The geologic time other classifications: U. S. Geol. Survey Bull. 769, pp. 54-56, 1925. other classifications : U. S. Geol. Survey Bull. 769 , pp. $54-56,1925$. and its mammalian fauna; U. S. Nat. Mus. Bull. 169, pp. 16, 21, 1937. Scott, W. B., A history of land mammals in the western hemisphere, $2 d$ ed., pp. 99-100, 230-232, Macmillan, 1937.

52 Spieker, E. M., and Reeside, J. B., Jr., op. cit. (1925), pp. 448-449. Spieker, E. M., op. cit. (Bull. 819), p. 46 .
} 
River, its extent in the plateaus north of the Book Cliffs is roughly known. It consists dominantly of freshwater limestone of many kinds, with interbedded gray shale and minor amounts of sandstone, gypsum, oil shale, and volcanic ash. Toward the west it contains coal, locally, and southwestward much of the limestone is silicified. It lacks generally the red and variegated beds that characterize the adjacent formations and is easily distinguished in general view by its extensive white or cream-colored outcrops, which form a striking and almost unique scenic feature of the higher tabular masses in the Wasatch Plateau. (See pl. 22.) Its lithologic character is too varied for more than summary mention in this paper.

In the Wasatch Plateau the Flagstaff limestone ranges between 200 and 1,500 feet in thickness, with an average between 800 and 1,000 feet; it is generally thicker westward and southwestward. In the southern part of the plateau proper, where it is more than 1,000 feet thick and almost exclusively fresh-water limestone, it is an imposing body of rock, forming high cliffs and parapets on the crest of the plateau, which dominate the landscape and are visible from the bordering valleys for many miles.

\section{REGIONAL RELATIONS}

Between Soldier Summit and Thistle the red beds and sandstones formerly designated the upper member of the Wasatch formation (the Colton formation of this report) change westward, by gradation and intertonguing, to white and gray shale, sandstone, and limestone of the Green River, so that in the Thistle district there are no strata of the variegated type immediately overlying the Flagstaff. Here the Green River type of lithology really begins at the base of the Flagstaff. Similar relations are observable south of the line of this section; for example, in the Gunnison Plateau and in parts of the western border belt of the Wasatch Plateau, the Colton strata are absent or are seen to change laterally into Green River beds. In general, the Flagstaff has the actual form of a tongue of Green River strata extending southward and eastward from the Thistle district for radial distances well over 75 miles.

Despite this clear-cut relationship, the Flagstaff is not formally designated a tongue of the Green River formation. Its thickness and extent bespeak formational rather than subsidiary rank; although in general of the Green River type, it differs sufficiently in dominance of limestone to be separated; and it is older, perhaps considerably older, than the typical Green River. The facts that bear on its position in regional nomenclature suggest separation from the Green River as an individual unit.

However, apart from the interests of nomenclature, the fact remains that the Flagstaff of the western districts represents the initiation of widespread lacustrine conditions that apparently continued uninterrupted through the deposition of the Green River formation, the dominant type of sediment changing upward from limestone to shale. This is of interest in that it shows an extension, in area as well as in time, of the Uinta Lake of Bradley, ${ }^{53}$ in which these sediments were deposited.

The Flagstaff limestone has been traced to the southern limits of the Wasatch Plateau, roughly 100 miles from the western end of the Uinta Basin. The thickest known sections are in the southern part of the Wasatch
Plateau. Its extent farther south is not exactly known; it appears to be absent in the high plateaus immediately south of the Wasatch Plateau, but it may have been removed by erosion. In the extreme southern districts of the High Plateaus the beds assigned to the Wasatch formation contain thick units of limestone whose similarity to the Flagstaff, in stratigraphic position as well as in lithology, is evident from available descriptions ${ }^{54}$ and has been verified in part by the writer's observations. If these southern beds are Flagstaff, the northsouth extent of the formation is at least doubled, and the area of Uinta Lake is accordingly increased. In the writer's opinion the southern limestones are more likely Flagstaff than not.

\section{AGE AND CORRELATION}

Some of the limestone beds in the Flagstaff are charged with fresh-water gastropods and pelecypods. It is important to note that the Flagstaff of the Wasatch Plateau contains certain of the very species that at first caused doubt as to the Wasatch age of the North Horn strata (for example, Unio priscus, Viviparus panguitchensis, $V$. leai), and that some of the fossils described by C. A. White from Wales, Utah (see p. 134), may have come from the Flagstaff. Despite the uncertainty of this evidence, the writer is inclined toward the same interpretation as that which eventually was demonstrated to be valid for the North Horn invertebrates, namely, to consider the Flagstaff limestone as probably Paleocene in age. The relations between the Flagstaff and the upper part of the North Horn, which probably belongs in the middle part of the Paleocene and not the upper, tend to favor this hypothesis; the Flagstaff probably followed the North Horn with no great lapse of time, and might easily have been deposited in the later part of the Paleocene. As matters stand, the age of the Flagstaff, frankly to be regarded as uncertain, seems more likely to be Paleocene than lower Eocene.

\section{PRE-FLAGSTAFF UNCONFORMITY}

The regionally dominant transition between the Flagstaff limestone and the underlying North Horn formation, and the angular break between the two in Sixmile Canyon, are described in the foregoing section on the North Horn formation. There should be added here, however, some discussion of the angular unconformity in the western districts where the Flagstaff overlies all the older rocks of the region. This unconformity is interpreted in the present study as the result of the same movement as that which produced the angular relations between the Flagstaff and the North Horn in Sixmile Canyon. Inasmuch as Sixmile Canyon is the only locality at which the North Horn strata have been found beneath the unconformity, and further in view of the difficulty there of ascertaining the true relations, question may arise respecting the extent of the orogenic movement postulated, if not as to its actual validity.

The pre-Flagstaff unconformity is widely present in the western border belt of the Wasatch Plateau and adjacent valleys between Salina and Manti. It is also present in a hogback not far east of Indianola, where the Flagstaff overlies vertical Arapien shale only a few miles from abundant exposures in which the full normal sec-

${ }^{53}$ Bradley, W. H., Varves and climate of the Green River epoch : U. S. Geol. Survey Prof. Paper 158, p. 88, 1930. Geol. Survey Prof. Paper 164, pp. 114-116, 1931. 
tion is present. The possibility to be considered is that these unconformable contacts resulted, not from erosion and burial of rocks folded in the post-North Horn disturbance, but from the presence of areas that remained high after the early Laramide folding and that were first submerged by the Flagstaff lake. Such areas are known along the east front of the Wesatch Mountains; Eardley, ${ }^{55}$ Schoff, ${ }^{56}$ and Baker ${ }^{57}$ have observed that the entire post-early Laramide succession overlaps the steep front of the ancient mountains, with the Flagstaff resting in places on folded Paleozoic and Mesozoic rocks. At these localities the rocks that appear toward the east between the Flagstaff and the folded mass, generally North Horn strata, show no evidence of pre-Flagstaff disturbance. ${ }^{58}$ Relations similar to these, in the same general belt, are described elsewhere in this paper. (see pl. 24, A.)

It is possible that the unconformity in the SalinaManti and Indianola districts is of the same sort. The writer prefers, however, the interpretation that it resulted from post-North Horn erosion, for the following reasons. First, the pre-Flagstaff erosion surface is very extensive in the Manti-Salina district, and it is remarkably even (see pl. $25, B$ ) ; in these respects it is quite different from the occurrences on the old mountain front cited above. Second, it is many miles from the old mountain front-at least 25 miles in the latitude of Sixmile Canyon-assuming the front to have been at the site of the present Canyon Range. That so extensive a surface should have remained positive so far from the mountains and for so long a time-from late middle Montana to middle Paleocene, approximately-while areas much nearer to the mountains were receiving notable thicknesses of Price River and North Horn sediments, seems less probable than the alternative here suggested. Third, conglomerate of the Price River formation was deposited on the older erosion surface in the Sixmile district, and there this surface is definitely truncated by the later one, as shown on figure 17. In weighing the fact that this locality is the only one that shows angular relations between the North Horn and the Flagstaff it must be recognized that in the folded belt the only other canyon that cuts through the angular unconformity is Salina Canyon. In that canyon the unconformity passes beneath creek level before the critical part of the section appears; the highest folded rocks beneath it are sandstones of the Funk Valley formation. In other words, the North Horn-Flagstaff contact is buried in the part of the canyon where it might show an angular break.

Another line of evidence that suggests extensive rather than localized activity in the pre-Flagstaff disturbance is purely structural in nature. When the fold produced in the latitude of Sixmile Canyon is restored to its original condition, it turns out to have been a monocline of the type classic in the Colorado Plateaus to the southeast. The nature of the structure and its place in the regional scheme are discussed farther on, in the summary of orogenic history. Structures of this order are generally extensive along the strike, not localized. A minor upwarp restricted to the vicinity of Sixmile Canyon is of course possible, but the sum of evidence seems to favor a larger structure.

These considerations lead the writer to think that the disturbance between North Horn and Flagstaff time penetrated a considerable part of the border area of the Wasatch Plateau.

\section{WASATCH PROBLEM}

The general problem of identifying the Wasatch formation in central and eastern Utah is outlined in the first part of this paper, and the changes in nomenclature now required for part of the former Wasatch are set forth in the foregoing discussions of the North Horn and Flagstaff formations. Now that the former lower member of the Wasatch is known not to be Wasatch in age, and serious doubt is cast on the Wasatch age of the Flagstaff, the question arises, how much of the remaining section may still properly be assigned to the Wasatch formation? The attempt to deal with this question leads at once into a larger problem, involving the stratigraphic significance of the name Wasatch in the entire Cordilleran region. From Montana to New Mexico the name has been applied, on the basis of various criteria, to strata presumably of lower Eocene age. Modern investigations by both stratigraphers and paleontologists are raising questions on all important aspects of this usage, and the many problems entailed are by no means easy to resolve. The full range of this subject is beyond the scope of the present report; however, much of the stratigraphic revision involved in the conclusions here presented has resulted in some way from a study initially concentrated on the Wasatch problem, and it seems worth while to summarize the major elements of the question, if only to explain the nomenclature adopted in this report.

The name Wasatch, one of the oldest survivors among terms used by pioneers in western American stratigraphy, was proposed in 1869 by Hayden ${ }^{59}$ to include the strata exposed along the Union Pacific Railroad between Carter Station, Wyo., and Echo Canyon, Utah. This obviously generalized definition covered a fairly wide stratigraphic range, yet it served as basis for Veatch ${ }^{60}$ to outline more precisely the strata that he included in his Wasatch group, separated into the Almy, Fowkes, and Knight formations, in ascending order. Not long after Hayden's work Cope ${ }^{61}$ described from the type area the fire representatives of the lower Eocene vertebrate fauna that later became famous as the Wasatch fauna and served as basis for the establishment of a time stage in the early Tertiary. Areal geologists, following Hayden and Veatch, mapped the Wasatch formation on lithologic and stratigraphic criteria over extensive areas. Vertebrate paleontologists found other occurrences of the so-called Wasatch fauna, and it became widely known. The name Wasatch gained prominence in usage and was included in standard sections of the North American Tertiary published all over the world.

This usage, however, has been far from uniform. That of the areal geologist has only slightly coincided with that of the vertebrate paleontologist; the diagnostic mammalian fauna has been found in only a few of the many areas where the Wasatch formation has been mapped. The usage of the paleontologist has adhered for the most part to a time stage approximately equivalent to the Sparnacian of the European scale, and with

\footnotetext{
${ }^{55}$ Eardley, A. J., A limestone chiefly of algal origin in the Wasatch conglomerate, southern Wasatch Mountains: Mich. Acad. Sci. Papers,
vol. 16, pp. 399-414, 1932.
56 Schoff, S. L., Geology of the Cedar Hills, Utah (unpublished notes).

57 Baker, A. A., Geology of the Cedar Hills, Utah (un

58 See especially Eardley, A. J., op. cit., fig. 12, p. 401.

59 Hayden, F. V., U. S. Geol. Survey Terr., 3d Ann. Rept., p. 90, 1869; idem, 2d ed., p. 191, 1873

${ }_{60}$ Veatch, A. C., Geography and geology of a portion of southwestern Wyoming: U. S. Geol. Survey Prof. Paper 56, pp. 88-96, 1907.

${ }_{61}$ Cope, E. D., On the vertebrate fossils of the Wasatch strata ; U. S. Geol. Geog. Survey Terr., 5th Ann. Rept., pp. 350-353, 1872.
} 
the progress of detailed study it has been refined by subdivision in which reference to the original Wasatch is not entirely satisfactory. Although the areal geologists have generally had in mind the lower Eocene time stage when they have identified the Wasatch formation, yet in places such as the area covered by this report and in western Colorado ${ }^{62}$, strata mapped as Wasatch have been found to belong in older time divisions. One factor, which has contributed to the uncertainty of identification, is the stratigraphic confusion of freshwater mollusks already discussed in this paper. Although vertebrate remains have not been extensively found, invertebrate fossils have been widely collected and have been used to support the physicial identification of the Wasatch strata.

An outstanding aspect of the regional stratigraphy that has played a part in the areal identification of the Wasatch strata is the common occurrence in the part of the section assigned to the lower Eocene of variegated beds with varying amounts of coarse-grained sandstone and conglomerate (Wasatch) overlain by evenly bedded shale, limestone, and fine-grained sandstone (Green River). These two lithologic types intertongue, and the units are therefore partly equivalent in age from place to place. The fairly uniform appearance of this characteristic sequence in the highlands and structural basins of the Cordilleran region and the recognition of it as part of the standard Eocene sequence (Wasatch, Green River, Bridger, Uinta) have encouraged geologists to identify the variegated beds beneath the Green River as Wasatch. Further, and more important as regards the problem of nomenclature here considered, it gave rise to the essential concept of Wasatch as composed of fluviatile sediments laid down on flood plains bordering and finally submerged by the lakes in which the contrastive Green River sediments were deposited.

Out of these considerations arise several questions. What does the name Wasatch mean? Should it be retained, and if retained, how should it be applied? Should it be restricted to (1) strata homogenetically equivalent to those of the type section; (2) strata of flood-plain environment as opposed to lacustrine, with or without regard to precise age relations; (3) strata definitely assignable to the time stage presumably established by the vertebrate faunas; or (4) conceivably, to categories involving other combinations of these elements?

In the stratigraphic sense usage should be established with reference to the type section, following the generally accepted rules of nomenclature. ${ }^{63}$ The type section, however, probably covers a stratigraphic range too extensive for practical purposes. Further, as subdivided by Veatch, ${ }^{64}$ the Wasatch group includes a strong angular unconformity between the Knight and older formations. Mansfield and Roundy concluded ${ }^{65}$ that this break might not exist, and after careful review of the evidence in the field the writer recognizes that there was ample reason for doubt, but it seems likely that the Almy formation, at least, underlies the Knight in angular unconformity. Traced regionally across southwestern Wyoming into northeastern Utah, the Knight formation is seen to overlap all the older folded rocks. Further, the section in Echo Canyon, part of the extensive original type area, embodies two angular unconformities - a lower one in the conglomerate series above Pulpit Rock, in addition to the break beneath the Knight, which is the one noted by Lee. ${ }^{66}$
The lower conglomerates, which have been generally classified as Wasatch, were placed in the Almy formation by Veatch. ${ }^{67}$ The stratigraphic identity of the Almy formation and its age constitute a problem that cannot be reviewed here, but it is the writer's opinion that the strata involved, especially the conglomerates of Pulpit Rock, belong in stages elsewhere established as older than Wasatch. If the term Wasatch were to be used in strict adherence to the type section, it would probably have to be applied to units for which usage has long since established names not only different, but also in part indicative of greater age than that customarily associated with the name Wasatch. In any event, until the actual content of the type section is carefully worked out, regional use of the term Wasatch in a strictly typical sense will be impossible.

Added to these uncertainties in physical stratigraphy is the fact that the vertebrate paleontologists, whose usage has been more nearly standard than any other, have become dissatisfied with the term Wasatch, ${ }^{68}$ and some of them favor abandoning it. ${ }^{69}$ The name has been applied to faunas both older and younger than that of the Knight formation in the type area and has lost whatever typical sense it may once have had; it has become essentially a generalized term covering the whole lower Eocene. It is impossible to say how far the generalized sense developed by the paleontologists agrees with the sense that would prevail if the original stratigraphic definition were strictly followed. No vertebrate remains have been found in the Almy and Fowkes formations, and no fossils of any sort sufficiently diagnostic for definite age determination. Neither is it possible to surmise the extent to which agreement would obtain under the provisions of any restrictive revision such as those mentioned in query above.

A logical conclusion from all this confusion and uncertainty would be to abandon the name Wasatch in favor of local terms more precise in significance. This is the conclusion reached by Nace ${ }^{70}$ in a regional review of existing usage. There is some merit, however, in the attempt to retain the name. In view of its long history and its familiarity to geologists everywhere, it might still serve to designate fluviatile sediments of the age indicated by the vertebrate fossils of the type area; in fact, if it were desired to formulate a restrictive definition in terms of the type area, logical grounds exist for applying the name to the strata included by Veatch in the Knight formation. For many miles around Wasatch Station, Utah, from which Hayden originally took the name, the strata exposed are typical Knight. Of course, Hayden made it clear ${ }^{71}$ that he intended to include in his Wasatch group "all the variegated beds which we have observed west of Carters station," and he specifically mentioned the mas-

${ }_{62}$ Patterson, Bryan, A contribution to the osteology of Titanoides and the relationships of the Amblypoda: Am. Philos. Soc. Proc., vol. 73, pp. $71-100,1934$.

port]

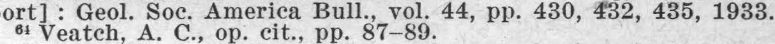

${ }^{65}$ Mansfield, G. R., Geography, geology, and mineral resources of part of southeastern Idaho: U. S. Geol. Survey Prof. Paper 152, p. 109, 1927. ${ }^{60}$ Lee, W. T., and others, Guidebook of the western United States,
pt. B, The Overland Route: U. S. Geol. Survey Bull. 612, p. 85, 1915. B
6 Veatch. A. C., op. cit., p. 89.

${ }^{68}$ Scott, W. B., A history of land mammals in the western hemisphere, 2 d ed., p. $100,1913$.

S9 Scott, W. B., Jepsen, G. L., Gazin, C. L., personal communications. Tace, R. L., Summary of the late Cretaceous and early Tertiary tratigraphy of Wyoming: Wyoming Geol. Survey Bull. 26, 1936. ${ }^{71}$ Hayden, F. V., Sun pictures of Rocky Mountain scenery, with a
description of the geographical and geological features and some account of the resources of the Great West, pp. 106, 107, 111, 113-114, New York, of the res
1870 . 


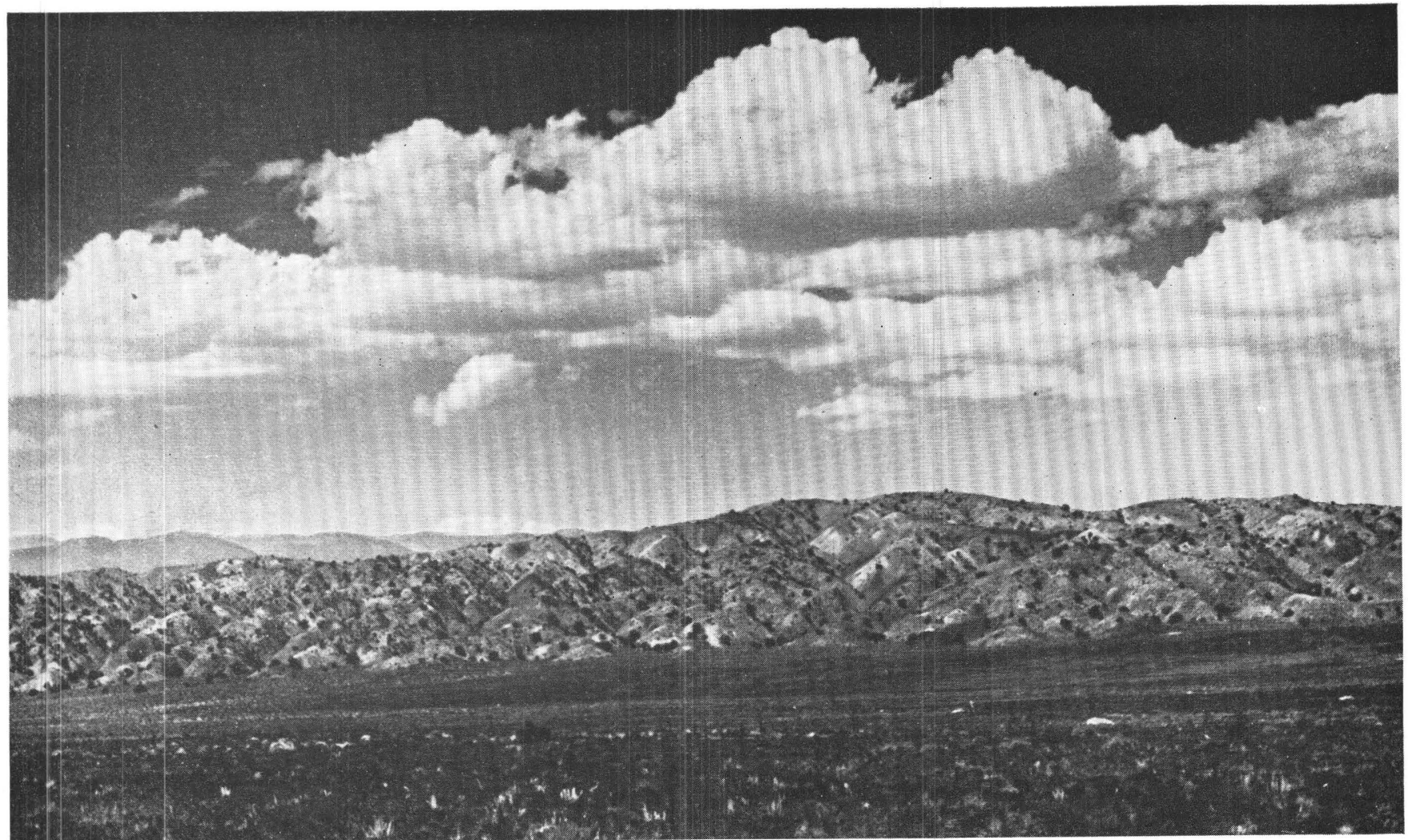

A. ARAPIEN SHALE AT THE TYPE LOCALITY IN ARAPIEN VALLEY.

View west across Arapien Valley south of Mayfield, showing characteristic blotched shale of Twelvemile Canyon member.

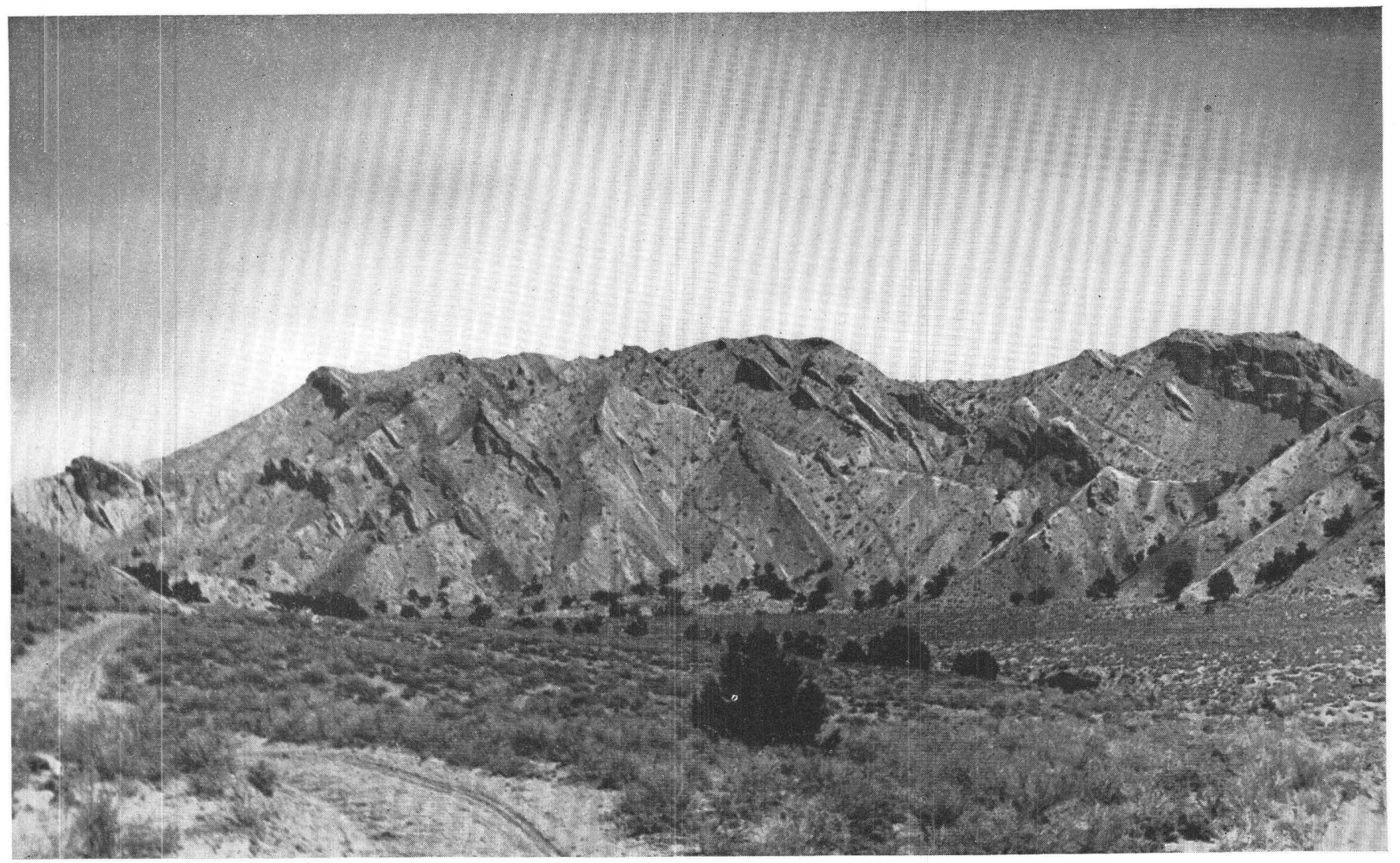

B. ARAPIEN SHALE IN THE SALINA DISTRICT.

Gypsiferous shale of Twelvemile Canyon member about 5 miles northeast of Salina. 


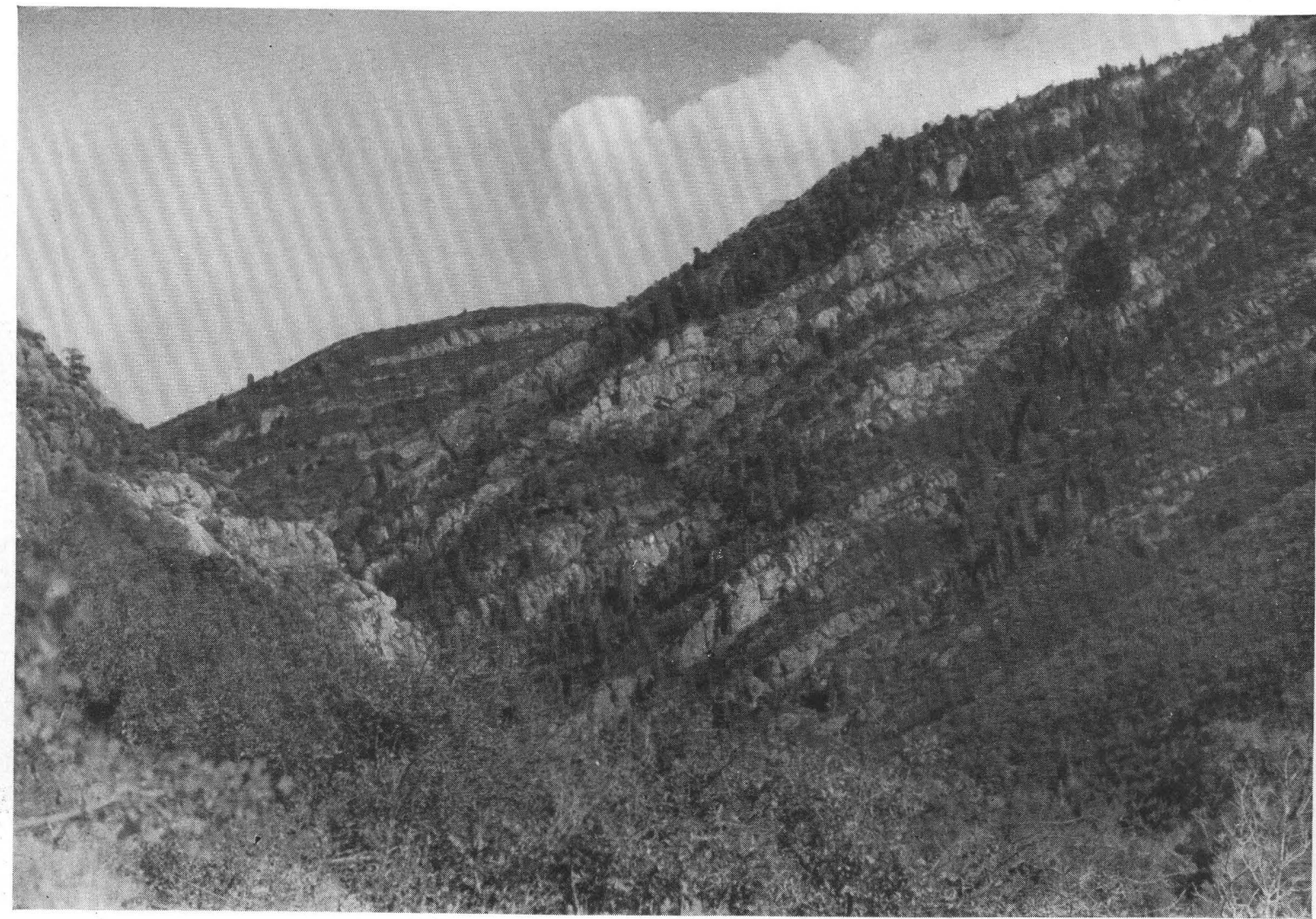

A. UNDIFFERENTIATED INDIANOLA IN THE GUNNISON PLATEAU.

View southeast across Chicken Creek Canyon, southeast of Levan. Ledges of massive conglomerate are the dominant rock.

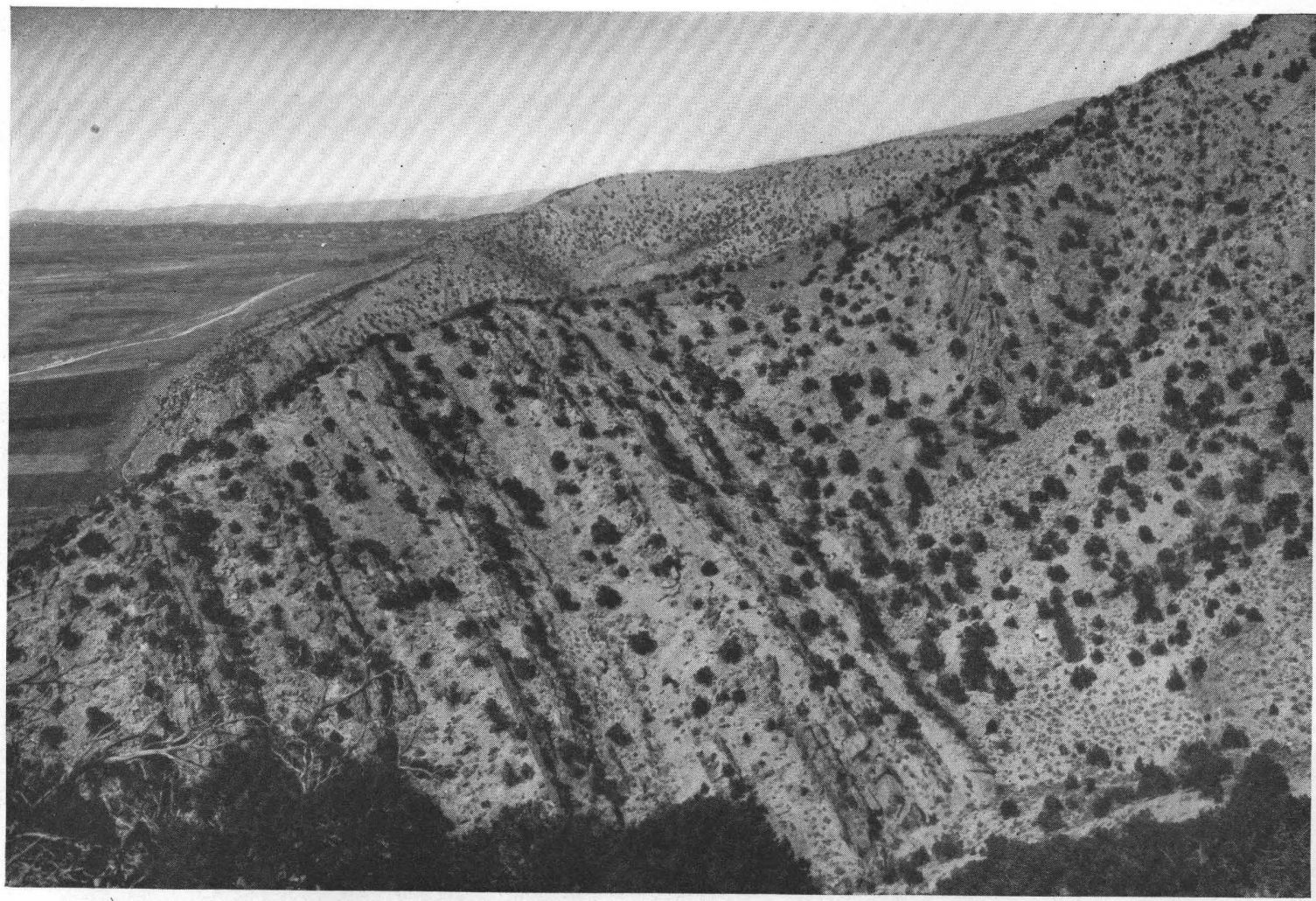

B. FUNK VALLEy FORMATION.

Steeply tilted sandstone and shale in the lower part of the formation on foothill ridge north of Funk Valley. Faulted capping of nearly horizontal Flagstaff strata faintly visible in middle distance; Sanpete Valley and town of Manti at upper left. 


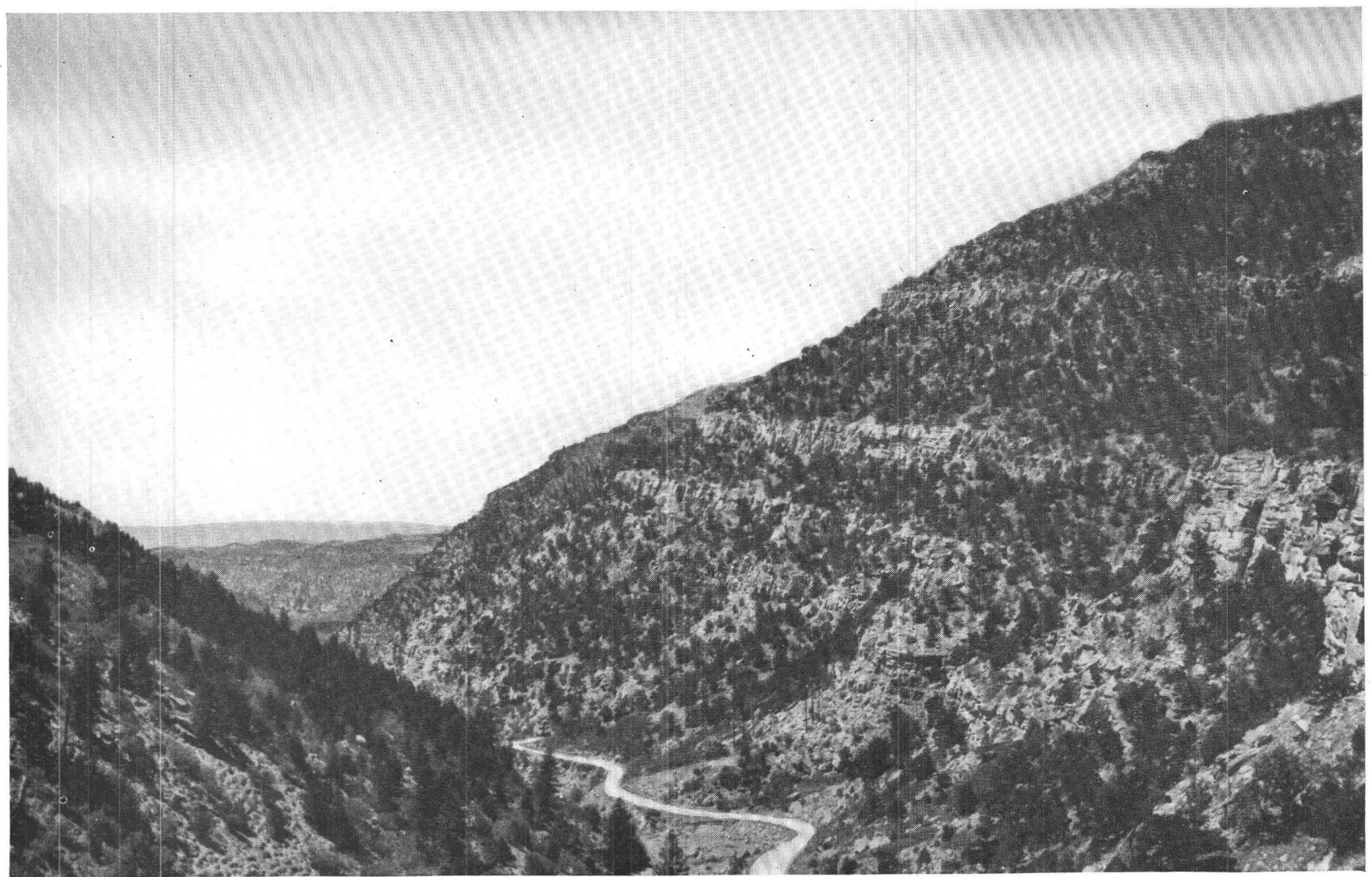

A. SANDSTONES ABOVE THE CASTLEGATE SANDSTONE MEMBER OF THE PRICE RIVER FORMATION IN WILLOW CREEK CANYON. The top of the Castlegate, at the locality shown in plate 20, $B$, is just visible to the right of the noteh. The Wasateh Plateau is seen in the distance.

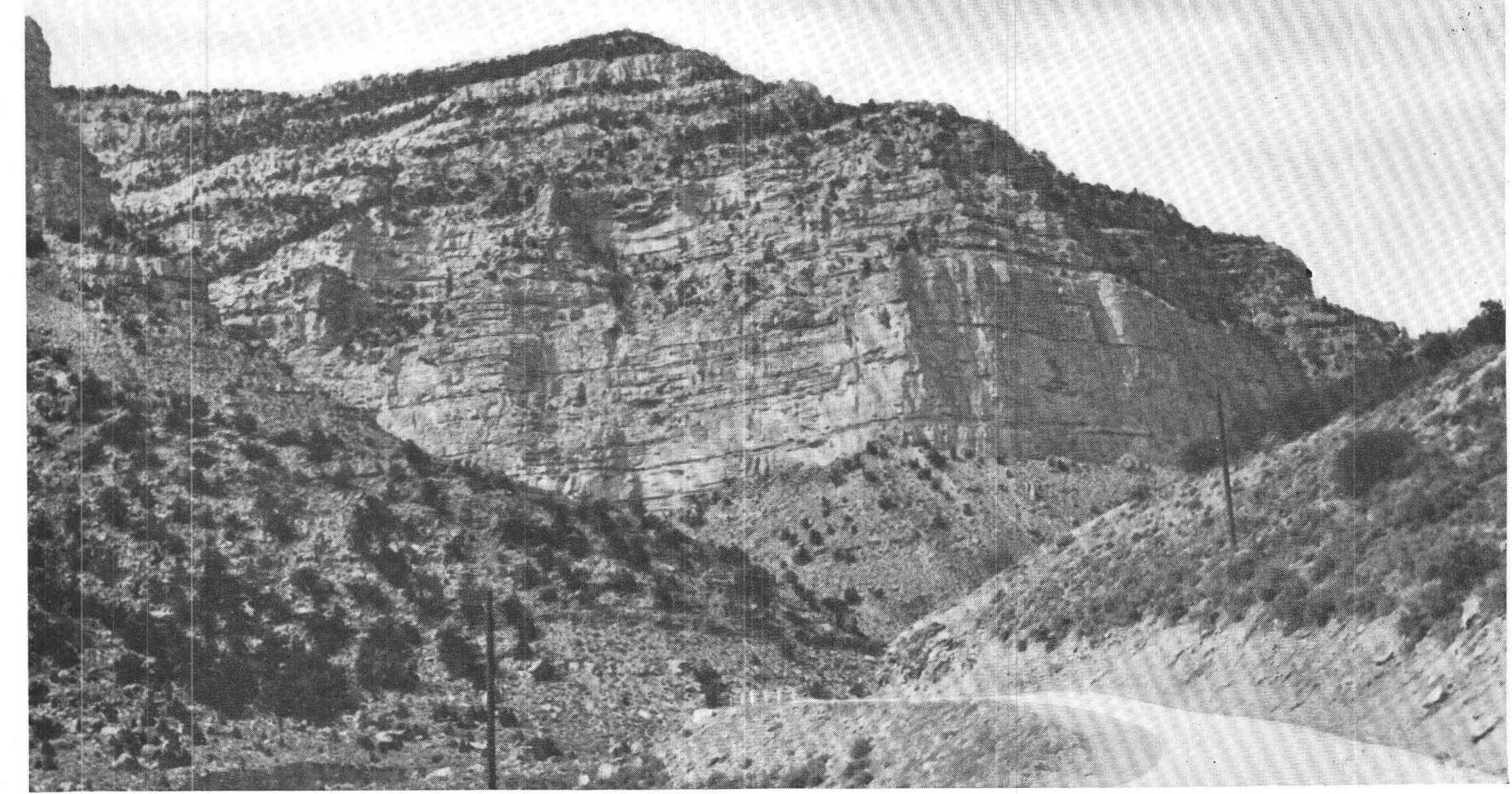

B. CASTLEgate SANDSTONE MEMbER OF THE PRICE RIVER FORMATION ABOUT A MILE ABOVE CASTLEgate. A characteristic exposure of the Castlegate near the type locality. The entire unit, about 500 feet thick, makes the massive cliff. Above is the upper sandstone member of the Price River. 


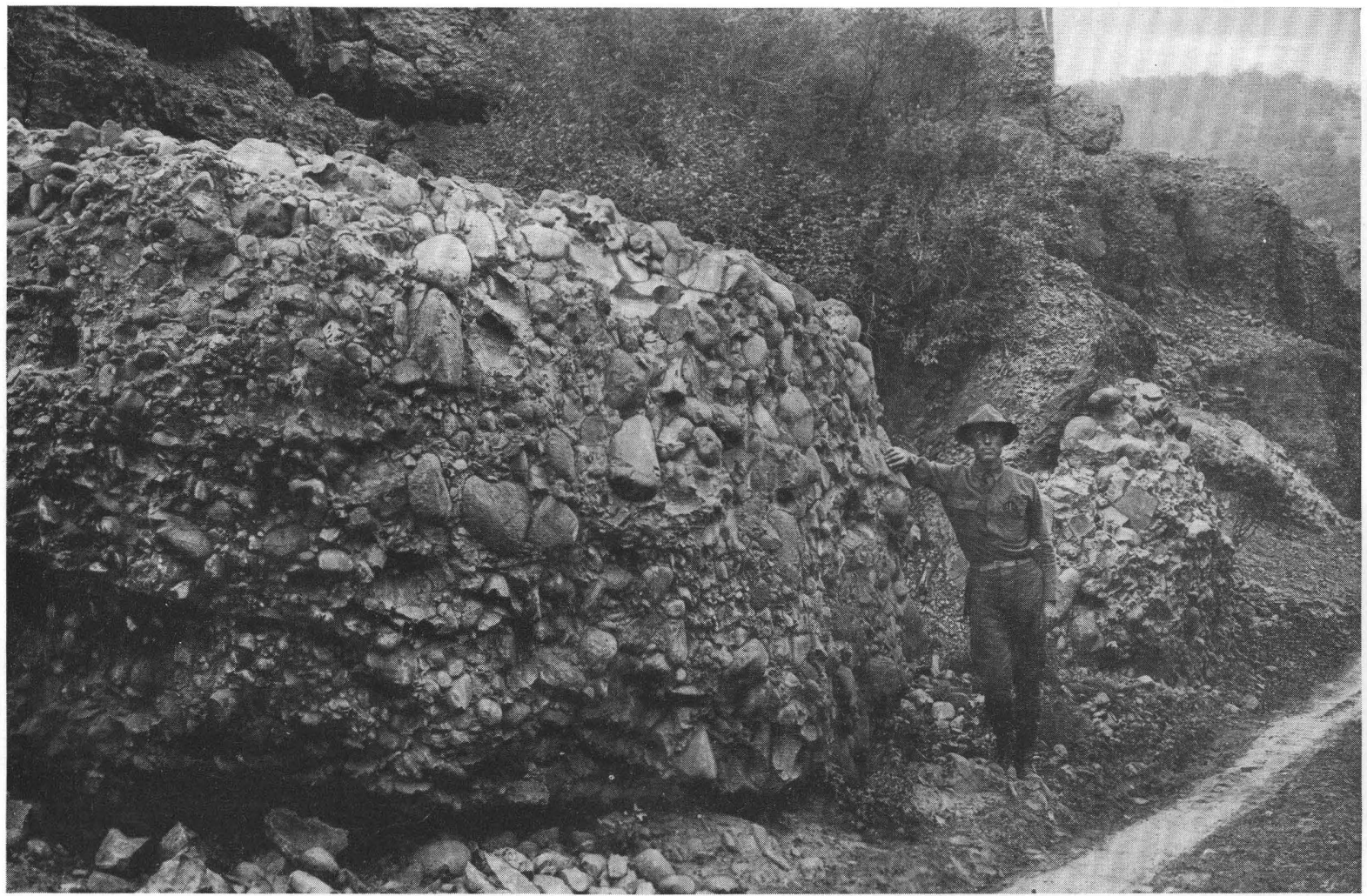

A. CONGLOMERATE OF THE PRICE RIVER FORMATION IN RED NARROWS, EAST OF THISTLE.

A representative display of the texture and outcrop of the lower part of the Price River in the western districts. The photograph was taken in 1924, and the ledge shown has since been completely removed in highway construction.

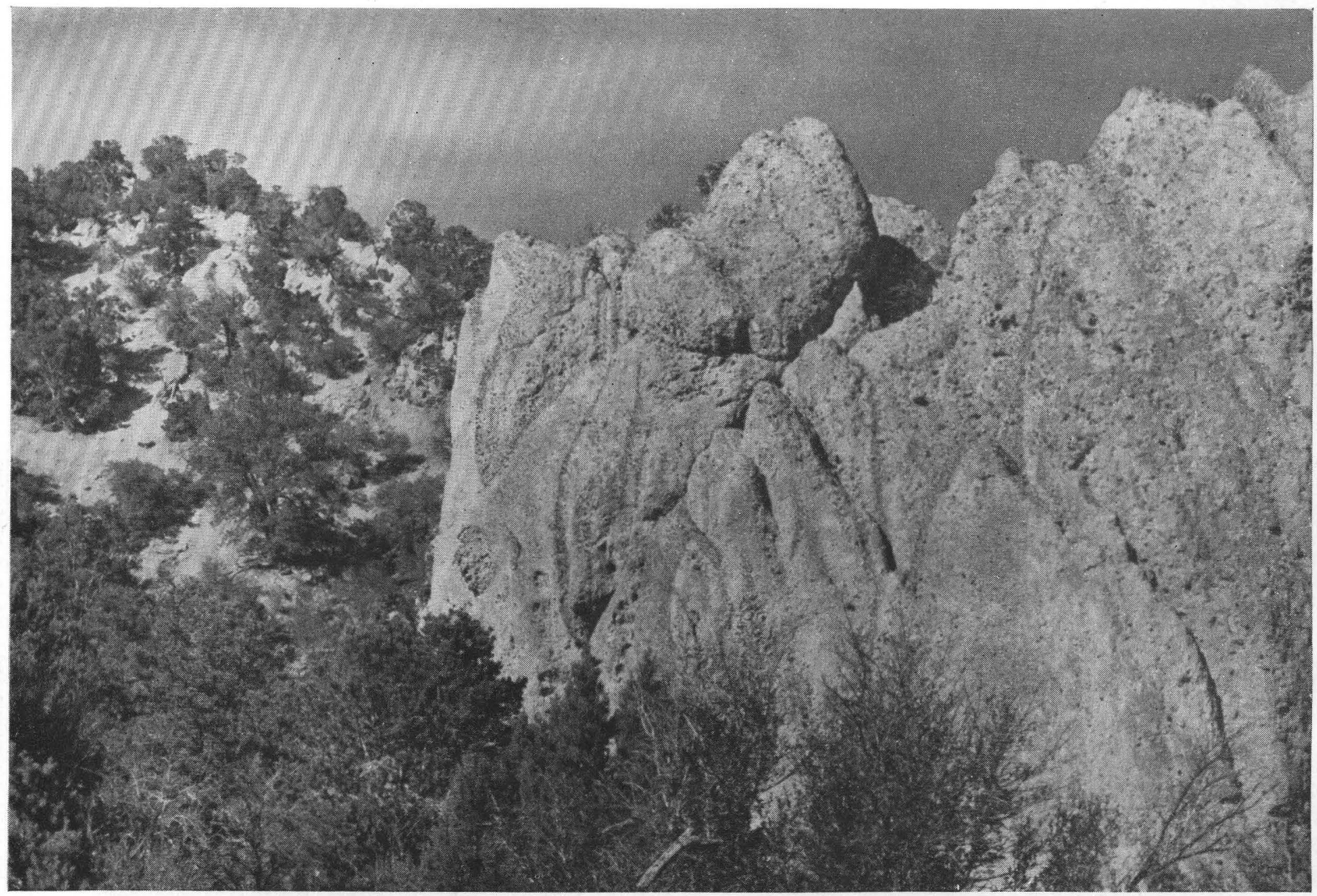

B. PRICE RIVER AND INDIANOLA STRATA ON HJORK CREEK.

Massive basal Price River, nearly vertical, on right; Indianola, dipping $60^{\circ}$ into angular unconformity, on left. The exposed vertical surface of the Price River in center is the basal part of the formation. The Indianola strata are the uppermost of the section given in the text (p. 130). 


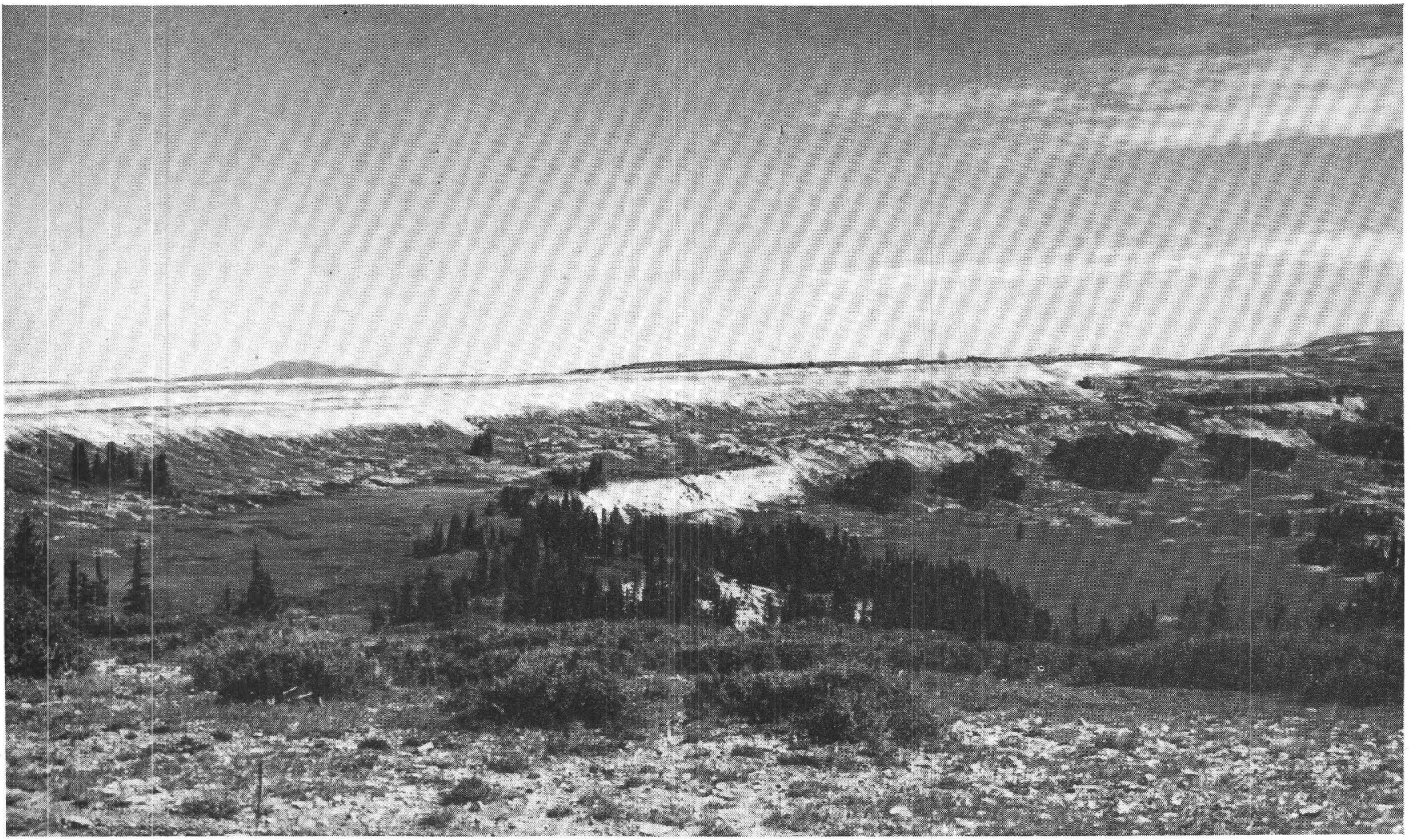

A. FlagstafF Limestone ON CREST OF WASATCH PLATEAU.

View northwest across the top of the south-central part of the plateau, at an altitude of about 10,500 feet. The flat divide here is held by a strong bed of silicified limestone, topmost Flagstaff; the base of the formation is some distance to the right, outside the field of view. The southern end of the Wasatch Mountains, about 50 miles distant, is visible on the skyline at the left.

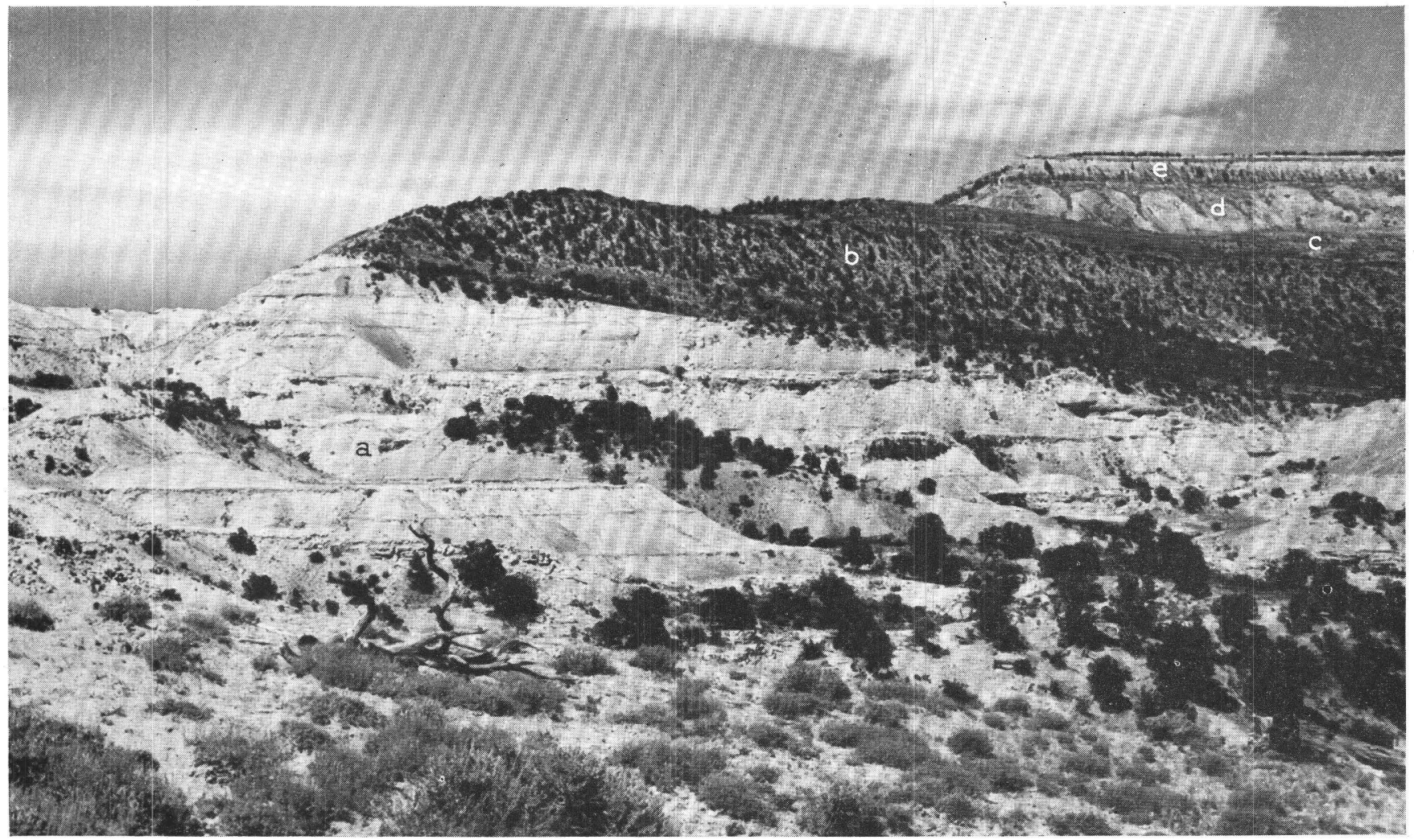

B. NORTH HORN FORMATION AT TYPE LOCALITY.

Southwest spur of North Horn Mountain, looking north. The dinosaur-bearing zone (unit 4 of section given in text, p. 133) is exposed to left and in center (a); unit 3 (b) forms vegetated spur, unit 2 (c) bench and slopes above, and unit 1 (d) steep slopes beneath the Flagstaff limestone (e), which caps the mountain. 


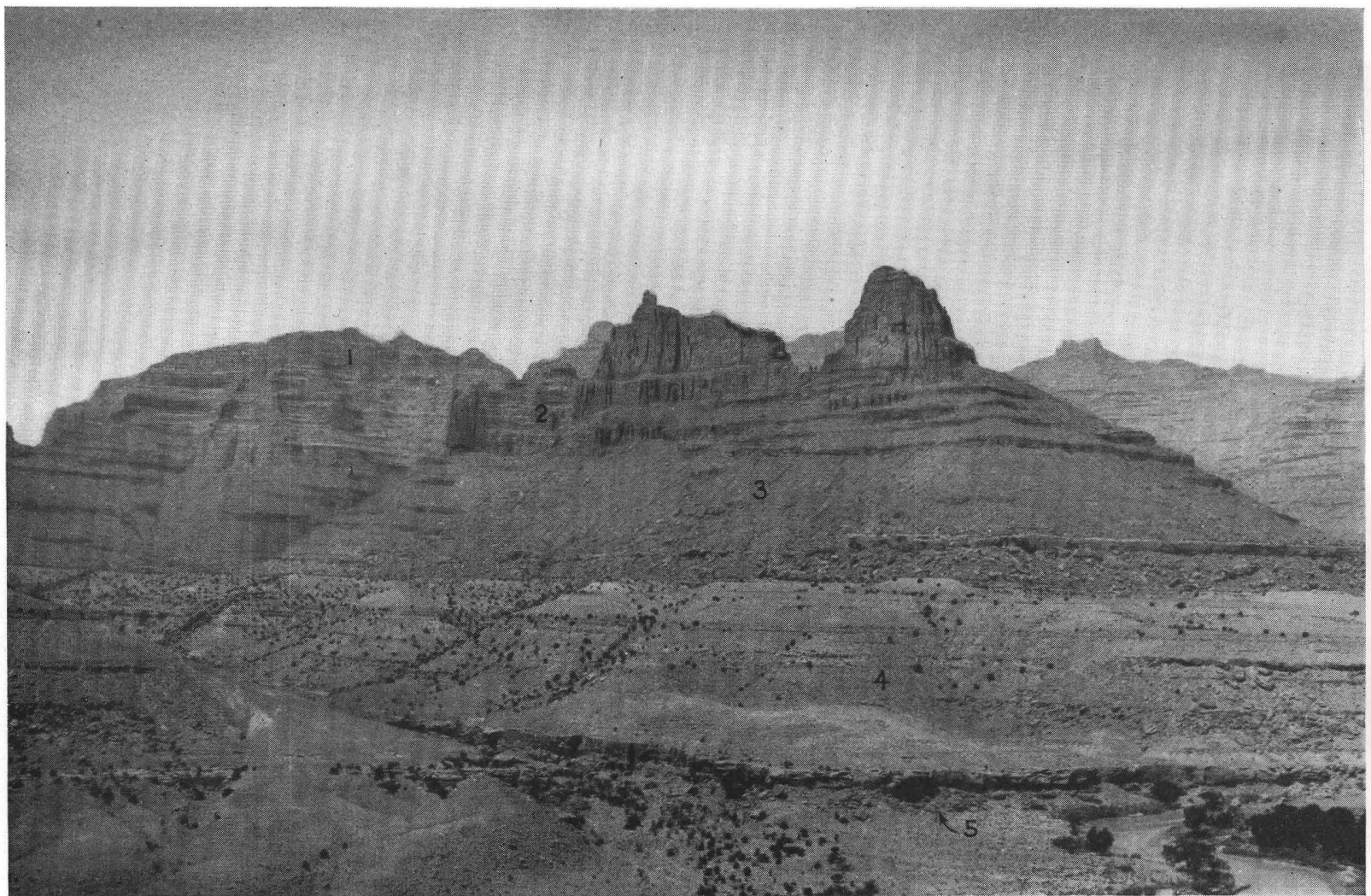

A. COLTON AND NORTH HORN FORMATIONS IN GREEN RIVER CANYON.

View northwest from a point below the mouth of Desolation Canyon. The river is visible in the lower right corner. The units are numbered to correspond with the section given in the text (p. 140): 1, 2, 3, Colton formation; 4, North Horn formation; 5 , Tuscher (?) formation.

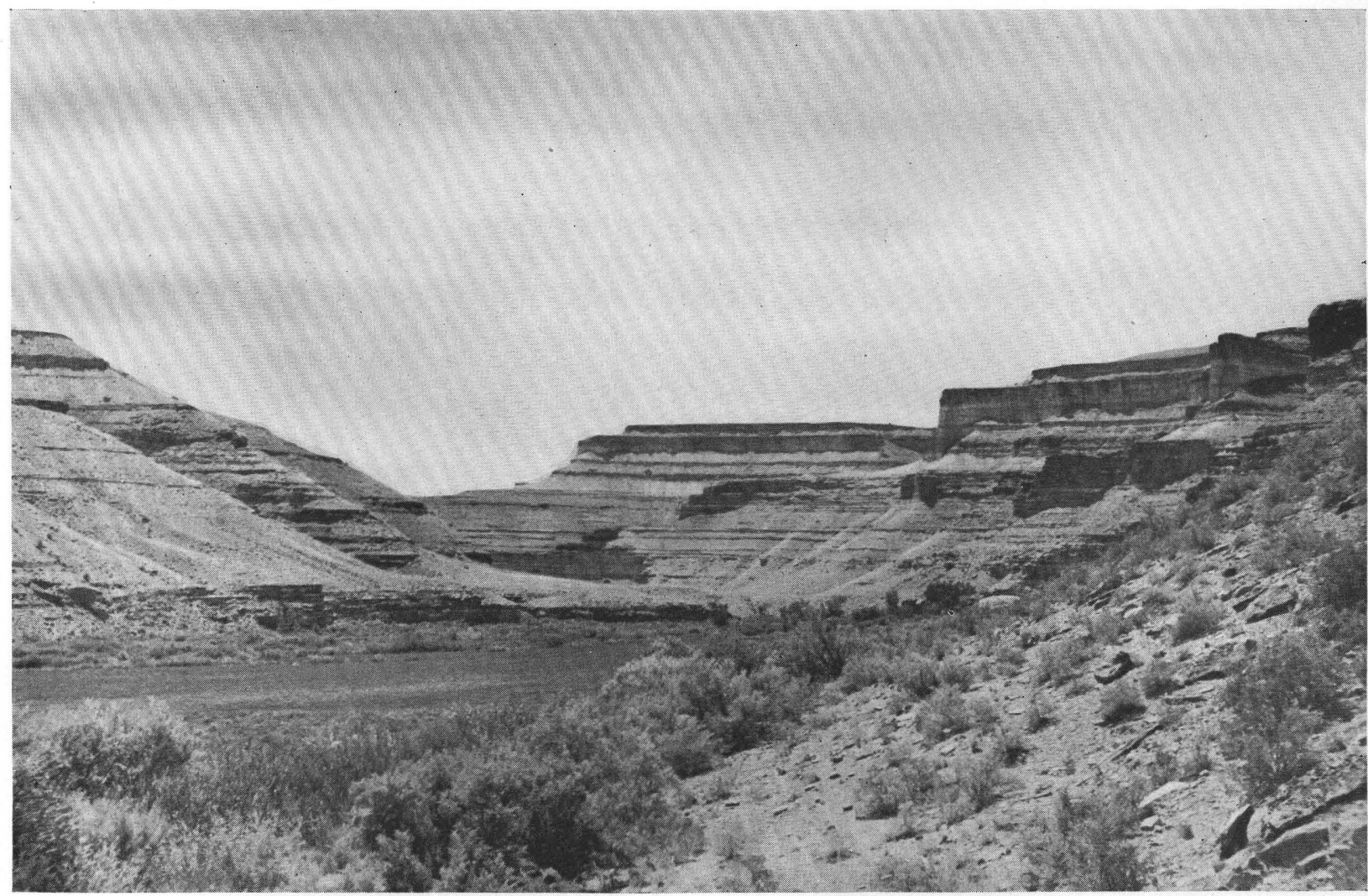

B. GREEN RIVER STRATA ON MINNIE MAUD CREEK.

A characteristic view of the evenly bedded lacustrine shales, marlstones, and other beds in the lower part of the Green River formation. 


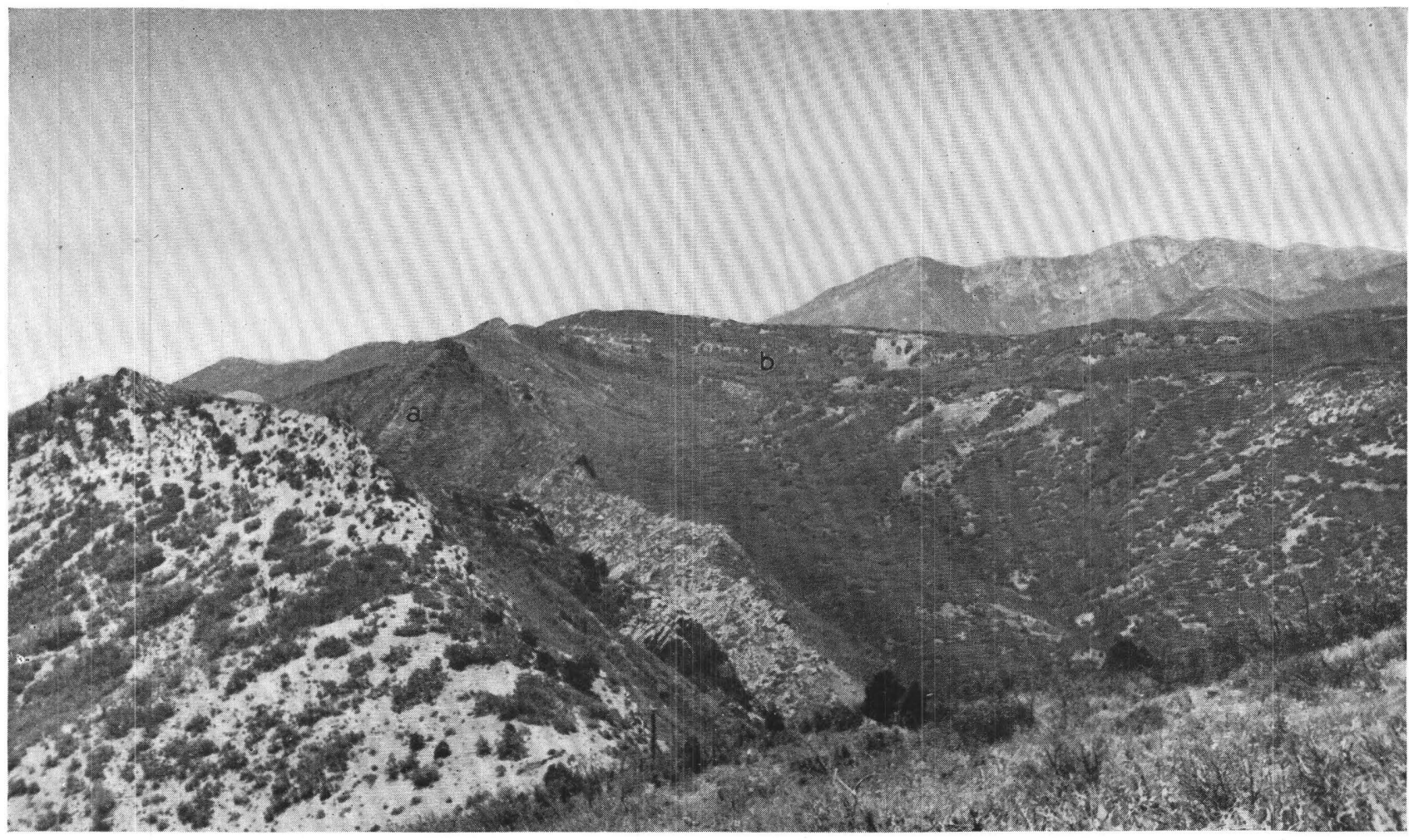

A. NORTH HORN FORMATION IN EAST FRONT OF WASATCH MOUNTAINS A'T THISTLE.

View southwest from bench above and north of Thistle. Rocks on left (a) are Jurassic, dipping steeply east in a hogback, part of foothills of late Cretaceous Wasatch Mountains. They are unconformably overlain by sediments of North Horn formation (b), nearly horizontal, filling ancient drainage chan
Price River formation may be present, covered, in lower part of present hollow. Crest of Wasatch Mountains forms right skyline.

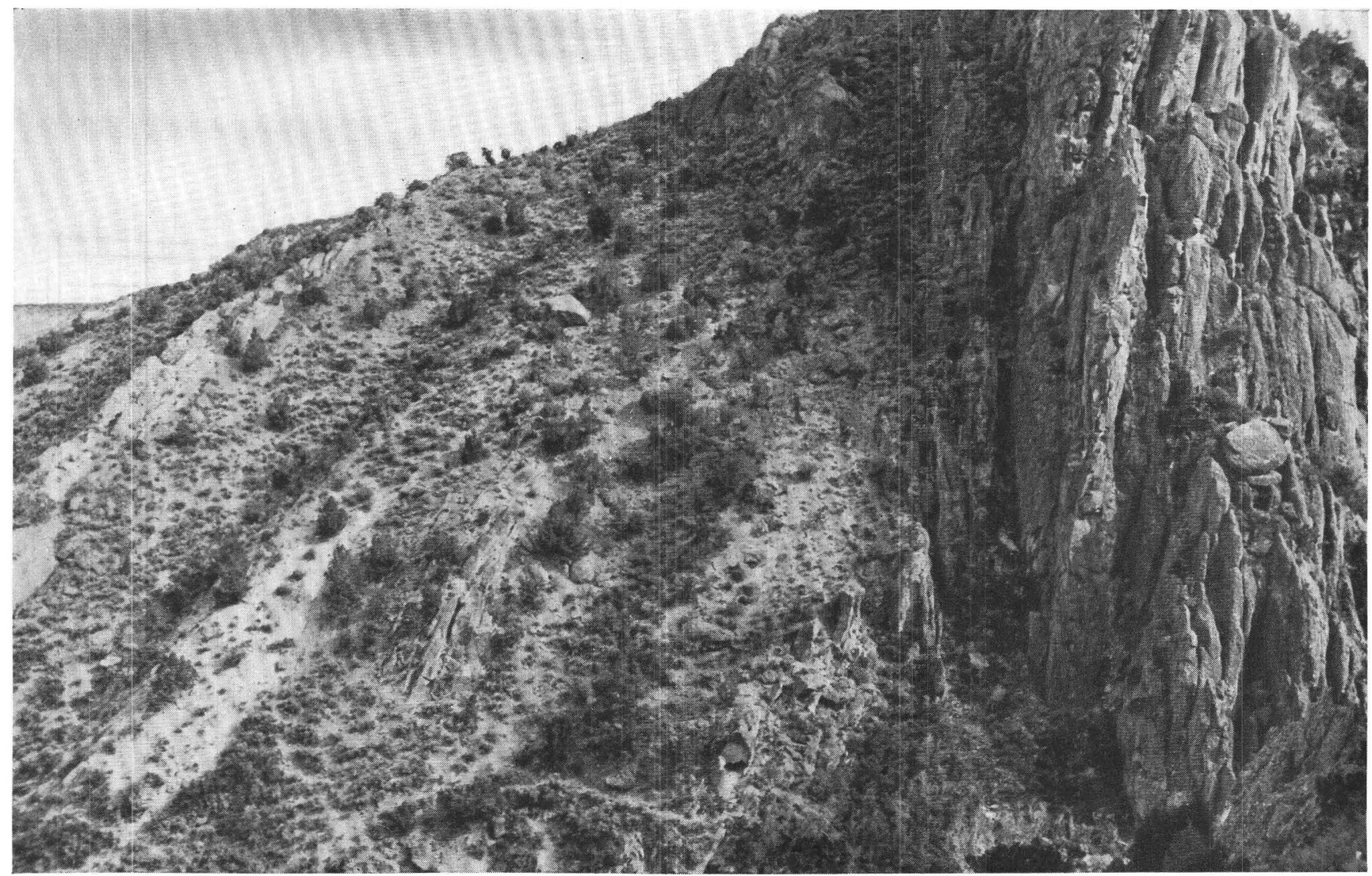

B. PRICE RIVER-INDIANOLA CONTACT NEAR WALES.

View south across gap in east front of Gunnison Plateau west of Wales. Vertical beds of Price River on right. Indianola, overturned, dipping about $35^{\circ}$, on left. 


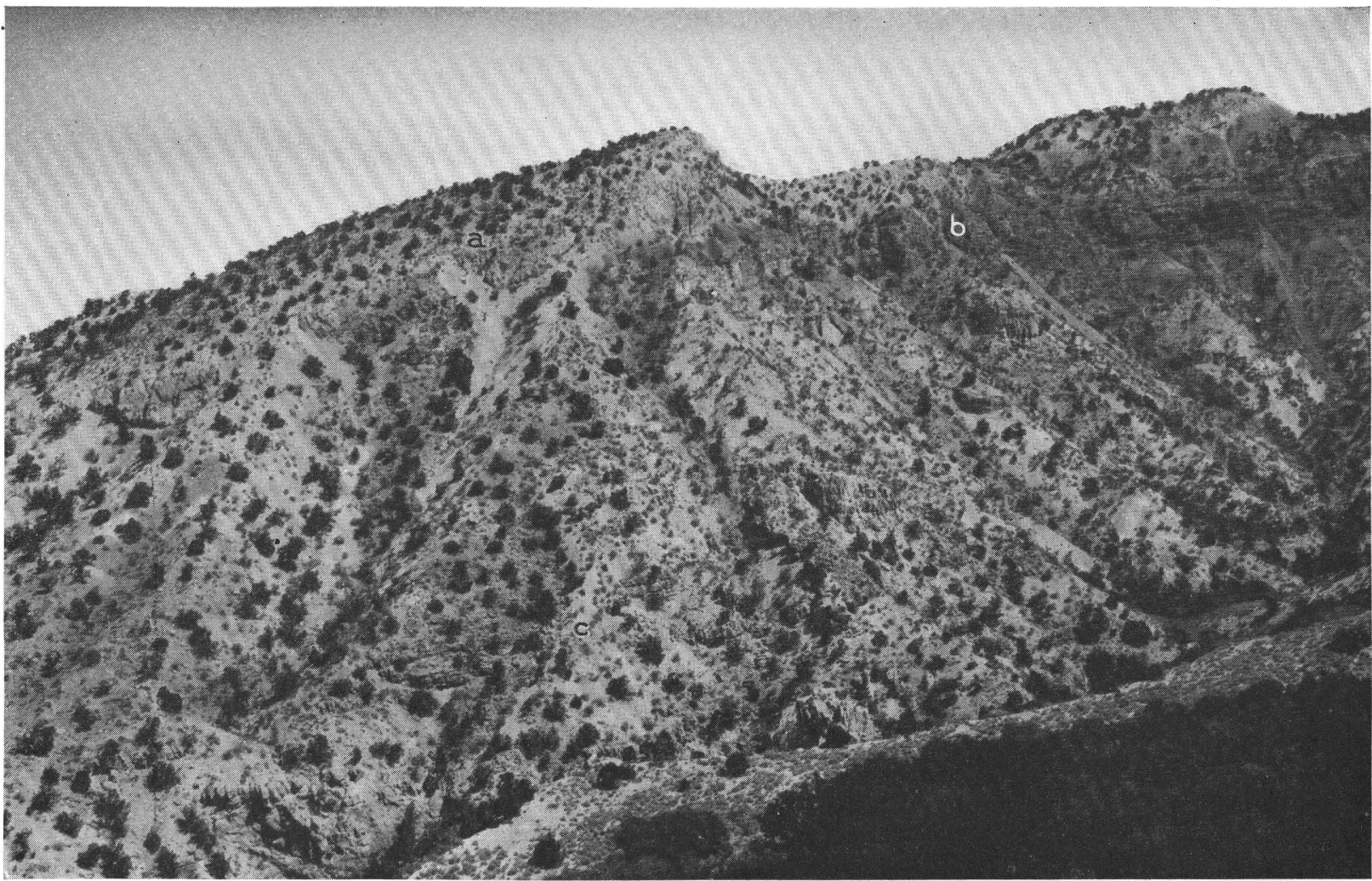

A. FLAGSTAFF-NORTH HORN UNCONFORMITY IN SIXMILE DISTRICT.

View north across gulch just south of Sixmile Canyon. The Flagstaff (a) is at the sky line, dipping about $40^{\circ} \mathrm{NW}$. and truncating the nearly horizontal beds of the underlying North Horn formation (b). 'The Price River formation (c) is visible in the bottom of the gulch. 'The lower angular unconformity over the Sixmile Canyon sandstone is out of sight to the left.

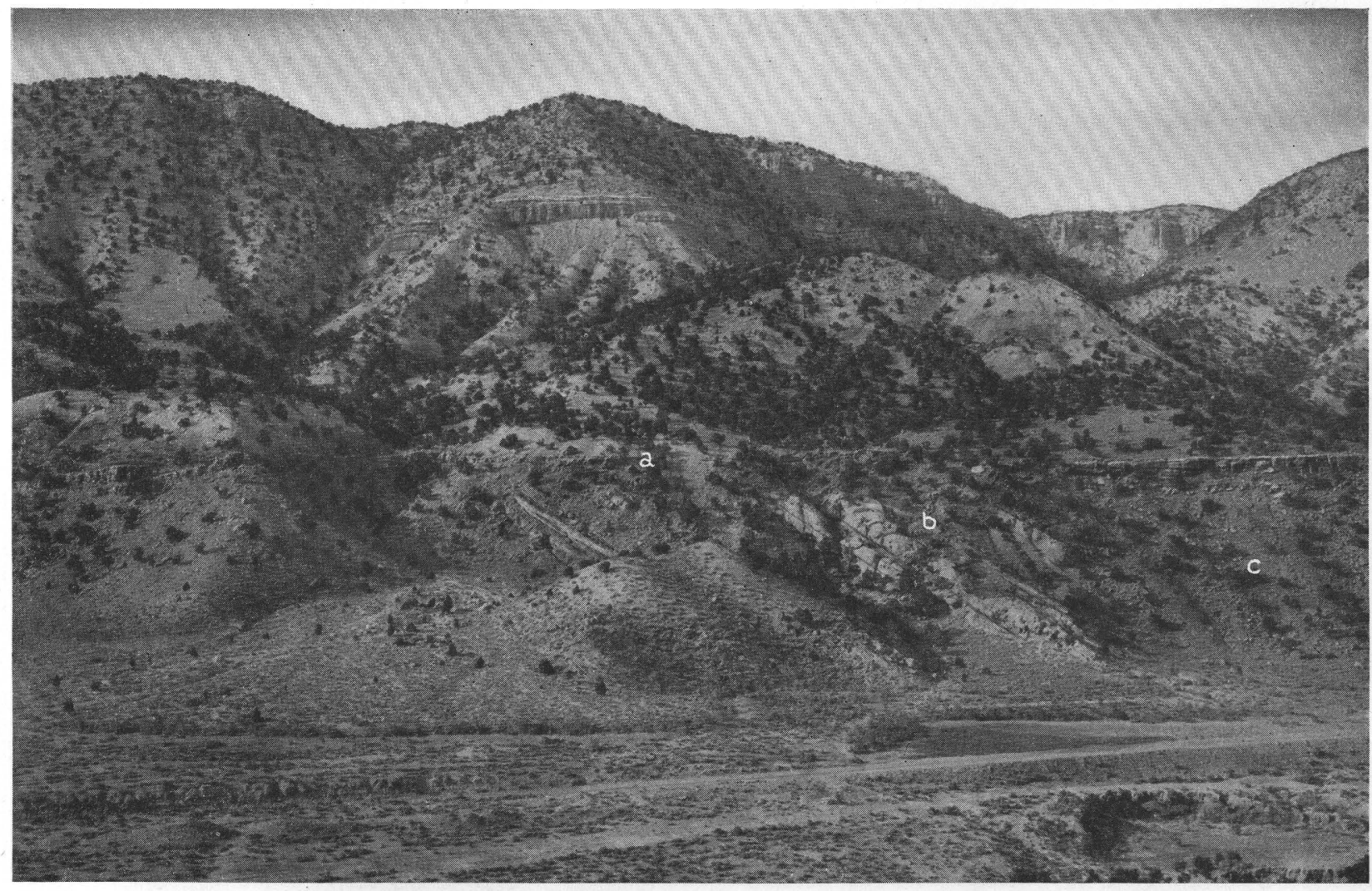

B. ANGULAR UNCONFORMITY IN SALINA CANYON.

View north across the canyon about 5 miles east of Salina. The upper rocks are all shales and limestones of the Flagstaff; the dark horizontal bed (a) near the mildde is red calcareous siltstone, basal Flagstaff. Beneath it are sandstone and shale of the Sanpete (b) and Allen Valley (c) formations, dipping about $30^{\circ} \mathrm{E}$. 
sive conglomerates of Echo Canyon. It is probable, however, that he was not aware of the heterogeneity in the assemblage thus defined, and especially of the lack of unity between the lower conglomerates and the strata at Wasatch station. In any event it is not the purpose of the present discussion to reach a conclusion in the matter, but rather to state certain elements of the general problem. In the opinion of the writer the name Wasatch should not be abandoned without more thorough study of the type area than has yet been prosecuted.

Nevertheless, to turn to the question immediately in hand for central Utah, with the general status of the name in such uncertain condition it seems hardly wise to attempt to identify Wasatch strata in the Wasatch Plateau and surrounding areas. The former upper member of the Wasatch formation in this region, therefore, is given a new name, the Colton formation, as defined below. The term "Wasatch age," as used in this report, means the general lower Eocene time division approximately equivalent to the Sparnacian of the European scale.

\section{COLTON FORMATION}

\section{DEFINITION, GENERAL CHARACTER, AND RELATIONSHIPS}

The strata formerly classified as the upper member of the Wasatch formation are here designated the Colton formation. The formation as thus defined consists of the beds in the hills north of Colton between the Flagstaff limestone and the Green River formation. These are gray, pepper-and-salt sandstone, greenish-buff sandstone, and siltstone that commonly weathers golden brown, and shale ranging from deep red to variegated and gray in color. Above Kyune, 2 miles east of Colton at the head of Price Canyon, the formation is almost exactly 1,500 feet thick, and the contacts, top and bottom, are clearly defined; the red beds and the sandstone rest on an even surface of Flagstaff limestone, and the white to gray shale of the Green River formation overlies red beds of the Colton with slight gradation. The Colton strata, individually irregular and discontinuous, are of flood-plain and channel origin, whereas the enclosing strata, regularly bedded, are lacustrine, and the striking contrast in color, a convenient criterion for recognition and mapping, represents a valid distinction between the two types of sediment. The stratigraphic limits of the Colton as thus given are of local value only; the strata of the two types intertongue extensively across the region, and the entire Colton formation west of Soldier Summit and the crest of the Wasatch Plateau grades into beds of Green River type, as shown on figure 18. In this region, therefore, the strata concerned evince most clearly their true character as lithologic, environmental units; chronologically the entire Colton is equivalent to part of the Green River formation.

In the Wasatch Plateau and surrounding territory the Colton formation is the highest of four units that contain variegated beds; the others are the Morrison (?) formation, parts of the Indianola group, and the North Horn formation. Locally, where the structure is complex, it is difficult to identify these units surely on lithologic grounds alone. Although no general rule can be formulated, it is worthy of note that the colored beds of the Colton are commonly different from the others in their greater monotony of color and in the predominance of deep reds. Especially noteworthy is the distinction between the Colton and North Horn formations, formerly thought of as two similar members of the same formation. The Colton displays, as a rule, very little delicate play of color, and as far as known it contains neither limestone nor coal. The North Horn contains not only variegated beds that range widely in color, with pale tints dominant, except locally in the western districts, but also abundant limestone in places and occasional beds of impure coal. The contrast between the two formations stands out clearly in the walls of Green River canyon, as may be seen in plate $23, A$.

\section{DISTRIBUTION}

West of the type locality the Colton formation grades laterally into beds of Green River type, as described above. To the east it is extensively exposed in the Tavaputs Plateau. In the main body of the Wasatch Plateau it is almost entirely absent, and in the summit areas the Flagstaff is the highest unit exposed. At one locality, however, in sec. 7, T. 19 S., R. 6 E., Salt Lake Meridian, there are variegated beds above the Flagstaff in the western part of the Joe's Valley graben ${ }^{72}$ that may be part of the Colton formation. On the west flank of the plateau the formation is present at the base of the Wasatch monocline in many areas between Salina and Mount Pleasant, and it is locally present in the Gunnison Plateau. In these western districts there is abundant evidence of intertonguing with both Green River and Flagstaff, and in large parts of the Gunnison Plateau the Colton seems to be absent.

\section{AGE AND CORRELATION}

The only fossils so far found in the Colton formation are a few freshwater mollusks, identified by Reeside as members of the traditional Wasatch fauna. The same strictures as those applied to the interpretation of such fossils in the underlying formations might here be suggested, but for one important fact-the collections from the Colton contain none of the species found in the North Horn and Flagstaff that originally cast doubt on the Wasatch age of those strata. There is thus at present no paleontologic evidence to show that the Colton formation is not of Wasatch age (lower EoceneSparnacian of the European scale); nor, on the other hand, is there any paleontologic evidence to prove that it is Wasatch. No trace of vertebrate remains has been found in the Colton strata, even after close examinatica of many excellent outcrops.

The physical evidence is likewise uncertain. The nearest localities at which Wasatch vertebrates have been found are in southwestern Wyoming, where Cope first discovered fossils in the type Wasatch of Hayden, and in western Colorado, where Patterson ${ }^{73}$ has reported the Hyracotherium (Eohippus) fauna. The relations between the Wasatch strata of these localities and the Colton of central Utah are not known, and considering the demonstrated complexity of stratigraphic relations in this part of the column where it has been studied in detail, comparison of sections seems futile. Without attempt at reviewing the available evidence, it may simply be said that the Colton formation of central Utah is possibly Wasatch in age.

\footnotetext{
72 Spieker, E. M., The Wasatch Plateau coal field, Utah: U. S. Geol. Survey Bull. 819, pl. 32, 1931. In this publication neither the Flagstaff nor the overlying beds at the locality mentioned were separated from the Wasatch as then defined ; at the time when the locality was mapped ${ }_{73}$ Patterson, Bryan, op. eit.
} 


\section{GREEN RIVER FORMATION}

The term "Green River formation" as here used departs in no important sense from current usage. Such new facts as might properly be set forth in this paper are given in the descriptions of the Flagstaff and Colton formations.

\section{RECONNAISSANCE EAST OF WASATCH PLATEAU WEST TAVAPUTS PLATEAU}

In 1934 the writer examined in brief reconnaissance the country east of the Wasatch Plateau and north of the Book Cliffs as far as Green River, to trace out the formations here described and connect them with a section earlier measured on Green River. Although not so complete as had been planned, the work yielded a considerable body of fact that is best presented here, along with the closely related information on central Utah. It is separated from the foregoing because of its more general nature. The stratigraphic relations observed are outlined in figure 18.

Between Price Canyon and the country east of Sunnyside, roughly 30 miles along the Book Cliffs, the Price River formation shows only minor variations in thickness and no important change in lithologic character; in general appearance at the outcrop as well as in details of lithology the formation in the Sunnyside district is the same as that at the type locality, possibly excepting the presence of somewhat finer-grained sandstone in the Castlegate member. On Green River, however, as shown in the section given farther on, the Castlegate is notably finer-grained, the beds above it are marine, and between these beds that are clearly identifiable as Price River and the North Horn formation there is a conglomeratic sandstone that appears to have no counterpart in the section of the western Book Cliffs. One aim of the reconnaissance was to discover the relations between the beds of the two sections, but the change was found to occur in country too rugged and difficult of access for the facilities available.

In the western stretch of the Book Cliffs the North Horn formation undergoes no important lithologic change, but decreases notably in thickness, as shown in figure 18. The Flagstaff limestone, about 600 feet thick in Price Canyon, vaguely separable from the North Horn formation but sharply set off from the overlying Colton, continues eastward without notable change from Colton as far as the main highway along Willow Creek northeast of Castlegate; farther east there is intertonguing in which about 300 feet of limestone and shale change to red shale and sandstone of the Colton type. Still farther east all that remains of the Flagstaff is a calcareous zone containing only a few well-defined limestone beds; this zone was traced as far as Sunnyside, where it is a barely recognizable remnant.

For about 20 miles east of Colton the Colton-Green River contact is regular, with no important intertonguing. In the first 12 miles of this stretch the contact is easily traceable in the hills north of the old Colton-Duchesne road, but farther east it crosses a very rugged divide to the headwaters of Minnie Maud Creek, in the vicinity of which there may be some intertonguing that has escaped notice; however, as well as could be determined in reconnaissance, not much intertonguing is possible. Along the upper reaches of Minnie Maud Creek, 20 to 25 miles east of Colton, a unit of brown sandstone and gray shale, flood-plain or delta sediments of the Colton type, appears about 200 to 250 feet above the base of the Green River formation and becomes 200 feet thick. This unit may be equivalent to the tongue of Wasatch strata described by Bradley ${ }^{74}$ in his section of the Green River deposits for Indian Canyon, not far to the northwest. Traced eastward down Minnie Maud Creek, this unit begins to contain red beds, becoming characteristically Wasatch, and about 33 miles east of Colton 100 to 200 feet more of Wasatchlike beds appear at the top. At this place a zone of red beds 50 to 75 feet thick occurs 300 feet higher in the Green River. A short distance farther downstream the whole interval here involved is more like the Wasatch than the Green River, with many thin beds of lacustrine material scattered through the section; the intertonguing is very intricate in detail. Traced toward Green River, these beds plunge under the surface and the lower course of Minnie Maud Creek is an imposing canyon in Green River strata. (See pl. $23, B$.) At the place where they plunge under, however, the beds are so closely similar to those originally called Wasatch in Green River Canyon that there is little doubt they are approximately the same. The contact veers southeastward toward Green River into the rugged country that was not penetrated in this reconnaissance. Unless there is some unexpected irregularity in this region, then, the contact between Colton and Green River is roughly 1,000 feet higher, stratigraphically, at the Green River than at Colton.

\section{GREEN RIVER CANYON}

In 1925 Reeside and the writer made a reconnaissance trip up the canyon of the Green River from Green River, Utah, to examine the late Cretaceous and early Tertiary rocks. Above the Castlegate sandstone member of the Price River the following section was found:

Section of post-Castlegate rocks on Green River between Desolation Canyon and Range Creek

Green River formation.

Feet

Colton formation:

1. Sandstone, deep buff to golden brown and brownish red; in massive ledges with interbedded red shale (estimated) _.

2. Sandstone, massive, buff to yellow, weathering brown; forms single cliff (estimated)

3. Shale, maroon, with interbedded buff to brown sandstone; irregular in detail but fairly regular in larger units (estimated)

Disconformity?

North Horn formation:

4. Shale, gray to variegated; sandstone, gray, brown, green; some conglomerate; zone of limestone 55 feet below top

Disconformity?

Tuscher (?) formation:

5. Sandstone, gray, cream, white, mostly coarse, in part conglomeratic; little shale

Disconformity.

Price River formation:

6. Sandstone, gray, medium (estimated)

7. Sandstone, gray, medium, with pockets of gray shale; forms ledges

8. Sandstone, buff; prominent regular beds of gray shale up to $10 \mathrm{ft}$. thick

9. Sandstone, buff, massive; irregularly bedded; few shale partings; forms persistent cliff, grades into unit 10

10. Sandstone, gray to brown; shale, gray to black; oyster reefs common, zone marine fossils $75-100$ $\mathrm{ft}$. above base; lower $75 \mathrm{ft}$. dominantly marine shale

Castlegate sandstone member.

Total

${ }^{74}$ Bradley, W. H., Origin and microfossils of the oil shale of the Green River formation of Colorado and Utah: U. S. Geol. Survey Prof.
Paper 168, p. 17, 1931. 


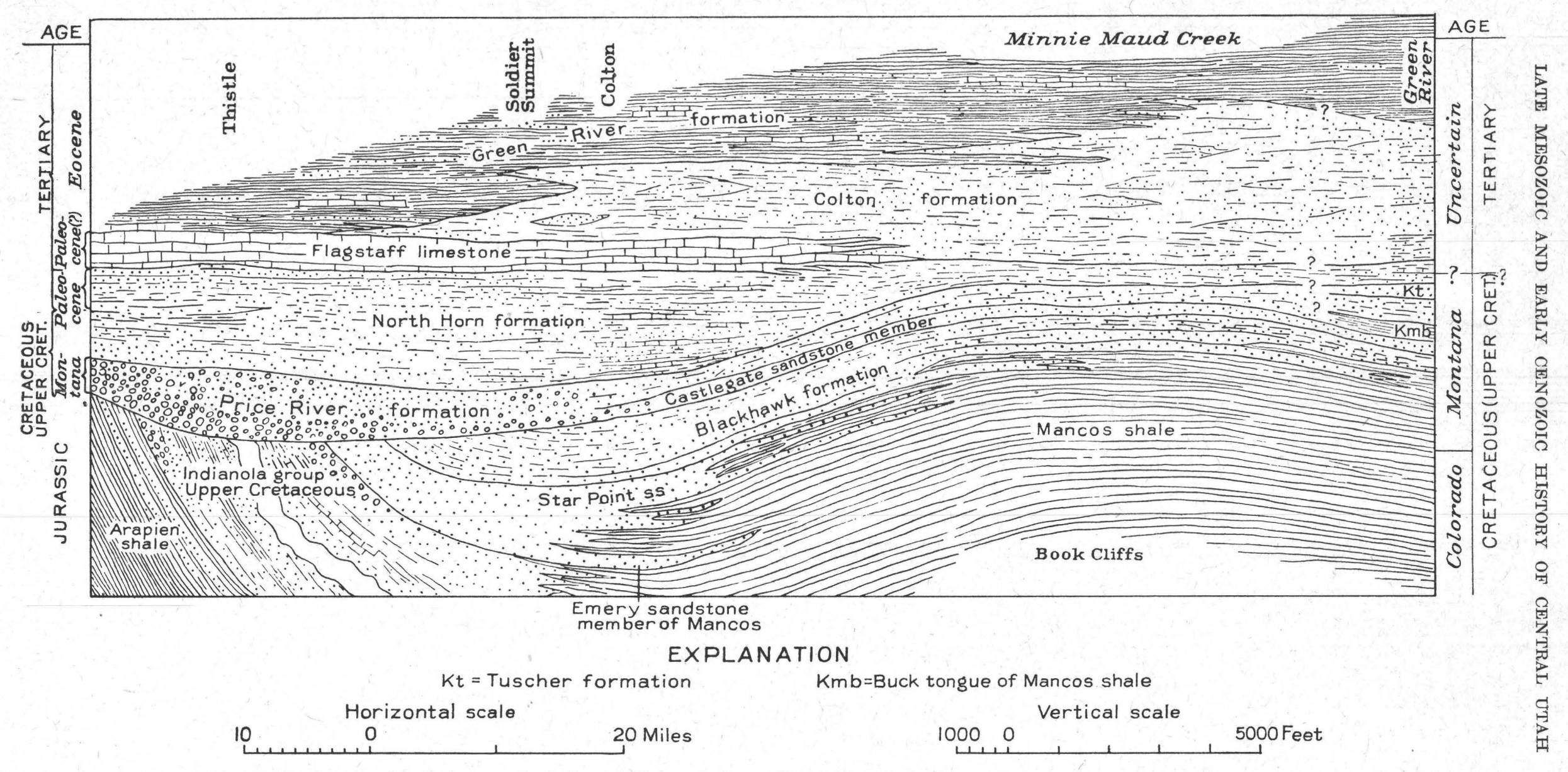

FIGURE 18. - Stratigraphic diagram, northern Wasatch Plateau to Green River. The Indianola group of this section may include the equivalent of the Morrison (?) formation as its basal part. The Morrison (?) is recognized near Thistle, out it has not been distinguished in the
district south of Thistle, which this section is intended to represent, and it is therefore not differentiated in this figure. 
Units 1 to 3 of this section are classified as the Colton formation. They correspond well in lithology and thickness with the Colton strata on Minnie Maud Creek, not far to the northwest. Unit 4 underlies these beds in sharp contrast; it corresponds well with the North Horn formation as seen in the Sunnyside district, to the west, and it may contain the equivalent of the Flagstaff. However, there is no definite zone of limestone at the top of the unit, and the only Flagstafflike bed is a gray limestone 15 feet thick, 55 feet beneath the top, underlain by shale containing thinner beds of limestone; these beds are like the limestones scattered through the North Horn formation in the western Book Cliffs, and when the section was measured they were not even thought of as possible Flagstaff. The whole unit contains much lacustrine sediment and is set off sharply from the overlying red beds of the Colton (see pl. 23, A) in a contact similar to that between Flagstaff and Colton farther west. Strong discontinuity is evident, and disconformity not unlikely.

Unit 5 is almost certainly the Tuscher formation ${ }^{75}$ of Fisher's section in the eastern Book Cliffs. Although it has not been connected by tracing with well-ascertained outcrops of the Tuscher to the south, it agrees so well in lithologic character, thickness, and stratigraphic position with the formation as defined by Fisher that the correlation is fairly sure. The place of the Tuscher in the Price River-North Horn succession of the western Book Cliffs, however, is not settled. Stratigraphic evidence on Green River, as well as that observed by Fisher in the Book Cliffs, suggests alliance of the Tuscher with the overlying rather than the underlying strata, and the writer's present conclusion is that the Tuscher is a coarse basal phase of the North Horn formation. This still leaves a question, however, concerning relationships to the west. Along Green River the Tuscher is disconformable on the underlying Price River formation and contrastively different, whereas in the western part of the Book Cliffs there is no apparent break between the Price River and North Horn formations. Throughout the eastern Book Cliffs the base of the Tuscher marks the first strong change in the Cretaceous section above the Mancos shale, and it would seem to signify a break of regional importance. This horizon must be located in the section of central Utah before the major outlines of the regional history can be clearly drawn.

Units 6 to 10 of the section constitute the upper member of the Price River formation. The upper part of unit 10 is the Sego sandstone member of Fisher's section and the lower is the Buck tongue of the Mancos. ${ }^{76}$

\section{CRETACEOUS-TERTIARY BOUNDARY PROBLEM}

\section{GENERAL CONSIDERATIONS}

The division between Cretaceous and Tertiary given in the foregoing stratigraphic scheme implies the assumption that this major boundary lies between the uppermost occurrence of dinosaurian remains and the lowermost occurrence of placental mammals. Although most students of this part of the stratigraphic column are probably coming to recognize this as the most logical dividing line between Cretaceous and Tertiary, there is not complete agreement, and to treat the matter as settled without any supporting discussion would constitute an unwarranted presumption. The problem has given rise to very extensive discussion, and yet in all the literature touching upon it there is remarkably little overt statement of the fundamental principles involved. The general questions of geologic chronology and subdivision, on the other hand, have been freely discussed in a considerable number of articles and books, especially in recent years, and there is abundant basis for consideration of general principles, even if the status of knowledge on many phases of the complex question is not fully clear. To the writer's knowledge no attempt at summary application of fundamental principles to the Cretaceous-Tertiary problem has been made. The new-found facts for central Utah contribute definitely to one phase of the subject, at least, in that they put the question of relation between the physical history and the fossil record in entirely new light.

For these reasons the writer ventures a discussion of the problem in the light of general principles-not an exhaustive treatment, nor yet a complete defense of the stand taken in this paper, but rather an examination of certain governing principles and concepts that seem to be crucial. In scientific investigation, and especially in such dominantly fact-finding activity as that of the geologist, it is worth while to pause occasionally in review of the fundamental basis on which results are being built up, and even in critical examination of elementary principles or postulates that seem virtually axiomatic. Too often familiarity with given lines of procedure leads to acceptance of concepts, methods, and interpretations without rigorous understanding of the nature of the basis on which they really rest. Especially does this tend to be true with respect to controversial subjects such as the present one, essentially the Laramie problem, in which part of the disagreement has arisen over elements of the evidence for which the fundamentally logical values have apparently not been thoroughly scrutinized.

The Laramie problem, one of the famous issues in the history of North American geology, has been sufficiently reviewed, ${ }^{77}$ and requires no summary here. It is enough to recall that the discussion, starting with sweeping assignments of all western coal-bearing strata to either Cretaceous or Tertiary, and then centering on the paleontologic and paleobotanic evidence, began in later years to involve the physical evidence, especially the existence and interpretation of unconformities and the attempt to locate in the stratigraphic column the horizon of the major orogenic episode. Probably most geologists agreed in the concept that the great disturbance marked the close of the Mesozoic era, ${ }^{78}$ and some held that profound orogeny must be world-wide in effect, hence simultaneous; furthermore, that such orogeny, in its controlling influence on geographic and biologic conditions, must produce strong widespread punctuation in the record, and therefore must logically be recognized as the prime basis for major chronologic subdivision. Under this concept the location of the major physical break in the column was of prime importance, but in the sections that afforded good fossil evidence the physical relations were the source

\footnotetext{
${ }^{75}$ Fisher, D. J., The Book Cliffs coal field in Grand and Emery Counties, Utah : U. S. Geol. Survey Bull. 852, p. 20, 1936.

Fisher, D. J., op. cit., pp. 15-16.

For summary and bibliography see the following papers:

Knowlton, F. H., The Laramie flora of the Denver Basin: U. S. Geol. Survey Prof. Paper 130, 1922. Dobbin, C. E., and Reeside, J. B., Jr., The contact of the Fox Hills and Lance formations: U. S. Geol. Survey Prof. Paper 158, pp. 9-25, 1929. Russell, L. S., The Cretaceous 26, sec. 4, pp. 121-156, 1932 . o p. 647,1914 ; and textbooks of historical geology.
} 
of much disagreement. Unconformities between zones of different fossil content, argued as valid division lines and held by some geologists to be of prime physical significance, have been shown by Dobbin and Reeside ${ }^{79}$ to be susceptible of quite different interpretation. Among lines of evidence needed for adequate survey of the problem, a most important item was precise and certain determination of the position in the stratigraphic column of the major episode or episodes in the Laramide orogeny.

The evidence now available in central Utah meets this need for part, at least, of the North American Cordillera. The major Laramide folding in this area took place a long time before any of the important changes in the fossil record that have been argued as division markers, and the relative significance of these two types of event must be evaluated in a decision on the boundary problem. Distinct and independent, instead of simultaneous and interrelated, they cannot both be given weight; and as the Utah evidence is scanned the choice seems naturally to fall on the paleontologic basis, for the time of orogeny now ascertained lies too far within the bounds of typical Cretaceous to seem possible as a division marker. This decision involves an assumption as to what constitutes typical Cretaceous, a concept that is briefly examined, in another connection, below. If it be granted for the moment that typical Cretaceous can be recognized and that the upper part of the Montana group is clearly of that type, then if the boundary is to be placed at an upper limit of typical Cretaceous the earliest strong Laramide orogeny in central Utah falls out of consideration as a boundary marker. More than that, the orogeny came at a time that witnessed no marked faunal change and no physical change other than the folding itself and its immediate effects, which were local. It would seem to be ruled out as a marker of anything significant in either the stratigraphic succession or the time scale as generally conceived.

There were other strong movements, however, in the Laramide belt during the passage from typical Cretaceous to typical Tertiary, notably the one in the Rocky Mountains of Montana and Alberta that probably came between the Fort Union and the Wasatch. The question might still be raised whether this movement provides significant basis for a division, despite the fact that the anomalous position of the central Utah orogeny weakens the thesis in general and at least adds to the application of the principle another complication, that of differentiating between orogenies as to their relative significance.

\section{QUESTION OF BASIS FOR TIME DIVISION}

It might be well here to raise the question, Is there, after all, a valid general basis for the subdivision of geologic time? And secondarily, if there is a basis usable to characterize the larger subdivisions, can it be applied to the exact determination of boundaries? Logically, such basis ought to be some fairly definite expression of natural law, but when the geologist searches the data of his science he finds no well-established law to guide him; rather, he finds only the cumulative result of empirical experience in which many elements conflict. Originally the plan of the time scale did imply natural law-a comprehensive generalization that united profound, world-wide physical disturbances with sweeping changes in the living world, and that postu- lated a cyclic periodicity. So comprehensive a generalization would make without question a most satisfactory basis for subdivision. When the available data are assembled,,$^{80}$ it is evident that the time pattern of the earth's orogenic performance does not match the pattern of subdivision based on fossil succession. The paleontologic evidence, critically examined, yields uncertainties amply emphasized in the boundary disputes that have arisen over every important division in the scale. These uncertainties have arisen in large part out of the attempt to continue the use of fossils along lines based on older concepts of sweeping change, in the face of newer knowledge that is out of harmony with those concepts. In general, as the body of geologic fact has increased, as gaps have been filled and crudities replaced by refinement, the appearances of regularity and uniformity on which many of the older concepts were founded have faded away.

As to the relative values for subdivision inherent in the physical and organic records, to the extent that past experience may point the way, decision between the two is implicit in the standard scale against which the orogenic succession is laid; in the development of this scale the fossil evidence has been paramount. However, this does not in itself necessarily deny to the orogenic record any place in the formulation of boundaries, and the point may not be dismissed without some consideration of the facts now available.

Before considering specifically certain pertinent features of the physical and organic records, it is important to recognize the distinction between correlation and subdivision. Most existing discussion of the diverse evidence has laid stress on the question of validity for correlation. Validity as a criterion for subdivision is another thing, and the two have not always been carefully distinguished in discussions of boundary problems. A given criterion, granted it be valid for subdivision, must be accurately correlatable throughout the world, and without inquiring further, at this point, as to the special significance to be sought in a valid criterion for subdivision, it appears well to examine the values inherent in orogenic disturbances as regards contemporaneity.

\section{THE OROGENIC RECORD}

Stille ${ }^{81}$ and Bucher ${ }^{82}$ have come to the conclusion that the important orogenic pulsations of the earth's crust have been sharp, simultaneous over the world, and separated by much longer periods of quiet. If this is true, orogeny might provide the most accurate means of correlation yet available, and in light of the rather regularly increasing frequency of the pulsations toward the present, the pattern of orogenic succession might afford the most logical framework for a time scale.

That many of the orogenic episodes have been relatively short seems well established, although some whose age relations are well determined seem to have been drawn out over considerable periods of time. In order to determine this point it is obviously necessary to fix the date of a given orogeny within adequate time limits, and many that meet this requirement, such as the early Laramide and the pre-Flagstaff movements of this paper, were unquestionably much shorter in

'7 Dobbin, C. E., and Reeside, J. B., Jr., op. cit.

80 Stille, Hans, Grundfragen der vergleichenden Tektonik, pp. 154163 , Berlin, 1924 .

82 Bucher, W. H., The deformation of the earth's crust, pp. 414-416, ${ }^{82}$ Bucher, W.
Princeton, 1933 . 
duration than the intervening periods of quiet. It must be recognized, however, that most of the evidence on orogenic dates marshalled by Stille ${ }^{83}$ is inadequate to prove global episodicity; the ages of the limiting strata are generally too far apart. It must also be recognized that some orogenies, such as the mid-Cretaceous movement of this paper and the early Jurassic folding of east-central Nevada, ${ }^{84}$ seem possibly to have been somewhat protracted. In a comparative sense, however, even these movements were probably shorter than the intervening periods of quiet.

In a paper questioning the periodicity of diastrophism, Shepard ${ }^{85}$ has postulated essential continuity of orogenic activity since the pre-Cambrian. Shepard's argument against periodicity seems to be sound, and his insistence on the inaccuracy with which most orogenies are dated is thoroughly justified, but the evidence hardly demonstrates continuity-rather multiplicity. Evidence in support of episodic character has recently been brought out for a most important region, California, ${ }^{86}$ the exceedingly complex structural development of which might easily suggest continuity of orogenic process. In general, it seems a fair conclusion that orogeny has been for the most part episodic rather than protracted or continuous in nature.

Demonstration that the sharply defined episodes are simultaneous, however, rests finally on paleontologic evidence, which, as pointed out by Bubnoff, ${ }^{87}$ is itself not unimpeachable. It should further be observed that many of the episodes cited by Stille are by no means closely dated; some, perhaps, not reliably. For example, in his listing of the Laramide orogeny Stille ${ }^{88}$ accepts for the first movement in North America the age given by Blackwelder ${ }^{89}$ simply as the close of the Cretaceous. Bucher later cited, as indicative of the early Laramide movement, the unconformities at the base of the Colgate member of the Fox Hills sandstone in eastern Montana and between the Laramie and Arapahoe formations of the Denver Basin, correlating this break with the early Laramide movement of Europe as classified by Stille..$^{90}$ The correlation of the unconformities between Montana and Colorado has been shown by Dobbin and Reeside ${ }^{91}$ to be probably incorrect, and the contact between the Laramie and the Arapahoe formations has been shown by Lovering ${ }^{92}$ to signify no great orogenic movement, rather local uplift of little significance. Further, the LaramieArapahoe contact lies well above the horizon of the Fox Hills-Lance transition and is thus probably not contemporaneous with the Maestrichtian-Danian movement specified by Stille as the early Laramide. The dates of the movement in Europe cited by Stille as Laramide are in large part not closely determined, ${ }^{93}$ and this is true as well in other parts of the world. In order to show at a glance the value of the European evidence, the writer has prepared figure 19 according to the data given by Stille. In this alinement it is evident that the only place where the two movements assigned to the Laramide are accurately and certainly dated is in the Mons region, where the disturbances on the Artois axis were weak.

Further, Stille's assignment of the second Laramide movement ${ }^{94}$ does not coincide with the time of strongest Laramide movement in the Rocky Mountains of Montana. In the Mons region of Belgium this movement came, as cited by Stille, between the "upper Mons" (lower Thanetian of general usage) and the lower Lan-

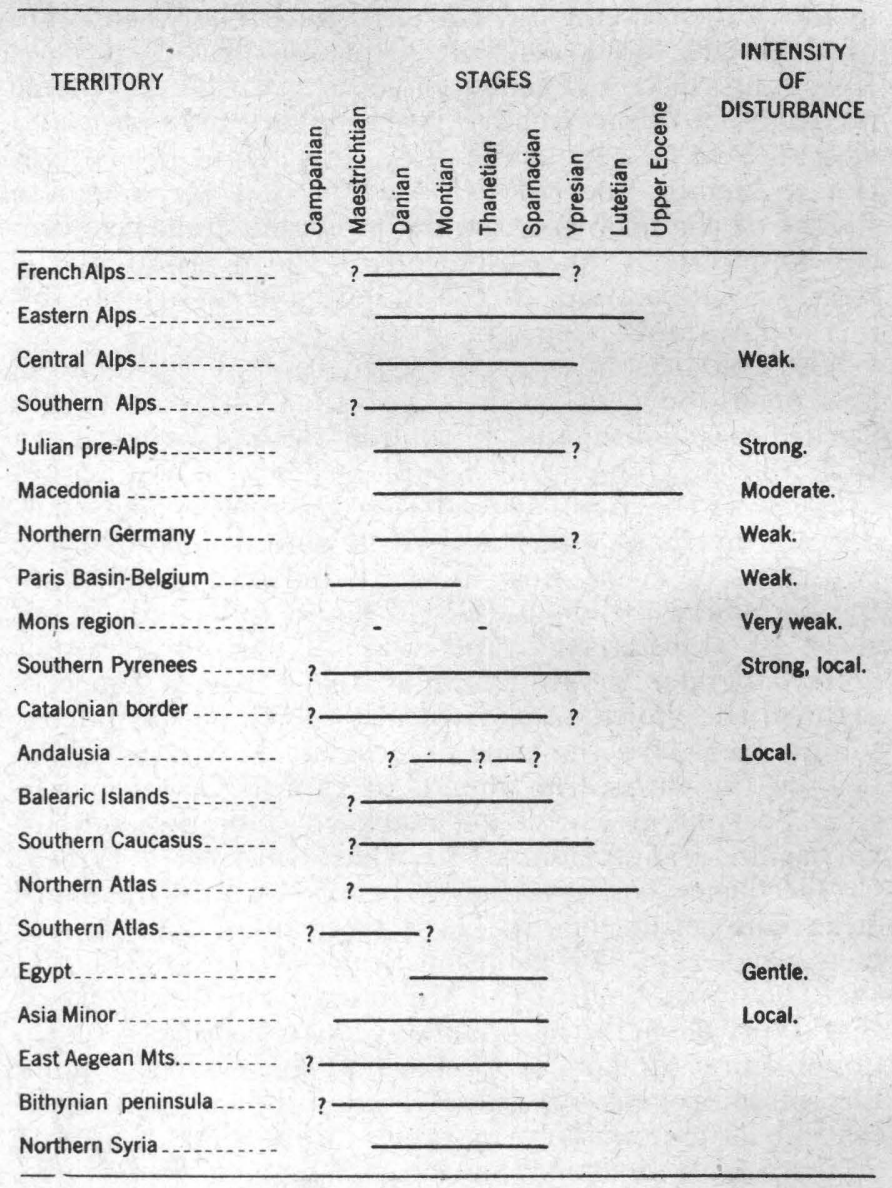

FrgURE 19.-Age determination of Laramide orogeny in Europe. The list includes only regions for which reasonably accurate stratigraphic data are available. The lines extend between the younge
folded strata and the oldest known nonfolded. After Stille.

denian (upper Thanetian or Cernaysian). Theșe stages, as well as they may be correlated with the North American section, are equivalent to the middle Fort Union and the Clark Fork, respectively, and in any event are earlier than the true Wasatch, or Sparnacian. ${ }^{95}$ In the Rocky Mountain districts of Montana and Alberta the major orogenic impulse came after the latest Fort Union (Clark Fork; upper Paskapoo of Canadian geologists ${ }^{96}$ ) and perhaps before the Wasatch, although the upper limit is not clearly proved to be any earlier than late Eocene. ${ }^{97}$ The discrepancy between these determina-

\footnotetext{
${ }^{3}$ Stille, Hans, op. cit., pp. $62-210$.
${ }_{84}$ Ferguson, H. G., and Muller, S. W., Early Jurassic orogeny in westcentral Nevada: Geol. Soc. America Proc. 1936, p. 71, 1937

${ }^{85}$ Shepard, F. P., To question the theory of periodic diastrophism: Jour. Geology, vol. 31, pp. 599, 602, 613, 1923.

Coed, K. D., and Holister, J. S., Struetural 作, $1691,1937$.

87 Bubnofi, S. Grundprobleme der Geologie, pp. 137-142, Berlin, 1931. 88 Stille, Hans, op. cit., p. 155.

Blackwelder, Eliot, Handbuch

pp. 62, 141, 159, Heidelberg, 1912. Dobbin, C. E., and Reeside. J. B.. Jr., The contact of the Fox Hills 1929

02 Lovering, T. S., Geologic history of the Front Range, Colorado: Colorado Sci. Soc. Proc., vol. 12, no 4, pp. 91-92, 1929.

${ }_{93}$ Stille, Hans, op. cit., pp. 156-162.

44 Stille. Hans, op. cit., p. 160.

${ }_{95}$ Woodring, W. P., and Gazin, C. L., in Stratigraphic nomenclature in the United States: 16th Internat. Geol. Cong. Guidebook 29, pl. 9 1932. Bubnoff, S., Geologie von Europa, vol. 2, pt. 2, p. 1020, table 12, Berlin, 1935.

The Cretaceous-Tertiary transition of Alberta : Roya Soc. Canada Trans., vol. 26, sec. 4, pp. 148-151, 1932. "Tr Fraser, F. J., McLearn, F. H., Russell, L. S. Warren, P. S., and Survey Mem. 176, p. 119, 1935. Russell, L. S., and Wickenden, R. T. D. An urey Mem. 176, p. 119,1930 . Trans., 3 d ser., vol. 27 , sec. 4, pp. 53-65, 1933.
} 
tions is sufficient to raise question concerning simultaneity. If there is inclination to allow for inaccuracy in the long-range stratigraphic correlation, it might be borne in mind that the Sparnacian mammals are probably more closely correlated between Europe and North America than are any others; ${ }^{98}$ and, as far as such paleontologic evidence is valid for correlation, it would seem to hold good in this instance. The correlation of the underlying Cernaysian with the Tiffany and Clark Fork beds of North America, as given by Matthew, ${ }^{99}$ seems likewise strong.

It should also be noted that the times of at least two out of three strong orogenic disturbances recently determined in the western United States appear to have no counterpart in Stille's table. The early Laramide movement described in this paper, rather accurately placed in the local section, came at a time which, even if not precisely referable to the European time scale, is clearly different from the two nearest in Stille's list. Of these the older, the Wernigeröde phase of the Subhercynian orogeny, ${ }^{1}$ is Santonian in age, corresponding to late Colorado (Niobrara) of the western American column, ${ }^{2}$ or the middle part of the Mancos shale in Utah; this correlation is fairly well established by characteristic marine faunas. The next younger of Stille's list, the "early Laramide," falls between the Maestrichtian and the Danian of the European scale, corresponding approximately to the upper limit of the Montana group in the American section, or the boundary between the Fox Hills and the Lance formations of the plains section. This horizon is not accurately located in the Utah section, but it certainly lies above the base of the Price River formation. The main Laramide folding of central Utah came between middle and late Montana times, probably in the late Campanian of the European scale. With adequate discount for uncertainty in correlation with the European section, this folding is unquestionably later than the Subhercynian and almost certainly earlier than the "early Laramide" movement of Stille.

The other two American orogenies that fail to agree are those reported by Ferguson and Muller ${ }^{3}$ for western Nevada; these fall in the Karnian stage of the Triassic and in the late Liassic stage of the Jurassic. Stille's grouping shows nothing for the Karnian, his early Cimmerian folding coming between the Norian and Rhaetian. ${ }^{4}$ For the Lias he records questionably a disturbance in the Donetz district, but as reported by Borissjak ${ }^{5}$ this folding preceded the upper Lias. Comparison with the Liassic folding of Nevada is not so clear as the others here given, because the Nevada folding seems to have continued through Liassic time, and the Donetz folding may coincide with part of it, but if the report is correct it came before the end of the Lias, the time of maximum disturbance in Nevada.

Another difficulty in the way of visualizing the significance of Stille's grouping is presented by the problem of distinguishing between true orogenic movements and warping of epeirogenic nature. Most of the instances of Laramide folding outside of North America are far from profound, and many involve only slight discordance. The writer is inclined to agree with $\mathrm{Pia}^{{ }^{B}}$ that such minor discordances, should they happen to occur at times of no great orogeny elsewhere, would be classed as epeirogenic. Stille's criterion ${ }^{7}$ for the discrimination between minor warping movements of orogenic nature and those of epeirogenic origin is to classify as orogenic those that occur at a time of strong orogeny elsewhere. This merely begs the question; the occurrence of such minor movements at times of orogeny may not be fortuitous, but if no other positive criteria are available for distinction from movements of truly epeirogenic nature, such occurrences add little to the argument for widespread contemporaneity of orogeny. At all events, to connect the epeirogeny causally with the orogeny does not help matters for the Laramide epoch, because the orogeny, as now known, began long before the general emergence of North America.

It seems that the hypothesis of orogenic simultaneity is not well enough established to be relied on either in correlation or the establishment of divisions in the time scale. This is not to say that simultaneity has not prevailed; obviously, if orogenic process is due to some pervading, nonsporadic condition of episodic character in the earth's internal mechanism, it might well be simultaneous. The fundamental cause of orogeny, however, is not well enough understood to serve as basis for such a superstructure of reasoning.

\section{THE EPEIROGENIC RECORD}

Epeirogenic movement would appear to fall in a different category from orogeny, empirically considered, in evaluation of bases for division. Although there have been orogenic disturbances within the time intervals occupied by the great epeirogenic movements that have caused extensive recessions of the sea, inspection of the orogenic chronology presented in this paper reveals little or no evident relation between the two types of movement for the late Mesozoic and early Cenozoic of North America. If the orogenic succession affords no immediately acceptable basis for subdivision, perhaps the broader and slower pulses of epeirogenic movement might embody some feature which would serve to provide a purely physical basis.

Especially does this seem worthy of consideration for the division between Cretaceous and Tertiary, which is often thought of by geologists as the most clear-cut in the whole scale ${ }^{8}$ - a concept that results from the extensive epeirogenic movement that occupied the latest stages of the Cretaceous and the earliest of the Tertiary. Widely over the earth the sea began to retreat from dominant-basins of Cretaceous deposition in Maestrichtian time (late Pierre and Fox Hills of the United States), not to return generally until well after the beginning of the Tertiary. This gave rise, in nonorogenic areas all over the world, to stratigraphic contacts at which typical Cretaceous fossils are pitted contrastively against typical Eocene, a phenomenon of omission that permitted the initial concept of sharp boundary between the eras. Possibly the culmination or maximum of this widespread marine retrogression might serve as a logical boundary, if it could be located and accurately correlated across the earth, but here again there is uncertainty that bars further consideration. The only known place in the world where it seems

${ }^{98}$ Scott, W. B., A history of land mammals in the Western Hemisphere, p. 108, 1913; idem, 2d ed., pp. 224-226, 1937.

Matthew, W. D., Fossil vertebrates and the Cretaceous-Tertiary problem : Am. Jour. Sci., vol. 2 , pp. 209-277, 1921 .

1 Stille, Hans, op. eit., p. 152 .

2 Reeside, J. B., Jr., Stratigraphic nomenclature in the United States: 16th Internat. Geol. Cong. Guidebook 29, pl. 8, 1932.

${ }^{3}$ Ferguson, H. G., and Muller, S. W., Early Jurassic orogeny in west ${ }_{4}$ Stille, Hans, op. cit., pp. $133-138$.
.

${ }^{5}$ Borissjak, A., ய̈ber die Tektonik des Donez-Höhenzuges in seinen nordwestlichen Áusläufern : Centralbl. Mineralogie, 1903, p. 645.

6 Pia, J., Grundbegriffe der Stratigraphie, p. 78, 1930.

Stille, Hans, op. cit., p. 16. 
possible to recognize clearly a horizon of maximum retrogression is in Belgium, and even there it would be difficult to be sure of a valid maximum. According to Bubnoff's summary, the passage from the Danian to the Montian seems to mark the greatest withdrawal of the sea, ${ }^{9}$ but the Montian transgression was very slight and was followed by a withdrawal. The last marine beds in the western interior of the United States, the Cannonball marine member of the Lance formation, appear to mark the end of the late Cretaceous retrogression there, but evidence of the turning point, the beginning of the marine invasion, is lacking; marine successions elsewhere in North America lack an equivalent of the Cannonball, and probably also the stage immediately following. It would be difficult to establish a basis for subdivision on purely epeirogenetic grounds, although it must be recognized that if a purely physical basis is to be sought, one founded on the widespread swings of epeirogenic movement would seem most logical.

\section{THE PALEONTOLOGIC RECORD}

The various values of fossils as markers of geologic time have been widely discussed in recent years, in special treatises as well as in papers devoted to individual cases of correlation and subdivision, ${ }^{10}$ more largely by European authors than American. Perhaps the most thoroughgoing attempt to bring together the really fundamental concepts is that of Bubnoff. ${ }^{11}$ Out of the entire discussion, necessarily complicated because of the large number of variable factors and the uncertainty that still invests many fundamental assumptions, there seem to emerge two general principles. First, there is nothing inherent in fossil occurrences that will serve without question as indicative of contemporaneity. Second, when all possible conditions of occurrence and interpretation are evaluated and a balance of probabilities is struck, fossils afford the surest means yet available for correlation.

But, as pointed out in a foregoing paragraph, correlation is not exactly the same as subdivision, and the problem here considered is one of subdivision. The fact that a given criterion, either paleontologic or physical, affords adequate means of correlation does not necessarily ensure that it will serve as valid basis for subdivision. For example, if major orogenic movements should be demonstrated to be simultaneous across the earth and hence usable for accurate correlation, they might still fail to set the column off into rational divisions. In fact, the evidence reviewed in this paper suggests that with respect to other physical aspects of the record, such as the stratigraphic, and especially with respect to the fossil record, the orogenies would probably make a poor basis. At least they would have to be independent; and they are not sufficiently widespread to serve alone. Conceivably also certain groups of fossils, as for example the ammonites, superior for correlation, might not stand alone as adequate basis for major subdivision.

There is involved in this, evidently, an unstated assumption as to the end to be gained in subdivision. The major units in the scale have been handed down through generations of workers, and the basis on which they rest has been more or less axiomatically accepted from one generation to another as a combination of physical and organic characteristics expressive of that homogeneity and distinctness generally associated with time divisions in any order of magnitude. In this the concepts of unity and distinctness are the essential elements, and if no specification is laid down as to whether the characteristics shall be organic, or physical, or both, they seem to embody a sound general basis for approach to the whole question of subdivision. The two concepts, of unity on the one hand and of distinctness on the other, give rise to two orders of problem-the determination of major unifying features, and the selection of those features that will best serve, in the interest of distinctness, to define exact boundaries. Solution of the second order of problem, the major concern here, should naturally be founded on the characteristics of the first. Regardless of which elements in the total field of possible criteria afford the best means of correlation, the basis chosen for the drawing of a boundary should conform as well as possible to the natural scheme on which the entire division is set up.

Inasmuch as fossils seem to afford the best means of correlation, and in view of the obvious discrepancy between the fossil record and the order of physical events (barring perhaps the epeirogenic), it would seem best, if feasible, to make the division on the basis of some characteristic of the fossils that affords a logical turning point.

In fact, if the question is raised as to what the terms Cretaceous and Tertiary actually mean, one does not go far into the available facts before it is evident that they have come to stand essentially for times in the geologic past when more or less characteristic organisms lived. On this basis a logical boundary would naturally come at the horizon of greatest change between the types, and this principle has been most widely adopted by students of the problem. It is necessary to decide, however, whether the discernment of greatest change shall be attempted for the entire assemblage of known organisms, as a sort of average, or for a single group selected because of outstanding distinctiveness or inherent value in correlation. Both principles have been applied in the discussion of boundary problems. It is not uncommon for the greatest changes in different groups of organisms to come at different horizons, as has been pointed out by Schindewolf ${ }^{12}$ for the passage from Devonian to Carboniferous. In such cases, if summation or averaging is difficult, the tendency naturally is to select a most significant group, as Schindewolf has done in the case cited. In the Cretaceous-Tertiary transition the outstanding changes in fossil succession seem in part to follow this rule. Of characteristic Cretaceous forms the ammonites disappear first, at the top of the Fox Hills, equivalent to the close of the Maestrichtian, and the genus Inoceramus does not occur in the Danian; the dinosaurs disappear at the top of the Lance, equivalent to the close of the Danian. The freshwater mollusks have been considered to undergo no striking change in the zones under question, but these fossils need revision in this part of the stratigraphic sequence, as previously emphasized, and they cannot be seriously considered in their present status. The flora has been widely held to change to Tertiary type with the passage from Fox

\footnotetext{
${ }^{9}$ Bubnoff, S., Geologie von Europa, vol. 2, pt. 2, pp. 1007, 1017-1018, 1935

${ }_{10}$ Pia, Julius, Grundbegriffe der Stratigraphie, pt. A (especially pp. 68-85), 1930 (contains good bibliography). Schindewolf, O., Probleme
der Devon-Karbon Grenze: 16 th Internat. Geol. Cong. Rept., vol. 1 , pp. 505-513, 1936.

${ }_{11}$ Bubnoff, S.. Grundprobleme der Geologie, pp. 120-136, Berlin, 1931 ${ }^{12}$ Schindewolf, O., Die Liegendgrenze des Karbons im Lichte biostratigraphischer Kritik: Cong. Strat. Carb., Heerlen, Compte Rendu, pp. 651-659, Liege, 1928
} 
Hills to Lance and to continue unchanged in dominant aspect through the Lance and Fort Union, but recent paleobotanical study of the transition beds by Dorf ${ }^{13}$ and Brown ${ }^{14}$ has shown the older views on this traditionally moot subject to be erroneous. The floras of the Lance and the Fort Union are evidently distinct. The mammals appear to change most sharply at the passage from Lance to Fort Union, although Matthew, ${ }^{15}$ at least, has argued that the Fort Union mammals should be regarded as Cretaceous in type. This conclusion, it must be observed, finds no evident support among vertebrate paleontologists of the present day.

As a result of these and other more detailed differences in change from Cretaceous to Tertiary types of fossil assemblage, at least three horizons have been proposed to mark the boundary, namely, the Fox HillsLance contact (Maestrichtian-Danian boundary in the European time scale), the Lance-Fort Union (DanianMontian boundary), and the Fort Union-Wasatch (Thanetian-Sparnacian boundary).

The attempt to place a division in this column on the basis of a single group of organisms does not yield satisfactory results. Schindewolf's case for the cephalopods in the Devonian-Carboniferous question seems to be much clearer than any apparent possibility in the Cretaceous-Tertiary problem. Schindewolf ${ }^{16}$ maintains that major subdivisions should be drawn on the basis of the group of organisms used to establish the subsidiary stages. In the western American Upper Cretaceous the fossils most widely effective as zone markers, if a single group is to be selected, are the ammonites and, especially, the scaphites. The ammonites did undergo an important change in the stratigraphic interval under question; they became extinct, and this important event might perhaps be argued as a basis for drawing the line. The disappearance of a group of organisms, however, is in itself a poor criterion for either correlation or subdivision. Even if it were accepted as a valid criterion in the present case, the boundary would fall at the top of the Fox Hills, placing the Lance, with its manifold Cretaceous affinities, in the Tertiary. Of course, in the strict application of Schindewolf's principle this would make no difference, but to the writer it seems that the uncertainty investing the disappearance of a group of fossils in a given stratigraphic section, considering the highly varied possibilities of accident involved, militates against the principle as a unique means of solving boundary problems. For the placement of a boundary in a given section it might be adequate, but for correlation of the horizon thus established with distant sections it is inferior to more inclusive methods.

If no single fossil group will serve, the only apparent alternative is to find the horizon at which the change in total aspect of the fossil assemblage is greatest, and thus to preserve, as well as may be, the concept of distinction between typical Cretaceous and typical Tertiary. This may rule out some groups of organisms as a residual minority, for example, the flora, if the older views respecting paleobotanic affinities are in any measure correct; but it involves the only type of method in which the paleontologist finds strength in dealing with his complex material, namely, the essentially statistical. Summation of all available evidence, with the checks and balances inherent in logical evaluation of the units gathered into the summary, seems a much stronger procedure in general than pinning all faith on one ele- ment. If paleontologists disagree too variously as to the significance of different groups of fossils, the problem becomes admittedly difficult, but in the present case there seems to be agreement as to the major part of the evidence. The greatest change in total fossil assemblage takes place at the boundary between the Lance and the Fort Union formations. At this horizon the dinosaurs disappear, and the placental mammals appear. The Cannonball marine fauna, which occurs immediately beneath it, has been shown by Stanton ${ }^{17}$ to be dominantly Cretaceous in aspect, although it contains a number of species of Tertiary affinity that emphasize its position near a logical boundary. The changes that occur between the Danian and the Montian of Europe are similar, and European geologists have been drawing the boundary at this horizon for some time. Despite a measure of uncertainty in the correlation between America and Europe, the apparent agreement in circumstance lends strength to the principle as applied to the American section.

Of the two groups on which difference of opinion has most strongly centered, the flora and the mammals, it may clearly be said that present-day judgment affords support rather than rejection of the Lance-Fort Union boundary. The flora, as noted above, may not conflict so strongly with the other evidence as was thought by earlier workers, and even if it does, the phenomenon will be entirely expectable; the great changes in the plant world have occurred, in general, at times different from those in the animal world. Further, the floral evidence is logically subordinate to the faunal, in that the entire scheme of geologic subdivision is fundamentally paleozoologic; a column based on paleobotany alone would have strongly different outlines. As to the mammals, modern students agree that the greatest change comes at the Lance-Fort Union boundary; the Lance mammals are definitely of Mesozoic type, the Fort Union of Cenozoic. ${ }^{18}$

It may be objected, as suggested above, that of the various features of fossil occurrence usable in correlation the ones here stressed, namely, the disappearance of the dinosaurs and the appearance of the placental mammals, are among the weakest. Either the first or the last appearance of a fossil group is likely to represent accident of preservation, of sedimentation, or of migration, and in any case if the phenomenon is sharply defined it probably reflects a gap in some phase of the record. Under the concept of evolution the sudden first appearance of a fossil assemblage in any section implies a lack of knowledge respecting its forerunners, which is hardly a valid basis for either correlation or subdivision: this matter has been ably stated by Renier. ${ }^{19}$ Likewise, the disappearance of a group at any one place bears no inherently cogent time relation to the disappearance at another place. The two events here concerned, however, are juxtaposed in the record at widely separated localities, and with the last marine fauna of Cretaceous aspect. Their inherent weakness is offset,

\footnotetext{
${ }^{13}$ Dorf, Erling, Relationship between floras of type Lance and Fort Union formations: Geol. Soc. America Bull., vol. 51, pp. 213-236, 1940. ${ }^{14}$ Brown, R. W.. oral communication.

15 Matthew, W. D., op. cit.

${ }^{16}$ Schindewolf, O., op, cit., p. 655 .

${ }_{17}$ Stanton, T. W., and Vaughan, T. W.. The fauna of the Cannonball marine member of the Lance formation: U. S. Geol. Survey Prof. Paper

128. pp. 1-60. 1920.
18 Simpson, G. G., Third contribution to the Fort Union fauna at Bear Creek, Mont,; Am. Mus. Novitates 345 (especially table at end), 1929 Glossary and correlation charts of North American Tertiary mammal bearing formations : Am. Mus. Nat. Hist. Bull. 67, art. 3, pp. 83-84, 1933 . ${ }_{19}$ Renier, A., discussion, in Jongmans, Cong. Strat. Carb., Heerlen, Compte Rendu, p. xxxiv, Liege, 1928.
} 
to some extent at least, by this concurrence, and the probability that they give specious appearance of contemporaneity is greatly lessened.

It is interesting to observe that $\mathrm{Pia}{ }^{20}$ rejects the conclusion of Pfeffer ${ }^{21}$ that the Cretaceous-Tertiary boundary be defined by the extinction of the dinosaurs and the appearance of the placental mammals, on the grounds that a division must not be made in continental beds alone, but only in reference to a typical marine section. This argument fails to take account of the possibility, eminent in the present problem, that the time of greatest change, the logical level for a boundary, is not represented anywhere in the world by accessible beds other than those of continental origin. The North American section probably contains a good deal in the Cretaceous-Tertiary transition that is not represented by accessible marine beds anywhere. If a boundary based on acceptable criteria happens to fall in such a section, it should be placed there. There is nothing intrinsically transcendental about the marine section to demand that important boundaries be restricted to it. The tendency to regard marine beds as the only possible standard, to the exclusion of potential values in many excellent continental successions, may perhaps be carried too far. Correlation with marine sections, if such exist, is of course important, but to force a boundary into the marine section merely on the assumption of superiority in general criteria is hardly reasonable.

It must be -recognized that Pia's stricture on the placement of boundaries in continental sections is based on a fundamental philosophy somewhat different from the concepts so far considered here. In a later paper ${ }^{22}$ than the one above cited Pia has expounded more fully his views on the general subject of geologic chronology, and in particular has clarified his stand as to the commanding qualifications of the marine section for the establishment of boundaries. His entire argument, set forth in the form of six theses, is too extensive to review here, but his most important postulates bear directly on the subject at hand and may not be passed without comment. To Pia all geologic time units are purely artificial; no attempt to set up "natural" divisions should be made. The time scale should be regarded primarily as a device of convenience. Restriction of standard divisions to the marine section is an element in the quest for convenience; marine horizons are easier to recognize over wide areas.

With most of Pia's argument the writer agrees, but the prescription that all boundaries must be purely artificial seems to venture farther than necessary from the field of available knowledge. If a more or less natural basis for a given division can be found, it is surely superior to an artificial one, or in any event one that rests on no better qualification than the mere possibility that geologists in general might be brought to accept it. As to the case in hand, there is, after all, typical Cretaceous, and there is typical Tertiary; the two are quite different. If between the two a horizon can be found that marks off something significant of the difference and at the same time meets other reasonable requirements, it ought to be more effective than one based merely on convenience and agreement.

As far as convenience and efficiency are concerned, there are considerations that argue superiority of the continental sections here involved over any known alternative marine sections. In the first place, as to the available paleontologic evidence, it is a fact of signal importance that the vertebrates have evolved more rapidly than the invertebrates, and where abundant are more delicate time markers, despite the greater difficulty, compared with the invertebrates, of allowing for migration and contemporaneous occurrence of different facies. The importance of the vertebrates throughout the column from the Upper Cretaceous on is too well known to require further comment on this point. Second, full application of Pia's principles to the problem of the Cretaceous-Tertiary boundary would result in a decision rather more divergent from established usage than would seem wise or practical. As a result of the protracted withdrawal of the sea during late Cretaceous and early Tertiary times, a marine horizon adequately distributed and recognizable to meet the stipulates of convenience would fall well within divisions long accepted without question as either Cretaceous or Tertiary - in other words, the proposal of such a division would be revolutionary to an extent neither necessary nor practical. Further, the boundary here recommended possesses one very important attribute of convenience, namely simplicity of application in most parts of the world. Inasmuch as marine units that contain the boundary are lacking in so many of the great areas of Cretaceous and Tertiary sedimentation, the problem of drawing a line between the two is greatly simplified for much, if not most, of the world.

In final point, however, it must be observed that the very possibility of recognizing a line of greatest total change in the life succession suggests weakness in the division thus made. Under supposedly normal conditions of evolution such a punctuation must mean accident resulting in omission that could only fortuitously be simultaneous over the world. If the theory of evolution postulating "critical periods" be accepted, explanation may be found in the quickened evolution of some groups, such as the mammals, and the concurrent devastation in others, such as the dinosaurs, that invested the close of the Mesozoic. But this theory is by no means demonstrated. Berry ${ }^{23}$ has pointed out certain of its weaknesses, as well as other misconceptions widely cherished in related fields. If the record is scanned without prejudice, as Berry recommends, as many important changes in the living world are seen to have occurred within the accepted divisions of the time scale as near the boundaries. Furthermore, the important changes that do appear in the boundary zones may be more apparent than real; to take as an example one of the changes important in the present question, the sudden appearance of the placental mammals does not certainly mean a sudden surge in mammalian evolution. At any place in the world where the Mesozoic mammals are followed immediately by the early Cenozoic, the placentals of the Cenozoic assemblage are newcomers, not related to the underlying Mesozoic marsupials; they are descendants of stocks for which we have no record and which might just as well have undergone somewhere a long preliminary evolution as a sudden upsurge. The absence of known ancestral stock for so many important animal groups that appear suddenly, well developed, in the fossil succession should be more convincing than it seems to be of the incompleteness of the geologic record,

\footnotetext{
${ }^{20} \mathrm{Pia}$, Julius, Grundbegriffe der Stratigraphie, pt. A, p. 84, 1930. ${ }_{21}$ Pfeffer, G., Die Frage der Grenzbestimmung zwischen Kreide und Tertiär in zoogeographischer Betrachtung, Jena, 1927 (not seen). ${ }_{22}$ Pia, J., Das Wesen der geologischen Chronologie: Cong. Strat. Carb., Heerlen, 1935, vol. 2, pp. 857-902, 1937.

${ }_{23}$ Berry, E. W. Shall we return to cataclysmal geology ?: Am. Jour. Sci., vol. 17, pp. 1-12, 1929.
} 
and in recognition of this incompleteness it is impossible to sustain in theory any significant variation in the rate of evolution. The boundary between Cretaceous and Tertiary placed on the basis of any sort of pronounced change in the fossil succession cannot escape real possibility of fallacy, and it might perhaps best be regarded frankly as an arbitrary device, founded as far as possible on phenomena of natural significance but hardly expressive of any comprehensive principle.

\section{NATURE AND EXTENT OF OROGENIC MOVEMENTS}

\section{NOMENCLATURE}

During the part of geologic time covered by this paper at least three orogenic movements took place. The term orogenic movement is here used in the sense discussed by Stille ${ }^{24}$ to mean compressive disturbance productive of folded and thrust structures. The first of the three movements definitely recognized in central Utah occurred between the late Jurassic and the early Upper Cretaceous, the second, between middle and late Montana times, and the third probably not long after the beginning of the Tertiary. Later disturbances, both orogenic and epeirogenic, affected the area, but they are outside the scope of this paper. The second and third movements here described are definitely proved and fixed within narrow stratigraphic limits by angular unconformities; the first is not so demonstrated, but is almost certain to have occurred, as pointed out below. The first two movements were profound and probably widespread, whereas the third was confined in central Utah to a fairly narrow belt.

The nomenclature of these orogenies merits some explanatory mention. In referring to the various episodes of the orogenic succession North American geologists have generally followed the scheme of nomenclature brought together by Blackwelder. ${ }^{25}$ More recently Stille ${ }^{26}$ has proposed a world-wide scale which, by virtue of its greater areal scope and the increased volume of fact on which it is based, is much more elaborate. Stille's scheme is founded on the postulate of orogenic simultaneity discussed in the foregoing part of this report, and as to detail the validity of his groupings may per-haps be questioned. Further, the lack of agreement between recently discovered North American orogenies and the ones specified by Stille makes it impossible to adopt his nomenclature without somewhat problematic alteration. Blackwelder's list was formulated before the actual intricacy of orogenic succession in the Mesozoic and Cenozoic was known, and it presents a much more discrete picture than is now possible. The increasing number of orogenic pulses recognized in the North American Cordillera, not to consider the world as a whole, raises the question whether valid grouping is possible. There also appears the corollary question whether anything more comprehensive than local nomenclature is justified.

It is not proposed here to offer any general solution of these difficulties. However, it does seem possible to recognize a group of disturbances in late Cretaceous and early Tertiary times to which the long-established term Laramide may apply. Where the limits of this group should be drawn is not easy to specify. As originally applied, the term "Laramide" was meant to designate a single great disturbance separating the Cretaceous from the Tertiary. The structures attributed to this disturbance are now seen to have resulted from a suc- cession of movements beginning not later than the early Upper Cretaceous and continuing through the Tertiary to the verge of the Quaternary; perhaps even later. To call this whole succession Laramide would destroy the distinctive significance of the name and would gain none of the ends normally to be sought in nomenclature. It would seem more appropriate to restrict the term "Laramide" to the group of movements that occurred in the later part of the Upper Cretaceous and the early part of the Tertiary, certainly not going beyond Eocene time. For North America such reasonable limits now seem possible, but when the world-wide scale is contemplated, clarity of distinction disappears. Movements now known in central Utah occupy gaps in Stille's scale and produce a fairly even spacing of orogenic pulses; the second of the three here described falls about midway between the late Subhercynian and the early Laramide of Stille's classification. It seems nevertheless worth while to retain the name "Laramide" in the sense above suggested, at least until more comprehensive knowledge shall require some other procedure.

If the name "Laramide" is retained, however, the equally long-established word "revolution" should be abandoned. It is not only inaccurate as a specific substantive but also misleading in its implication of general cataclysm that almost certainly never happened. The evidence for central Utah alone suffices to show that high mountains have been formed without the sweeping changes, either geographic or biologic, that were formerly visualized as basis for use of the term "revolution."

For the purposes of this discussion, then, the first orogeny in central Utah will be called the mid-Cretaceous, the second, the early Laramide, and the third pre-Flagstaff. The first is not yet correlated accurately enough with any of the widely recognized orogenic epochs of western North America to justify a special name. The second, in terms of the foregoing discussion, may properly be called Laramide. In distinction from the strong Laramide movements that occurred later in the Rocky Mountains farther north, this disturbance is designated early Laramide; it is probably the earliest that could reasonably be assigned to the group. The third movement is not yet well enough correlated with outlying regions to justify other than a local name; although it clearly came within the limits of the Laramide group of movements, it is here simply referred to the local stratigraphic column.

\section{SCOPE OF DISCUSSION}

The following part of this report is devoted to general description of the three orogenic movements, the evidence by which they are recognized, and their probable extent as apparent from comparison with other regions. In the comparisons here made, evidence considered for other regions is restricted for the most part to angular unconformity between strata of known age, or other strong proof of orogenic dates in the folded belts themselves. No attempt is made to analyze the evidence in the undisturbed intermontane and plains districts, where disconformities in considerable variety are difficult to interpret, and, in present state of knowledge, too uncertain in significance to bear serious con-

\footnotetext{
${ }^{24}$ Stille, Hans, Present tectonic state of the earth : Am. Assoc. Petroleum Geologists Bull., vol. 20, pp. 850-851, 1936.

${ }^{25}$ Blackwelder, Eliot, The orogenic epochs of North America : Jour. Geology, vol. 22, p. $645,1914$.
} 
sideration. Whereas disconformity of the type recognized in the nonfolded belts might signify orogeny, it might just as well record nothing more profound than a slight general uplift or simply a climatic change. On the other hand, a profound orogenic movement might leave no observable trace in sedimentary successions not far from the scene of strong folding; the early Laramide movement of central Utah produced no disconformity detectable by ordinary observation in the perfectly exposed sections of the Book Cliffs, and the preFlagstaff movement left no visible trace in sections only a few miles east of the folded belt. Data at present available on the disconformities in the late Cretaceousearly Tertiary succession are insufficient, in most cases, to allow discrimination.

\section{MID-CRETACEOUS OROGENY}

In recent years geologists working in the eastern and southern parts of the Great Basin have been assigning the main folding and thrusting to the Laramide epoch, ${ }^{27}$ in change from the earlier concept that all Great Basin folding was late Jurassic, or Nevadian. These assignments are all based on comparison with the folded belts to the east where Laramide folding dominates; sediments of the ages necessary to fix the times of folding in these ranges are generally lacking. The evidence now available for central Utah suggests that this region was penetrated by folding earlier than Laramide; and there are facts for other areas that either point definitely toward the same conclusion or may be so interpreted.

The rocks of the Indianola group in central Utah contain conglomerates, especially in the lower and upper parts, which are so coarse and contain so much Paleozoic limestone debris that a highland source nearby to the west is certain. The conglomerates are coarsest toward the west in the Gunnison Plateau and the Cedar Hills. ${ }^{28}$ They become finer eastward, very rapidly in the Wasatch Plateau, on the east front of which they are represented by the Mancos shale. Furthermore, they are very thick in the western belt; Schoff reports nearly 15,000 feet for the Indianola group in the Cedar Hills, and in the Gunnison Plateau east of Levan the Indianola group is probably not less than 10,000 feet thick, with conglomerate scattered throughout but concentrated largely in the basal and upper parts. In the Gunnison Plateau (fig. 16), beds of the Indianola group rest without apparent angular discordance on the Arapien shale and it seems unlikely that the disturbance leading to the formation of the conglomerates was stongly effective on the site of the present Wasatch Mountains. That there was a compressive disturbance seems almost certain, especially when the Indianola conglomerates are compared with those of the Price River formation in the Thistle district, which overlap and abut on the truncated early Laramide folds in the steep front of the late Cretaceous mountains. The Price River and Indianola conglomerates are much alike; the source of the Price River boulder fans is evident, and it is not likely that the source of the Indianola materials was much different. In any event it is difficult to picture, without folding or thrusting, a sharply bounded upheaval such as that necessary to produce the highland mass from which the Indianola was derived. The writer therefore postulates a belt of strong folding not far west of the southern Wasatch Mountains.

The possibility should also be considered that this earlier folding did penetrate the southern Wasatch Mountains. The only place so far seen in the western belt where the Indianola-Arapien contact clearly appears to lack angular discordance is the locality in the Gunnison Plateau mentioned above, and there the Laramide and later deformations were not strong. The relations in the base of Mount Nebo are obscure, and in the Indianola district they are difficult to interpret, although they easily permit the assumption of parallelism. In Salina Canyon, which is near the eastern limit of the Laramide folding, the contact is almost certainly conformable. Elsewhere the rocks have been too strongly deformed to permit certain conclusion. It is evident only that in the area as a whole there is no extensive angular discordance beneath the Indianola. However, some effects of pre-Indianola folding as far east as the southern Wasatch Mountains are possible, even if not pronounced.

The age of this orogeny lies somewhere between the late Jurassic and the early Upper Cretaceous. The marine beds in the Indianola are above the basal conglomerates of the group, and it is impossible to assign a precise date. However, the whole mass of strata in the lower Indianola is definitely a unit, to all evident effect a consecutive response to the uplift, and it seems most likely that the disturbance occurred at some time near the beginning of the Upper Cretaceous.

As to the possible extent of this movement, facts are available that suggest a rather long stretch on the eastern border of the Great Basin and to the north. Beginning in southern Nevada the Overton fanglomerate, originally classified as Miocene (?), ${ }^{29}$ has recently been found to contain species of Tempskya and Microtaenia, fossil ferns that are known elsewhere in beds of early Upper Cretaceous age only. ${ }^{30}$ The Overton is the oldest postorogenic sedimentary deposit in the Muddy Mountains, ${ }^{31}$ where it lies in angular unconformity on folded and thrust Mesozoic rocks, the youngest of which are Jurassic in age; the folding, apparently limited in age between the Jurassic and the Miocene, was assigned by Longwell to the Laramide epoch. If the basal Overton is early Upper Cretaceous, however, this orogeny could not have been Laramide, and it may well have been the same as the pre-Indianola of central Utah.

Passing on to the north, in the central Wasatch Mountains the major deformation has been placed, in all recent geologic study known to the writer, ${ }^{32}$ in the Laramide epoch, the late Cretaceous, or the early Tertiary. 'The geologists of the Fortieth Parallel Survey, however, described conglomerates and sandstones of Upper Cretaceous age assigned to the Dakota and Colorado groups, in angular unconformity over strongly folded Carboniferous and early Mesozoic rocks, in two localities, east of Salt Lake City and near Weber River on Lost Creek. ${ }^{33}$ Because at many other localities the Cretaceous is apparently conformable on the Jurassic, and because in the district east of Salt Lake City the

\footnotetext{
${ }^{27}$ Nolan, T. B., The Gold Hill mining district, Utah: U. S. Geol. Survey Prof. Paper 177, pp. 63-64, 1935. Gilluly, James, Geology and ore deposits of the Stockton and Fairfield quadrangles, Utah: U. S. Geol. Survey Prof. Paper 173, p. 73, 1932. Longwell, C. R., Geology 123 1928 . Hewett I. Ge 123, 1928. Hewet, S. Greosy an Pre papt 28 Sangle, Nev.: . S. Geol. Surfer 20 Schoff, S. L., Geology of the Cedar Hils,

Geol. Survey Bull. 798, pp. 89-90, 1928. Boulder Dam: U. S. Geol. Survey Bull. 871, pp. 121-122, 1936.

31 Longwell, C. R., op. cit., pp. 68-74.
32 For summary and bibliography see Beeson, J. J., Mining districts and their relations to structural geology: Am. Inst. Min. Met. Eng.

Trans., vol. 75, pp. 768-792, 1927. ${ }_{33}$ King, Clarence, U. S. Geol. Expl. 40th Par. Rept., vol. 1, p. 304, 1878. Emmons, S. F., The Wasatch Range, U. S. Geol. Expl. 40 th Par. Rept., vol. 2 , pp. $381-383,391,1877$.
} 
relations are somewhat obscure, King and Emmons offered their account with strong reservations. Their findings, however, are evidently valid. Mathews corroborated them in 1931 , but his account contains no suggestion of the importance of the phenomenon in the regional geologic history. ${ }^{34}$ Other geologists appear to have overlooked the older reports, possibly excepting Beeson, ${ }^{35}$ who, in a tabular summary of geologic history, indicated mild compression between Jurassic and Cretaceous, but did not discuss the matter. Eardley ${ }^{36}$ specified in a tabular outline of geologic history for the southern Wasatch Mountains "crustal disturbance * * * probably beginning of Laramide Revolution" at the beginning of Colorado time, but did not discuss the point and gave neither evidence nor citation of authority. Thus, the possibility of important folding in the central Wasatch Mountains at some time between the late Jurassic and the early Upper Cretaceous has been overlooked or slighted by most students of the region; the evidence here reviewed makes such folding appear highly probable.

The foregoing should not be interpreted to mean that the central Wasatch Mountains underwent no Laramide deformation. In all parts of the range where Cretaceous rocks of Colorado age are present they are deformed, and in the southern part the Laramide movement was obviously the strong one. In the central and northern districts, however, the older movement may have been equally strong or stronger; the Cretaceous (?) rocks of the Salt Lake-Lost Creek district are by no means so profoundly deformed as were the Jurassic and older rocks before them.

It might be noted, as regards the date of this orogeny in the central Wasatch Mountains, that in the Coalville district the conglomerates of Colorado age ${ }^{37}$ lie in the middle part of the stratigraphic interval characterized by the Carlile fauna, ${ }^{38}$ equivalent to the upper part of the Benton in the standard section of the Great Plains. To interpret this occurrence in the present state of knowledge is admittedly somewhat precarious. It does suggest, however, the culmination of an orogenic pulse in early Colorado time.

Still farther north, in the mountains of southern Idaho, the earliest folding came before the deposition of the Wayan formation, described by Mansfield ${ }^{39}$ as nearly 12,000 feet thick and assigned by him with doubt to the Lower Cretaceous. The Wayan formation is now assigned to the Upper Cretaceous ${ }^{40}$ it contains Tempskya, among other things, and is at least in part equivalent to the Bear River formation of southwestern Wyoming. As described, the Wayan lithology strongly suggests Indianola, and the new age assignment adds to the probability that the two are at least partly equivalent. In Mansfield's sections the Wayan is shown in angular unconformity over older folded rocks. This movement demonstrated for southeastern Idaho may have been the same as the pre-Indianola of central Utah.

It should be noted, in connection with these occurrences, that the determination of Laramide folding for the Tintic Mountains ${ }^{41}$ and the Canyon Range, ${ }^{42}$ near the eastern margin of the Great Basin, rests on the identification of post-orogenic conglomerates in these areas as Wasatch in age. These conglomerates are similar in all respects to the Indianola and Price River conglomerates of the Wasatch Plateau, which were originally identified as Wasatch, and they may well be in part of early Upper Cretaceous age. The same is true of the great masses of conglomerate in the Pavant
Mountains ${ }^{43}$ and elsewhere in the general region. $\mathbf{R e}-$ connaissance examination of these occurrences has impressed the writer strongly with the possibility that these conglomerates include Indianola and perhaps also Price River strata.

These facts suggest that in the broadly arcuate belt between southern Nevada and southeastern Idaho, whose eastern margin is shown on figure 20 , there was

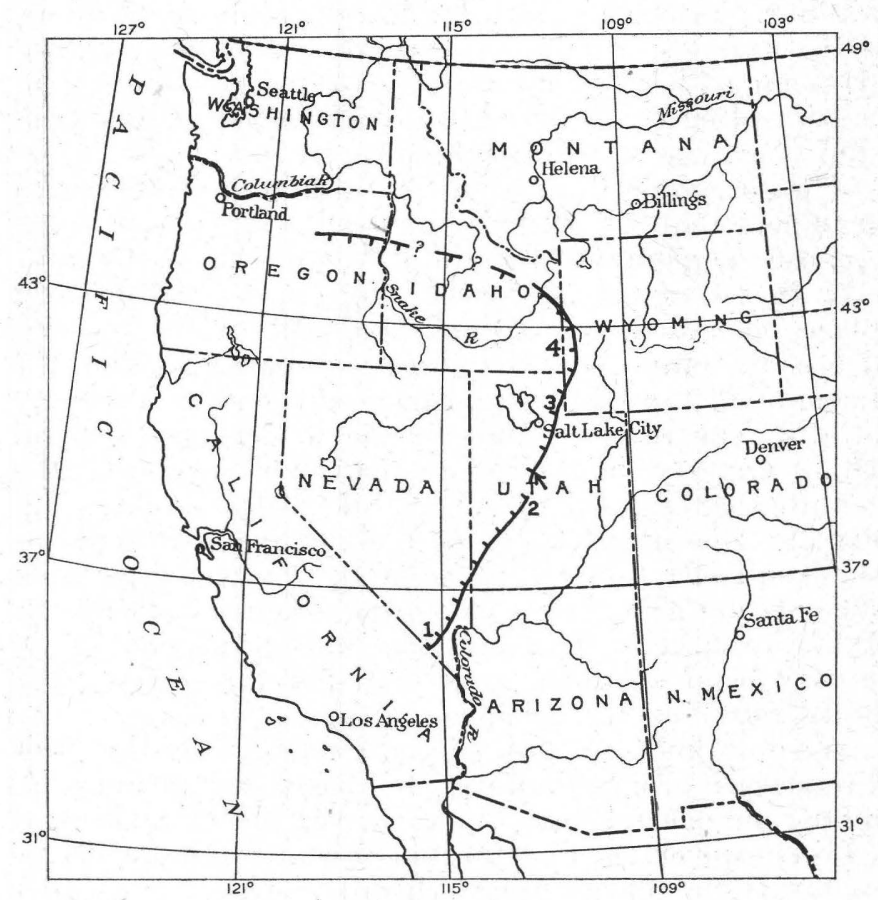

Figure 20.-Map of western part of United States showing probable eastern margin of mid-Cretaceous folding. 1, Muddy Mountains ; 2, areas west of Wasatch Plateau ; 3, central Wasatch Mountains ; 4, ranges of southwestern Idaho.

strong orogeny at some time near the beginning of the Upper Cretaceous. Farther north in the Rocky Mountains there is no evidence of such movement, and in western Montana there is positive proof of its absence; Calkins and Emmons ${ }^{44}$ have described black marine shale of Colorado age overlying the Kootenai formation with no sign of angular discordance, in the Phillipsburg district, Montana, well behind the front range in the heart of the Rockies. The folding either died out north of southern Idaho or veered northwestward. The strong northwest trend of the folds in the northern part of the area described by Mansfield ${ }^{45}$ suggests the latter

\footnotetext{
${ }^{34}$ Mathews, A. A. L., Mesozoic stratigraphy of the central Wasatch
Mountains; Oberlin College Lab. Bull., new ser., vol. 1, pp. 48-50, 1931.

${ }_{36}^{35}$ Beeson, J. J., op. cit., p. 765 . Mountains : Mich. Acad. Sci. Papers, vol. 19, p. 398, 1934.

${ }_{37}$ Wegemann, C. H., The Coalville coal field, Utah: U. S. Geol. Survey

Bull. 581, p. 112, 1915. western part of the San Juan Basin, Colo. and N. Mex.: U. S. Geol Survey Prof. Paper 134, p. 10, pl. 3, 1924: In Gregory, H. E., and
Moore, R. C., The Kaiparowits region: U. S. Geol. Survey Prof. Paper 164 , p. 113, 1931.

${ }^{39}$ Mansfield, G. R., Geography, geology, and mineral resources of part of southeastern Idaho: U. S. Geol. Survey Prof. Paper 152, pp. 105-108, 195 , pls. $5,11.1927$

. R. American Cretaceous ferns of the genus Tempskya: U. S. Geol. Survey Prof. Paper 186-F, 1937.

ti Lindgren, Waldemar, and Loughlin, G. F., Geology and ore deposits of the Tintic mining district, Utah : U. S. Geol. Survey Prof. Paper 107, pp. 103-104, 1919 . Utah: U. S. Geol. Survey Prof. Paper 90, pp. 53-58, 1914.

${ }_{43}$ Richardson, G. B., Underground water in Sanpete and central Sevier Valleys, Utah : U. S. Geol. Survey Water-Supply Paper 199, p. 10, 1907. Calkins, F. C., and Emmons, W. H., U. S. Geol. Survey Geol. Atlas,

Phillipsburg Folio (No. 196), p. $9,1915$.
${ }^{5}$ Mansfield. G. R., op. cit., p. 131.
} 
alternative; the mountain front of early Upper Cretaceous time probably curved around in a sweeping arc through southeastern and central Idaho into the region now covered by the lavas of the Columbia Plateau. This trend may possibly join the lineaments of east and southeast-trending folds in the Pacific districts, ${ }^{46}$ where some evidence of mid-Cretaceous folding ${ }^{47}$ has been reported, but the dates of the movements are poorly defined in these western mountains, and the transverse folding in the Cascade Mountains seems to be older than Jurassic. Furthermore, there seem to be no known facts on which to premise mid-Cretaceous folding in eastern Oregon, ${ }^{43}$ but for future investigators the possibility may be well worth holding in mind.

The foregoing discussion should not be construed as argument that the orogeny involved comprised a single episode, contemporaneous in all the districts cited, nor even that it was concentrated in one episode at any one place. The orogenic disturbance indicated by the evidence reviewed may have been separated, like the Laramide, into distinct episodes of different intensity at different places. Indeed, the evidence in central Utah strongly suggests more than one movement; the conglomerates in the upper part of the Indianola group may in some respects be most logically interpreted as the result of a distinct orogenic disturbance, later than the one that gave rise to the lower conglomerates of the Indianola. This possibility is important enough to justify brief comment as a final point respecting the mid-Cretaceous disturbance.

As now known, most of the evidence for the midCretaceous orogeny affords no basis for postulating more than one movement at any given place. In central Utah, however, the distribution of coarse conglomerates in the Indianola group is difficult to visualize as anything but the result of two movements separated by a notable interval of quiet. In the Cedar Hills, the Gunnison Plateau, and the western border of the Wasatch Plateau there are conglomerates in the upper part of the Indianola group which in general are just as coarse and prominent as those in the lower part. In the Cedar Hills and the Gunnison Plateau the conglomerates are scattered through the Indianola in a manner that might easily be interpreted as the result of protracted orogeny, perhaps with a culminating surge toward the end. In the section of the Sixmile district, however, the Sixmile Canyon formation contains conglomerates that are separated from those of the Sanpete formation by about 2,500 feet of finer sediments. In this district the Sixmile Canyon conglomerates are more prominent than those of the Sanpete. These upper masses of coarse debris must, like the lower, have been derived from a high land mass not far away, and, if the reasoning applied to the lower conglomerates is consistently followed, the uplift of this land mass is most likely to have involved orogenic disturbance. The finer sediments of the Allen Valley and Funk Valley beds are present at the northern and southern ends of the border belt of the Wasatch Plateau, as well as in the Sixmile district, and they are evidently extensive in this general belt flanking the ancient highlands. They certainly represent a time when little or no coarse debris was being swept into the basin of deposition. In the existing setting, this would normally be interpreted to indicate diastrophic quiescence and the slow wearing down of reduced highlands remaining from the initial mid-Cretaceous disturbance. Other facts for regions to north and south of the Wasatch Plateau, as far away as the Coalville district and the Kolob Plateau, tend to support this general picture.

The mid-Cretaceous orogeny, then, appears to have comprised two separate pulses in central Utah. The evidence for this duality, however, is probably not complete enough to justify a definite commitment, and in summing up the orogenic history of the region it is perhaps wise to designate the second movement as probable but not positively demonstrated.

\section{EARLY LARAMIDE OROGENY}

The early Laramide orogenic episode is recorded in the strongly folded strata of the southern Wasatch Mountains and in the continuation of that folded belt southward through Sanpete and Sevier Valleys, the Gunnison Plateau, and the western border of the Wasatch Plateau. The area affected by this movement doubtless extends far westward into the Great Basin, into territory not yet studied in detail. In the Wasatch range proper the folded rocks rise high above the surrounding territory and form the main mass of the mountains, but in the districts to the south and east they were planed off by erosion immediately after the folding, and they are for the most part buried under postorogenic sediments of the Price River and later formations, in pronounced angular unconformity. The eastern margin of the folded belt follows rather closely the trend of the eastern borders of Sanpete and Sevier Valleys and penetrates into the Wasatch Plateau in the northern part between Thistle and Indianola, and in the southern part between Manti and Salina.

The folding is dated between middle and late Montana times by the angular unconformity and the regional relations of the strata involved; these phenomena are described sufficiently for the purposes of the present report in the foregoing account of the stratigraphy. The angular unconformity is locally very striking in the Thistle-Indianola district. (See pls. $21, B$, and 24, $A$.)

Along the east front of the southern Wasatch Mountains it is also prominent, as described by Eardley, ${ }^{49}$ and in the Cedar Hills it is well developed and widespread, as found by Schoff. ${ }^{50}$ It is also exposed on the east front of the Gunnison Plateau near Wales (pl. 24, $B$ ), and in Sixmile Canyon (pl. 25, A, and fig. 17). At all these places the beds above the nonconformity are either Price River or North Horn. At the Wales and Hjork Creek localities there is evidence of later disturbance, which occurred after the period of time covered by this report. (See pls. 21, B, and 24, B.) East of Indianola and in the Salina Canyon district (pl. $25, B)$ the older folded rocks are overlain by the Flagstaff limestone, and here they were probably affected by the pre-Flagstaff movement, although these occurrences may merely constitute areas that remained high long after the early Laramide movement and were not covered by sediments until Flagstaff time. Where the intervening sediments are not clearly present, it is difficult to recognize the separate effects of successive movements.

${ }^{46}$ Gilluly, James, Reed, J. C., and Park, D. F., Jr. Some mining districts of eastern Oregon: U. S.' Geol. Survey Bull. 846-A, p. 20, 1933. Waters, A. C., Transverse folding, Cascade Range: Geol. Soc. America Proc. 1935, p. 116 (abstract), 1936.

${ }_{47}$ Blackwelder, Eliot, The orogenic epochs of North America: Jour. Geology, vol. 22, pp. 645-646, 1914.

${ }_{48}$ Lupher, R. I.., personal communication.

${ }^{40}$ Eardley, A. J., Structure and physiography of the southern Wasatch Mountains: Michigan Acad. Sci. Papers, vol. 19, p. 398, 1934 : Stratigraphy of the southern Wasatch Mountains: Michigan Acad. Sci.

Papers, vol. 18, p. 334, 1932 . 
As a whole, the evidence from which the early Laramide orogeny has been discerned is very clear, perhaps as clear as such evidence might ever be.

The date now ascertained for the strong Laramide folding in central Utah is the earliest on record for this important series of late Cretaceous and early Tertiary disturbances, and the question naturally arises whether the movement was merely local. The general absence in the Cordilleran region of evidence even suggestive of folding in Montana time would tend to the suspicion that it might have been neither widespread nor important. When carefully reviewed, however, this lack of evidence is seen to be of essentially neutral value, and in none of the known mountain districts do the facts exclude possibility of late Montana folding.

The early Laramide folding has been definitely recognized as far north on the east front of the Wasatch Mountains as the district surrounding Thistle. The extent to which it was effective in the ranges farther north cannot be specified until the ages of the postorogenic conglomerates of that region, hitherto generally designated as Eocene, are certainly known. The thickness and prominence of the conglomerate in the Price River formation in the Thistle district, as well as the intensity of the folding in the rocks beneath it, easily suggest considerable northward extension of the movement. It is likely, considering all the regional evidence, that the postorogenic conglomerates in the central Wasatch Mountains are in part of Price River age, although some, as already pointed out, are almost certainly of Colorado age. In these mountains, between Provo and Weber Rivers, rocks of Upper Cretaceous age are involved in the folding, but the age of the youngest disturbed beds is not known; in the main range of the Wasatch Mountains no rocks of late Montana age have been reported. Farther east, in the Coalville district and other border belts of the Uinta Mountains, the strata of Montana age give no clear evidence of orogeny. If early Laramide disturbance occurred in this latitude, apparently it did not penetrate as far east as the Coalville district. For many miles around Coalville, however, there is a complex of conglomerates, yet largely unstudied, that may contain the equivalent of the Price River formation. This whole area east of the central Wasatch Mountains was affected by disturbances later than the early Laramide, some later than the period of time covered by this report, and careful study will be necessary before the orogenic succession can be laid out with any assurance. To sum up for the central Wasatch Mountains, it seems that the early Laramide orogeny may well have affected the area, although convincing evidence is yet lacking.

Farther north, the Bannock overthrust of southeastern Idaho has been interpreted by Mansfield ${ }^{51}$ to represent the culmination of Laramide movement in that part of the Cordillera. This thrusting occurred at some time between the deposition of the Wayan formation and that of a conglomerate assigned by Mansfield to the Wasatch formation. As pointed out in the discussion of the mid-Cretaceous orogeny, the youngest beds in the Wayan formation are now known to be of Colorado age. The evidence on which the postorogenic conglomerate is placed as Wasatch is similar to that from central Utah on which the conglomerates of the Price River formation in the western Wasatch Plateau were originally identified as Wasatch, and the conglomerate in Idaho may not be Eocene in age. Mansfield ${ }^{52}$ identified it provi- sionally with the Knight or the Almy formation of southwestern Wyoming, ${ }^{53}$ recognizing no distinction between the two in Idaho and expressing doubt that they are separable in the type area. As pointed out on $\mathrm{p}$. 138, the Knight contains the Wasatch fauna, but the Almy is not accurately dated at the type locality; in the light of the writer's field observations it is distinct from the Knight and probably much older. Therefore the age of the folding and thrusting in southeastern Idaho cannot be precisely ascertained. In southwestern Wyoming Veatch ${ }^{54}$ placed the main Laramide disturbance between the Adaville formation, probably of late Montana age ${ }^{55}$ and the Evanston formation, probably of Fort Union age. Schultz ${ }^{56}$ drew the same conclusions for the mountain front to the north, east of the area described by Mansfield. The relations of the late Cretaceous and early Tertiary rocks in this region, however, studied recently by Rubey, ${ }^{57}$ are more complicated than Schultz thought them to be.

Although the precise ages of the Laramide movements have not been determined, the conformable Upper Cretaceous strata in western Wyoming indicate that the main thrusting is of late Montana or younger age and therefore that it occurred at a date later than the early Laramide movement of central Utah. Available evidence admits the possibility of early Laramide deformation in southeastern Idaho that did not affect the rocks in western Wyoming east of the Wasatch lineament. In fact, the Coalville district of northern Utah ${ }^{58}$ shows a section, arched into an anticline, in which there are no angular breaks as high as the conglomerate of Echo Canyon, originally identified as basal Wasatch but, as studied in the field by the writer, probably older, although clearly not older than late Montana. The conglomerate itself bespeaks orogeny not far to the west, possibly contemporaneous with the early Laramide movement of central Utah.

Farther north, between northern Wyoming and southern Canada, a maximal thrusting, or at least that which penetrated farthest plainsward, occurred after the Fort Union. 59 Angular unconformity proving an upper age limit is generally lacking. The Heart Mountain thrust, definitely placed by Hewett ${ }^{60}$ between the middle Eocene and the Oligocene, appears to be an unusual type of structure ${ }^{61}$ and possibly not connected with the main Laramide orogeny. In the western part of the Bighorn Basin there is an angular unconformity between the Lance and the Fort Union, described by Hewett ${ }^{62}$ and interpreted by him to represent mild, local warping; this appears to be the only instance on record of angular break between these two units. In this region the main disturbance appears to have occurred be-

\footnotetext{
${ }^{51}$ Mansfield, G. R., op. cit., pp. 169-170, 198-199.

B2 Mansfield, G. R., op. cit., p. 109.

53 Veatch A. C. Geography and geology of a portion of southwestern Wyoming: U. S. Geol. Survey Prof. Paper 56, pp. 88-96, 1907.

${ }_{54}$ Veatch, A. C., op. cit., pp. 75,76 .

${ }_{55}$ Reeside, J. B., Jr., in Gregory, H. E., and Moore, R. C., The Kaiparowits region: U. S. Geol. Survey Prof. Paper 164, p. 113, 1931.

${ }^{56}$ Schultz, A. R.. Geology and geography of a portion of Lincoln County, Wyo.: U. S. Geol. Survey Bull. 543, p. 77, pls. 1, 3, 1914.

${ }^{58}$ Wegemann, C. H., The Coalville coal field, Utah : U. S. Geol. Survey Bull. 581, pp. 162-171, 1915 .

${ }^{59}$ Bevan, Arthur, Geology of the Beartooth Mountains : Jour. Geology, vol. $31, p, 454,1923.0$ R. so Hewett, D. F., The Heart Mountain overthrust : Jour. Geology, vol.

28. pp. 536-558, 1920. Bighorn region: Geol. Soc. America Bull., vol. 45, pp. 176-177, 1934. Bucher, W. H. Remarkable local folding, possibly due to gravity, bearing on the Heart Mountain thrust problem [abstract]: Geol. Soc. America Proc. 1935, p. 69, 1936 .

${ }_{62}$ Hewett, D. F., Geology and oil and coal resources of the Oregon Basin, Meeteetse, and Grass Creek Basin quadrangles, Wyo. : U. S. Geol
} Survey Prof. Paper 145, pp. 35-36, 1926. 
tween the Fort Union and the Wasatch, possibly the same as the Lewis thrust movement at the north. It is interesting to observe, however, that recent studies in Saskatchewan ${ }^{63}$ reveal a notable pre-Lance disconformity, as well as a stronger one between the Fort Union and the Wasatch.

None of this northern territory affords proof of strong early Laramide movement. Recently, however, Wilson ${ }^{64}$ has interpreted the Judith River sediments northeast of the Beartooth Mountain in southwestern Montana to indicate the beginning of Laramide orogeny there. The evidence adduced by Wilson clearly signifies changes in the source land to the west, and even if it does not prove actual folding, it is at least highly suggestive in light of the determination for central Utah. It is important to keep in mind that the data available for the Rocky Mountains of Montana and Wyoming in general do not prove absence of orogeny in Montana time; they show only that any movement so early did not penetrate as far eastward as did the post-Fort Union movement, and, to judge by such features as the Lewis overthrust, was not so powerful. The possibility of early Laramide folding in this region seems perfectly clear, and, in terms of Wilson's interpretation, rather likely.

East of central Utah lies the relatively inert Colorado Plateau, which was not strongly penetrated by the intense folding of surrounding parts of Utah and Colorado. It was deformed, however, into the gigantic monoclines and swells early made classic by Powell, Dutton, and Gilbert, in a movement generally ascribed to the Laramide disturbance, ${ }^{65}$ dated with respect to beds assigned to the Wasatch formation that may be the same as the Price River and North Horn formations of central Utah. These structures may therefore belong in the early epoch of folding, but to the writer the possibility seems stronger that they were formed at the time of the pre-Flagstaff movement, as is pointed out farther on.

North of the Colorado Plateau lie the cross-trending Uinta Mountains, whose structural relation to the northtrending ranges farther west is still an open question, ${ }^{6}{ }^{6}$ as is also the date of the earliest folding. Those students of the range who have committed themselves place the folding at the end of the Cretaceous. The most recent contribution, by Forrester, ${ }^{67}$ presents an analysis of the structure in which two epochs of disturbance are recognized, the first of which is dated at the close of the Cretaceous and held to be simultaneous with the main folding in the Wasatch range. The stratigraphic basis for the age assignment, however, is not well established, and the structural arguments are not conclusive. ${ }^{68}$ The initial Uinta folding may possibly have occurred at the end of the Cretaceous, but it could hardly have been simultaneous with that of the Wasatch Mountains; this is evident from data already presented in this paper, and there are many facts in the central Wasatch-Uinta mountain region that point toward the same conclusion. For one thing, purely structural evidence in the Wasatch Mountains indicates difference in time of folding. Calkins ${ }^{69}$ and others have shown that structural features of the Wasatch lineament are penetrated by intrusive masses allied with the Uinta arch; it seems clear that at least the intrusional phase of the Uinta disturbance was later than the Wasatch folding, but this phase may have occurred in the second epoch recognized by Forrester. That the initial Uinta folding was later than that of the Wasatch Mountains is further suggested by known conditions farther east in the Uinta range, where rocks much younger than the Price River formation of central Utah are involved in the folding. On the north flank of the main range precise stratigraphic evidence is lacking. On the south flank the youngest strata involved in the folding have been identified as the Mesaverde formation, of Montana age, whereas the Tertiary beds of the Uinta Basin overlap the Cretaceous and older formations; the basal part of the Tertiary section has been identified as the Wasatch formation. ${ }^{70}$ Reconnaissance examination has convinced the writer that the identification of the Wasatch formation is wrong in some places, as in the Vernal district, and is open to doubt elsewhere. The identification of the youngest strata in the folded series as Mesaverde is likewise open to question; as seen by the writer on $\mathrm{Du}$ chesne River below Hanna, these strata resemble strongly the later Cretaceous of areas to the southwest, and this adds to the suggestion of folding later than Montana. Furthermore, although the strata of the Uinta Basin overlap the Cretaceous formations, the contact is by no means sharply angular in the eastern part of the range, and beds as high as the Uinta formation, of late Eocene age, are tilted as strongly, or almost so, as the Cretaceous. ${ }^{71}$ This condition is also evident in the eastern prolongation of the Uinta axis, in northwestern Colorado, where in general there is no angular break in the column as high as the Green River formation. ${ }^{72}$ On Vermillion Creek, however, Sears ${ }^{73}$ has mapped the Wasatch formation in angular unconformity over tilted Mesozoic and Paleozoic rocks, and for the eastern end of the Uintas, on the north flank, Schultz has shown similar relations on his map and sections, without discussing them. ${ }^{74}$ It is not certain that this formation is Wasatch in age, although the likelihood appears stronger than at other places discussed in this paper, because in the territory east of Vermillion Creek, north of the Uinta axis, there is a rather complete section in which the Lance and Fort Union are probably represented by the Laramie and post-Laramie of former usage. ${ }^{75}$ These beds are overlain by strata assigned to the Wasatch. In this section, although there is no angular unconformity, a strong disconformity overlain by the basal conglomerate of the so-called post-Laramie formation suggests the initiation of folding in territory nearer to the mountains between Lance and Fort Union times.

\footnotetext{
${ }^{63}$ Fraser, McLearn, and others, Geology of southern Saskatchewan : Geol. Survey Canada Mem. 176, 1935.

${ }^{64}$ Wilson, C. W., Jr., Geology of Nye-Bowler lineament, Stillwater and Carbon Counties, Mont. : Am. Assoc. Petroleum Geologists Bull., vol. 20, p. $1185,1936$.

${ }^{65}$ Baker, A. A., Geologic structure of southeastern Utah : Am. Assoc. etroleum Geologists Bull., vol. 19, pp.

${ }^{66}$ Gilluly, James, op. cit., pp. 71-73.

${ }^{67}$ Forrester, J. D., Structure of the Uinta Mountains : Geol. Soc. America Bull., vol. 48 , pp. $631-666,1937$.

68 Spieker, E. M., Comment on paper by J. D. Forrester: Geol. Stoc. America Bull., vol. 48, pp. 2037-2043, 1938

${ }^{69}$ Calkins, F. C., in Butler, B. S., and others, The ore deposits of Utah: U. S. Geol. Survey Prof. Paper 111, pp. 251-254, 1920.

${ }^{70}$ Lupton, C. T., The Deep Creek district of the Vernal coal field, Wasatch County, Utah: U. S. Geol. Survey Bull. 471, pp. 585, 607-608,

1912. Forrester, J. D., op. cit.

${ }^{71}$ Spieker, E. M., Bituminous sands
Geol. Survey Bull. 822, pp. $80-82,1930$. ${ }^{2}$ Gale, H. S., Coal fields of northwestern Colorado and northeastern Utah. U. S. Geol. Survey Bull. 415, pp. 40-44, 72-86 (especially p. 84) 1910.

${ }^{73}$ Sears, J. D., Geology and oil and gas prospects of part of Moffat County, Colo., and southern Sweetwater County, Wyo. : U. S. Geol. Survey Bull. 751, pp. 291-293, pl. 35, 1924.

${ }^{74}$ Schultz, A. R., Oil possibilities in and around Baxter Basin, in the Rock Springs uplift, Sw

${ }_{75}$ Reeside, J. B., Jr., personal communication.
} 
In general, then, the evidence seems to show that the orogenic history of the Uinta Mountains began notably later than that of the Wasatch Mountains. The central part of the Uinta arch may have begun to rise near the close of the Cretaceous, but the eastern extension of the axis was not strongly disturbed before the deposition of the Green River formation, probably in middle Eocene time.

Farther east and south, in the Colorado Rockies, the Upper Cretaceous rocks appear to show no sign of disturbance comparable to the early Laramide of central Utah. There is no need to review here the extensive literature on that area; interpretations might perhaps be made of some sections to suggest Upper Cretaceous disturbance, but in the present state of knowledge they would be necessarily inconclusive. The disturbance recorded by the conglomerate at the base of the Arapahoe formation, discussed in a foregoing section of this paper, was probably local and not profound. The principal orogeny in the Rocky Mountains of Colorado probably came after the close of the Cretaceous, at a date not yet established.

\section{PRE-FLAGSTAFF MOVEMENT}

The disturbance here called the pre-Flagstaff movement is postulated on the basis of the unconformity beneath the Flagstaff limestone, whose essential features, and especially those that bear on the question of orogeny, are described and discussed in the parts of this report devoted to the North Horn and Flagstaff formations. As here interpreted, this movement produced a single fold, probably asymmetrical, steeper on the east, and not more than 5 or 6 miles wide. It was confined to the belt now occupied by Sevier and Sanpete Valleys and parts of the western margin of the Wasatch Plateau. The disturbance probably did not affect the rocks in the Gunnison Plateau, where the North Horn and Price River formations are present and conformable with the Flagstaff. It is possible, as pointed out in the discussion of the Flagstaff limestone, that the structure is limited to a small area around the MantiSalina district. Although its actual extent is not vet absolutely demonstrated, this fold is thought to occupy at least the southern half of the western border of the Wasatch Plateau, and perhaps more.

The folding took place within the rather narrow stratigraphic interval between the uppermost North Horn and the basal Flagstaff. Despite this precise evidence of position in the local stratigraphic column, however, the age of the movement is not accurately known, because of uncertainty as to the age of the Flagstaff limestone. Available data, presented elsewhere in this report (p. 136), suggest an age near the middle of the Paleocene. If this assignment is correct, there are no known episodes of folding in the eastern part of the Cordillera with which the central Utah disturbance might be correlated, possibly excepting the movement that occurred in southwestern Wyoming during the interval between Adaville and Evanston time..$^{76}$ If the Flagstaff limestone should prove to be of Wasatch age, the folding might be shown to be contemporaneous with that which occurred between Fort Union and Wasatch time in areas farther north; but the evidence now available on the age of the Flagstaff suggests Fort Union rather than Wasatch. A middle Fort Union movement would add to the complexity of the Cordilleran orogenic succession, and a simpler interpretation might seem more desirable, but it is the writer's judgment, in estimate of the regional stratigraphy, that the movement took place before the close of Fort Union time.

It is interesting to compare the known outlines of the central Utah fold with monoclines of the Colorado Plateau in southern and eastern Utah. ${ }^{77}$ Although the west flank of the fold is buried beneath alluvium in Sanpete and Sevier Valleys, exposures of the North Horn and Flagstaff formations on the west sides of the valleys and adjacent highlands suggest that it was originally gentler than the east flank, and that the fold was the sort of monocline typified by the East Kaibab and Waterpocket flexures of southern Utah. These structures have been interpreted by Baker ${ }^{78}$ as the result of deep-seated compressive forces, which produced steep overthrusts in the underlying basement and died out upward, and which are represented at the present surface by the strongly asymmetrical upwarps. This opinion had been reached by the writer independently in an attempt to visualize the regional tectonics.

The Sanpete Valley structure differs from those of southern Utah in being somewhat more complex, but certain features of the complexity support the concept of deep-seated thrusting. The pre-Flagstaff flexure is superposed on an older fold, the easternmost anticline of the early Laramide orogeny, but instead of renewing movement on all of the older anticline, as it probably would have done if caused by general compression in the upper layers, it is restricted to the eastern part of the early fold. This suggests partly independent structural control; the older anticline may have played a part in localizing the later yield, and its longer gentle flank may have served as a strut in which the stress was concentrated, but the localization of the pre-Flagstaff flexure on the east flank of the early fold indicates concentration of forces different from those of the early Laramide compression; such resolution might well have resulted from a thrust rising steeply from below. The isolation of the pre-Flagstaff fold, like that of the southern Utah monoclines, argues against pressure pervading the upper layers and favors deep-seated movement concentrated in localized thrusts. These features of form and interpretation are impressive in suggestion of a common type of origin for the Sanpete Valley structure and those to the east and south.

The regional stratigraphic relations also give reason for suspecting a common origin. The monoclines in southern Utah involve the Kaiparowits formation, of late Cretaceous age, and are overlain nonconformably by strata assigned to the Wasatch formation. ${ }^{79}$ The Kaiparowits formation is no older than the Price River and may be younger; it contains dinosaurs suggestive of Lance age. The strata assigned to the Wasatch formation have yielded very few fossils and their age is uncertain. As is brought out in the foregoing description of the Flagstaff limestone, it is entirely possible that part of the Wasatch formation as described for southern Utah is equivalent to the Flagstaff of central Utah. All of it might just as well be, as far as regional evidence goes. The question probably cannot be settled short of finding diagnostic fossils, because the outcrops of central and southern Utah are separated, their nearest approach being about 25 miles. As matters stand,

\footnotetext{
76 Veatch, A. C., op. cit. p. 75.

${ }^{7}$ Gregory, H. E., and Moore, R. C., The Kaiparowits region : U. S. Geol. Survey Prof. Paper 164, pp. 116-124, pl. 17, 1931. Baker, A. A.. op. cit., fig. 2.

${ }_{78}$ Gaker, A. A., op. cit., pp. 1501-1502.
} 
with definite conclusion impossible, the writer is inclined to think, on the basis of considerable regional observation, that the Wasatch formation of the south is equivalent to the Flagstaff of central Utah and that the monoclines of the Colorado Plateau are contemporaneous with the pre-Flagstaff fold of Sanpete Valley.

\section{PALEOGEOGRAPHY AND GEOLOGIC HISTORY}

\section{DIAGRAMIIIATIC RECONSTRUCTIONS}

The facts now available for central, eastern, and northeastern Utah permit interpretation of geologic history and reconstruction of paleogeographic conditions sufficiently complete to justify representation. To this end the writer has prepared four block diagrams (fig. 21) which portray the geography of the northern half of Utah east of longitude $113^{\circ} \mathrm{W}$. at four critical stages in the Upper Cretaceous; they also show the development of the geosyncline and the regional structure up to the close of the Cretaceous. In order to show anything at all of the section in eastern Utah, the vertical scale of the diagrams is exaggerated a little less than four times. The mountain belts are highly generalized as to form and are intended merely to indicate rugged highlands in approximate position. It was found impracticable on the available scale to represent the precise type of topography that would have resulted from early dissection of known folded structures in the eastern Great Basin. As to general trend, the mountain areas are probably correctly placed. Latitude in interpretation of some of the data would permit alternative locations of some features; for example, in the diagram for the lower Colorado the site of Salt-Lake City is shown in the piedmont gravel belt, whereas that site may have been occupied by mountains. In the diagram for late Montana time the shore line is drawn to emphasize the maximum possible withdrawal of the sea, the intention being to bring out the extent of the Castlegate sandstone member of the Price River formation. The shore may actually have lain farther west at the time of maximum withdrawal.

The four diagrams necessarily show only generalized and representative conditions for their specific times, and they need to be supplemented by an account of the succession of events, or perhaps it is more appropriate to say that they serve as illustrations for the account of geologic history. The elements of this account vary considerably in certainty of interpretation, and the attempt is made by suitable qualification to indicate something of the relative certainty. It is impossible, however, to make this differentiation complete, and the reader may judge for himself, in terms of the facts given in foregoing parts of the report, the degree of eogency attaching to the postulated events.

\section{UPPER JURASSIC AND LOWER CRETACEOUS}

During the early and middle parts of Upper Jurassic time central Utah was invaded by the widespread sea that covered large parts of the Cordilleran and adjacent regions. ${ }^{80}$ In its earliest stages this sea spread gray mud and silt, locally with some limestone, over central Utah; but as time went on closed basins developed in which concentrated brines gave rise to beds of gypsum, locally thick and pure, but generally irregular, thin, and mixed with mud. Later, great quantities of red mud were deposited, and closed basins again developed, this time to form deposits of rock salt from the brines that were concentrated in them. Salt-forming conditions may have existed also in the early stages of the marine invasion. This succession of events, covering the deposition of the Twelvemile Canyon member of the Arapien shale, holds for the part of central Utah now occupied by the northern part of Sevier Valley, but reconnaissance observation suggests that, in other areas nearby, conditions were somewhat different. The zones so far recognized in the Arapien shale have not been well enough correlated across central Utah to make sure of the relative successions of events at different places; it is possible, for example, that the times of thick salt deposition in Sevier Valley correspond to times of thick gypsum deposition farther north and west, and it is known that to the north the early stages of the invasion were marked by lime-forming conditions.

At all places seen by the writer the salt occurs without gypsum, and the gypsum without salt. In the district near. Salina the two occur in different zones of the Arapien shale, as indicated in the order of deposition given above, but the relation of these deposits to other occurrences of salt and gypsum in nearby districts ${ }^{81}$ is not known. The apparent localization of the thick deposits of gypsum, and to some extent the salt also, suggests deposition in restricted basins of small area. The general problem of explaining such pure and mutually exclusive deposits as precipitate from sea water, though widely studied by geologists and chemists, has not been completely solved, and accurate reconstruction of conditions in central Utah during the Upper Jurassic is yet impossible; the geologic relations of the Utah deposits are not known in sufficient detail to afford a contribution to the problem. The features of distribution mentioned above, however, leave open the possibility that some such condition as that proposed by Branson ${ }^{82}$ may have existed; that is, many local basins separated by barriers high enough to prevent circulation of the deeper layers of water but low enough to allow free passage of partially saturated brines, with gypsum precipitating out in the basins nearest the open sea, and salt in the more remote basins to which only brine free of calcium sulfate had access. In fact, if it is ever possible to correlate the zones of the Arapien shale across the area, their occurrence may afford an interesting test of Branson's hypothesis; thick, pure salt beds occur in the northern part of Sevier Valley, and thick, pure gypsum near Nephi and Levan. However, even if the type of situation pictured by Branson does appear favorable, it must be remembered that nearly perfect balance is required to produce mutually exclusive and nearly pure deposits of salt and gypsum.

After the epoch of salt and gypsum deposition open sea again prevailed, and alternating layers of red and greenish-gray silt and mud were deposited, the red predominating, and occasional inroads of sand occurred. This condition lasted long enough for the deposition of 3,000 feet or more of sediment, the Twist Gulch member of the Arapien shale, and by the time the uppermost of these beds was laid down the geosyncline had been accentuated by the addition of 10,000 feet, more or less, of Jurassic sediments. The general similarity of these sediments to those of the same age in eastern Utah and

\footnotetext{
${ }^{80}$ Crickmay, C. H., Jurassic history of North America-its bearing on the development of continental structure: Am. Philos. Soc. Proc. vol. $70, \mathrm{pp} .87-89(\operatorname{maps} 8,9,10), 1931$.

${ }_{81}$ Eardley, A. J., Stratigraphy of the southern Wasatch Mountains, Utah: Mich. Acad. Sci. Papers, vol, 18, pp. 332-334, 1933.

82 Branson, E. B., The origin of thick gypsum and salt deposits : Geol.
} 


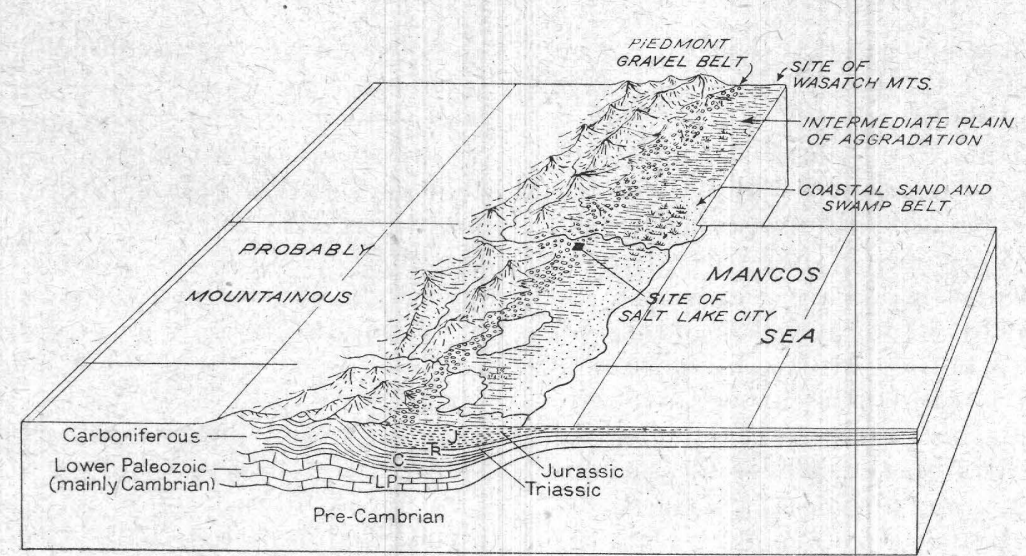

A. Early Colorado time

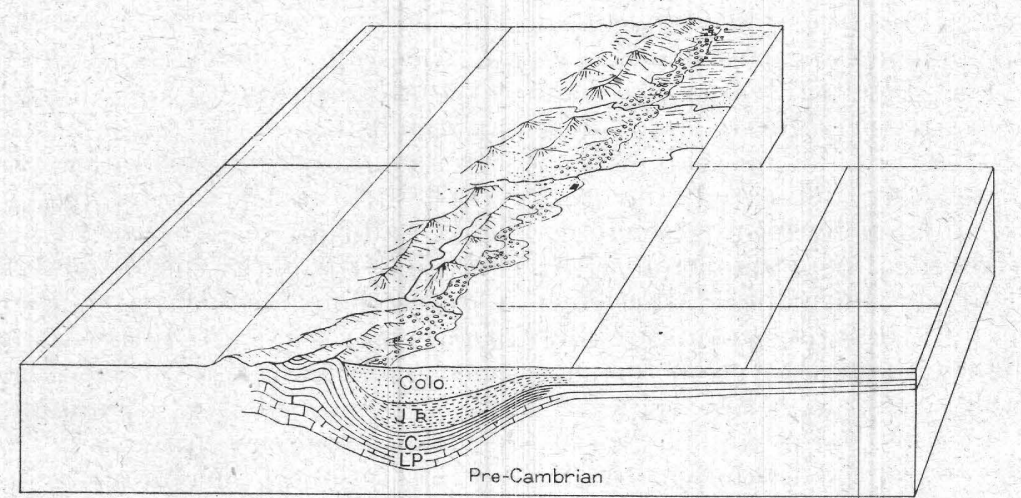

B. Late Colorado time

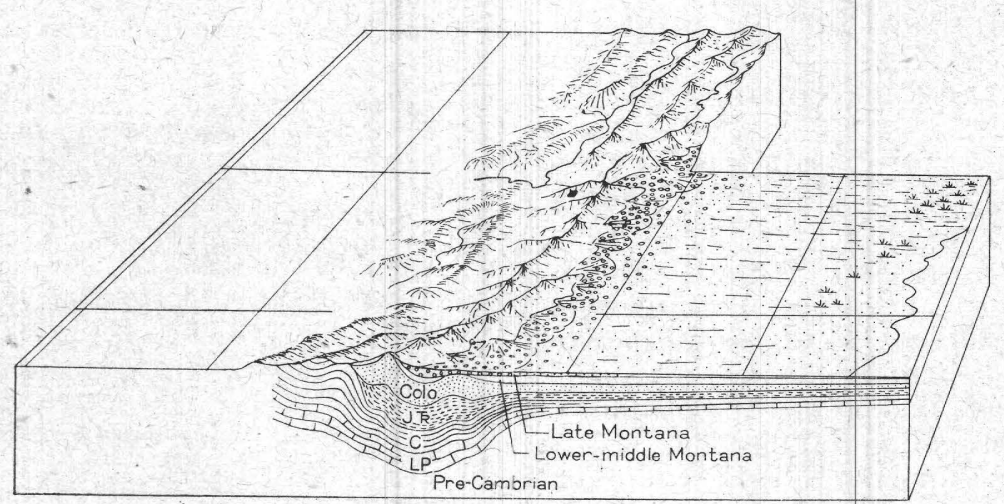

C. Late Montana time (Castlegate)

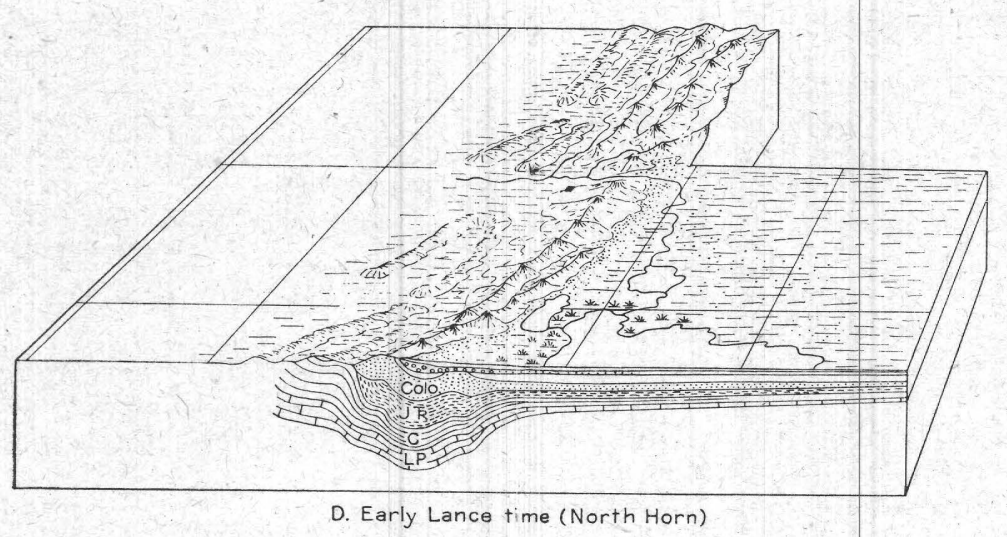

FIGURE 21.-Block diagrams showing Utah north of latitude $39^{\circ} 30^{\prime}$ at four stages in late Cretaceous time. 
the great difference in thickness $(10,000$ feet vs. 2,500$)$ testify to the pronounced but slow differential subsidence of the geosynclinal belt.

In the latest Jurassic time flood-plain sediments of the Morrison formation were deposited widely over the region to the east, but, as already discussed in this report (p. 126), it is not known whether they spread as far west as central Utah. For the closing stages of the Jurassic, then, the account of geologic history must yet be vague. Regardless of whether Morrison sediments were deposited in central Utah, the area began in late Jurassic time to undergo that remarkable period of stagnation which lasted through the Lower Cretaceous and produced the phenomenon, universal in the Colorado Plateaus, of basal Upper Cretaceous (Dakota? or lower Mancos) overlying undisturbed Morrison beds with no sign of angular discordance. During Lower Cretaceous time the area was almost certainly positive, and erosion was either phenomenally uniform or very sluggish, almost inactive. The writer prefers the second interpretation, although critical facts for basis of decision seem to be lacking; it is not inconceivable that Lower Cretaceous sediments were deposited and removed in a cycle of erosion incited by eustatic change of sea level an $\lambda$ carried to complete peneplanation with a base level near the top of the horizontal Morrison strata. Uplift uniform enough to allow erosion of the existing buried plain on the top of the Morrison formation is almost inconceivable. In any case, regional distribution of Lower Cretaceous sediments in North America does not favor the concept; the known basins of deposition do not suggest extension into the Colorado Plateaus. It is most likely that Lower Cretaceous time was geologically neutral in Utah.

\section{EARLY UPPER CRETACEOUS (COLORADO)}

Not long after the beginning of the Upper Cretaceous, an orogenic pulse penetrated the region, folding the rocks in a belt trending about N. $15^{\circ}$ E., which lay not far west of the present southern Wasatch Mountains. The highlands thrown up in this folding were rapidly eroded, and the debris resulting from this active destruction was swept eastward, boulders and coarse gravel accumulating to great thickness in the piedmont belt and finer sediments traveling farther out across the lowland area bordering the sea. In early Colorado time the lowlands east of the foothills were occupied in close order by flood plains and a coastal sand belt, the average total width of which from the margins of the gravel fans to the muddy bottom of the sea was less than 20 miles. At times there appeared locally on the flood plain small lakes in which limestone was deposited. These lakes were possibly caused by drainage obstruction incident to the rapid accumulation of coarse sediments, and those near the mountains may well have been impounded by coalescing gravel fans, after the fashion postulated by Eardley ${ }^{83}$ for similar lime-depositing lakes of later age. The lakes were surrounded by accumulations of highly varied sediments, in which brightly colored muds and sands abounded as well as gravel of many kinds. In parts of northern Utah, at approximately the same time, coal-forming swamps flourished on the coastal plain, not far from the sandy beach of the lower Mancos sea.

Through early Colorado time the distribution of environments above described was fairly uniform, but in late Benton (Carlile) time an arm of the sea invaded the belt east of the piedmont, cut off from the open sea to the east by a sandy peninsula that was repeatedly covered by coal-forming swamps. In Niobrara time the sea overswept this peninsula, for a while invading the piedmont gravel belt and skirting the foothills of the mountains. Toward the close of Niobrara time, perhaps in early Montana, a fresh volume of coarse gravel was spread eastward, probably due to renewal of uplift in the mountain belt and perhaps a genuine orogenic movement.

\section{THE GEOSYNCLINE}

By late Colorado time the accumulation of sediment in the piedmont belt had reached notable proportions, and a profound geosyncline occupied the site of the Wasatch Mountains; the Paleozoic and Mesozoic rocks totaled over 40,000 feet in thickness, most of which was in the huge masses of Pennsylvanian, Jurassic, and Cretaceous strata. This prodigious accumulation marks an extension of the regional trend in tectonic history, already noted for the Paleozoic ${ }^{84}$ of pronounced eastward shift in the site of heavy sedimentation. - From the Cambrian geosyncline of western Utah and eastern Nevada through the Carboniferous trough of the Oquirrh-southern Wasatch region to the eastern marginal depression of Jurassic and Cretaceous times the succession is most impressive, and although not in perfect scheme, yet is well enough developed to suggest a certain regularity in tectonic process. Several features of this regional development are worthy of notice, and, to serve as basis for brief discussion, the relevant events and conditions for the territory between western and central Utah are summarized in the following table.

Generalized record of sedimentation, Cambrian to Eocene, between western and central Utah

\begin{tabular}{|c|c|c|}
\hline $\begin{array}{c}\text { Approx- } \\
\text { imate age } \\
\text { (millions } \\
\text { of years), } \\
\text { as } \\
\text { generally } \\
\text { accepted }\end{array}$ & Divisions & Conditions and events \\
\hline & Cambrian & $\begin{array}{l}\text { Profound subsidence in western belt; } \\
\text { limestone deposition. }\end{array}$ \\
\hline $300-200$ & $\begin{array}{l}\text { Ordovician through Devonian.- } \\
\text { Carboniferous. }\end{array}$ & $\begin{array}{l}\text { Relatively positive conditions. } \\
\text { Profound subsidence in central-eastern } \\
\text { belt; sandstone and limestone deposi- } \\
\text { tion. } \\
\text { Relatively positive conditions. }\end{array}$ \\
\hline $150 \pm$ & Upper Jurassic & $\begin{array}{l}\text { Profound subsidence in eastern belt; } \\
\text { shale deposition, local limestone, } \\
\text { salt, gypsum. } \\
\text { Region totally positive. }\end{array}$ \\
\hline $100 \pm$ & Colorado_............... & Profound subsidence in eastern belt; \\
\hline $70 \pm$ & $\begin{array}{l}\text { Early Montana } \\
\text { Late middle Montana... } \\
\text { Late Montana........... }\end{array}$ & $\begin{array}{l}\text { Relatively positive conditions. } \\
\text { Early Laramide orogeny, eastern belt. } \\
\text { Profound subsidence in eastern belt; }\end{array}$ \\
\hline $55 \pm$ & $\begin{array}{l}\text { Lance and carly Fort Union... } \\
\text { Fort Union and Wasatch....... }\end{array}$ & $\begin{array}{l}\text { coarse clastic deposition. } \\
\text { Relatively positive conditions. } \\
\text { Pre-Flagstaft folding, } \\
\text { Minor geosyncline in western Uinta } \\
\text { Basin; lacustrine sedimentation. }\end{array}$ \\
\hline
\end{tabular}

It is evident that there were four epochs of major subsidence followed by two lesser ones, all separated by longer periods of relatively positive condition. These

83 Eardley, A. J., A limestone chiefly of algal origin in the Wasatch conglomerate, southern Wasatch Mountains, Utah: Mich. Acad. Sci. Papers, vol. 16, pp. 405-406, 1932 . It should be noted that the specific
theory here referred to does not hold for the limestone described by Eardley, which, as suggested by him in alternative hypothesis, is part of the extensive Flagstaff limestone.

84 Gilluly, James, Geology and ore deposits of the Stockton and Fairfield quadrangles, Utah : U. S. Geol. Survey Prof. Paper 173, p. 39, 1932 . 
time intervals, especially the longer positive periods, are progessively shorter in ascending order; each interim between epochs of strong and localized subsidence is roughly half as long as its predecessor. The epochs of geosynclinal accentuation seem to follow the same sort of rule as that brought out by Stille ${ }^{85}$ for orogenic pulses, in that compared to the intervals separating them they are episodic in nature, although doubtless more broadly so than the orogenies. Further, they recurred, shifting eastward, at regularly increasing pace. Whether this quickening of pulse is accidental cannot be said, but it does harmonize with the broad trend of the earth's tectonic history, in which the crowding of orogenic episodes toward the present is plainly evident, ${ }^{86}$ and it is thus another suggestion of crude regularity in crustal movement.

Another point worth noting is that the type of sedimentation changed progressively eastward, from dominantly lime-forming conditions in the older Paleozoic to coarse clastic deposition in the late Mesozoic. The coarse materials of the early upper Cretaceous geosyncline accumulated in a sort of foredeep fronting the newly folded belt, as did those also of late Montana time, and these phases of the geosynclinal development seem to be related somehow to the orogenic performance. The older geosynclinal phases probably were not associated with orogeny; sections known in the eastern Great Basin give no evidence of Paleozoic folding, but the territory has only been sampled geologically, and localized folding might remain to be discovered. Further, the record' of Triassic and Jurassic times in western Utah is notably incomplete.

Not only did the successive downwarps come closer to one another in time, but they crowded together in space as well. The areas of thick Pennsylvania and Jurassic overlap, and the thick Jurassic is practically coincident with the thick Cretaceous, whereas the areas of thick Cambrian are more than 150 miles west of the thick Pennsylvanian.

Another point of interest that might be noted in connection with the sediments of the geosyncline is the resemblance of the Indianola group and the Price River and North Horn succession to the Alpine Flysch and Molasse. Especially close is the similarity between the Price River and North Horn formations and the Molasse as described by Heim ${ }^{87}$; even down to details of lithologic character and distribution of sediments the two agree remarkably. The writer has never seen the Molasse and is aware of the danger in making close comparisons from written descriptions alone, but Heim's account is so clear that little doubt is possible. The only important difference is that the Price River and North Horn, although locally folded and thrust in the western part of the Wasatch Plateau and adjacent country on the west, are neither so extensively nor so profoundly deformed as the Molasse of Switzerland.

\section{EARLY TO MIDDLE MONTANA}

In early Montana time the sea, which had reached its greatest local extent in Niobrara time, began slowly to retreat, oscillating or pausing in its eastward movement so that the littoral and bordering continental sediments intertongue with the offshore marine beds. In the geosyncline sedimentation diminished in volume, the floor sinking more slowly, and finer sediments were deposited; the highlands to the west had been worn down to a stage at which the streams were near grade.
In the folded belt positive evidence of this condition is lacking, but it is inferred from the Montana sediments not far east of the marginal fold. In middle Montana (Blackhawk) time coal-forming swamps overspread the region more widely than ever, and the thick coal beds of the present Wasatch Plateau were laid down. Following the eastward migration of the sea, the belt of extensive coal swamps, always near shore, moved eastward into the region of the Book Cliffs, and in central Utah the latter part of middle Montana time brought extensive inland flood plains on which fine sands and muds were spread but which supported few coal swamps. By the time the uppermost strata of the Blackhawk formation were deposited the shore had retreated far to the east, to the region east of the present location of Green River.

\section{LATE MONTANA AND LANCE}

Following the deposition of the Blackhawk sediments came a sharp orogenic paroxysm, the early Laramide, in which the sediments of the geosyncline were folded and thrust eastward, the rising mass being rapidly cut by erosion into rugged mountains. The resulting rock debris was vigorously swept eastward, spreading into the marine basin to form the gigantic tongue of the Castlegate sandstone member of the Price River formation. In the newly formed piedmont district pediments developed much like those of the present-day, which are widespread in the Cordilleran region, and these pediments were deeply buried under coarse rubble. At least in the vicinity of the 40th Parallel the mountain front was steep and several thousand feet high; Eardley ${ }^{88}$ estimates over 10,000 feet, and it may have approached that figure, but the estimate takes no account of movements since the deposition of the conglomerate and is based on uncertain assumptions respecting the amount of post-orogenic erosion; it may be too high. The preFlagstaff and later movements, which were strong east of the southern Wasatch Mountains, doubtless altered the original relations between the conglomerate and the parent mass and may have raised the mountain block. At all events, the mountains were high, and it is interesting to observe that in general contour they were much like the southern Wasatch of today; the line of their east front virtually coincides with that of the east front of the Wasatch range south of Spanish Fork, and they ended in a southern promontory, the forerunner of Mount Nebo. The site of the Gunnison Plateau was overswept by Price River sediments, which now overlie the Indianola strata in mildly angular unconformity, near the axis of a broad syncline that separates the southern continuation of the Mount Nebo anticline from the easternmost fold in the Sanpete Valley district. In the central belt of this syncline the Indianola strata were only slightly eroded before the Price River gravels overspread the region. The anticline to the east, however, was completely truncated, as seen in the widespread surface beveling the Indianola deposits, on which the basal conglomerate of the Price River formation was deposited in the western Wasatch Plateau and the eastern Gunnison Plateau. The mountain front probably veered southwestward

\footnotetext{
${ }_{85}^{85}$ Stille, Hans, Grundfragen der vergleichenden Tektonik, p. 44, 1924.
86 Stille, Hans, The present tectonic state of the earth: Am. Assoc. ${ }^{86}$ Stille, Hans, The present tectonic state of
Petroleum Geologists Bull., vol. 20, p. 852, 1936 .

${ }_{87}$ Heim, Albert, Geologie der Schweiz, vol. 1, pp. 39-95, Leipzig, 1919 88 Heim, Albert, Geologie der Schweiz, vol. 1, pp. s9-95, Leipzig, 1919. Mountains, Utah : Mich. Acad. Sci. Papers, vol. 19, pp. 391-392, 1934.
} 
from the site of Mount Nebo, lying west of the present Gunnison Plateau; the overturned fold of Mount Nebo swings sharply westward in strike at the southern end of the Wasatch Mountains. (See fig. 21.)

As the early Laramide mountains were worn down, successive profiles of depositional equilibrium were attained in the aggradational belts to the east, and the flood-plain areas shifted westward; the finer sediments now constituting the North Horn formation were deposited closer and closer to the mountains until they overlapped the remains of the steep front and partly buried it in the latitude of Thistle. Gravel fans continued to exist, however, as the dominant sediment in the narrow piedmont belt. The flood plains were occupied by shifting lakes in which the limestone and evenly bedded silts of the North Horn formation accumulated. This type of sedimentation went on through the close of the Cretaceous and continued without interruption into Paleocene time.

\section{PALEOCENE (FORT UNION)}

Not long after the beginning of Tertiary time, as judged by the thickness of sediment deposited, the belt now occupied by Sanpete and Sevier Valleys was disturbed by the movement described in this report as the pre-Flagstaff movement. This disturbance produced a single anticline in the eastern part of the valley belt and the foothills of the Wasatch Plateau, to both east and west of which sedimentation apparently went on without interruption, the flood plains receiving fine sands and muds exactly as before the disturbance. The anticline was planed off by erosion, and after the development of a nearly level erosion surface on the folded Cretaceous and Jurassic rocks the entire region from central Utah eastward as far as the western Book Cliffs was overswept by a shallow lake in which the dominantly calcareous sediments of the Flagstaff limestone were deposited. This lake may have resulted from obstruction of drainage produced by the pre-Flagstaff deformation; reasons have been given for suspecting that this movement was widespread in central, eastern, and southern Utah. It may, on the other hand, have resulted from geosynclinal downwarping. As time went on the lake slowly changed in outline and in configura- tion of bottom, spreading different kinds of sediment in complicated intertonguing layers and lenses; deltas encroached on it, the marginal flood plain following, and for a time in the central part of the Wasatch Plateau an enclosed basin contained saline waters from which gypsum was deposited. In the main, however, the early stages of the Flagstaff lake were a time of widespread clear water, in which limestone was deposited, covering all of central Utah and probably much territory beyond. At this time began the long series of volcanic outbursts that were to dominate the scene in later Tertiary timelocally the Flagstaff limestone contains interbedded fine white ash, probably rhyolitic in composition.

\section{EOCENE (WASATCH AND GREEN RIVER)}

At this stage the dating of events becomes less precise, and it is impossible for lack of diagnostic fossils to interpret the beds above the Flagstaff in terms of the standard Eocene time scale. Approximately in Wasatch time, however, flood-plain sediments swept into the region from the east, blotting out much of the Flagstaff lake and spreading over most of central Utah. At the maximum extent of the flood plain the lake shore extended from the country west of Soldier Summit southwestward, curving back and forth across the territory now occupied by Sanpete and northern Sevier Valleys. Later the lake again expanded eastward, the shore line oscillating and producing intricately interfingered bodies of sediment, until it attained maximum extent at the time the major body of the Green River formation was deposited. The paleogeography of this remarkable lacustrine development has been well worked out by Bradley. ${ }^{89}$ In the western districts the lake persisted through the time of deposition of the Wasatch sediments farther east, but the type of sediment changed from dominantly limestone to dominantly mud, some of it sapropelic and destined to become oil shale. In the Uinta Basin the remainder of Eocene time is fully recorded in the Bridger and Uinta formations, but in central Utah the Green River strata are the youngest that are even approximately placed in the time scale.

${ }^{89} \mathrm{Bradley}, \mathrm{W} . \mathrm{H}$., The varves and climate of the Green River epoch : U. S. Geol. Survey Prof. Paper 158, pp. 87-110, 1930. 


\section{INDEX}

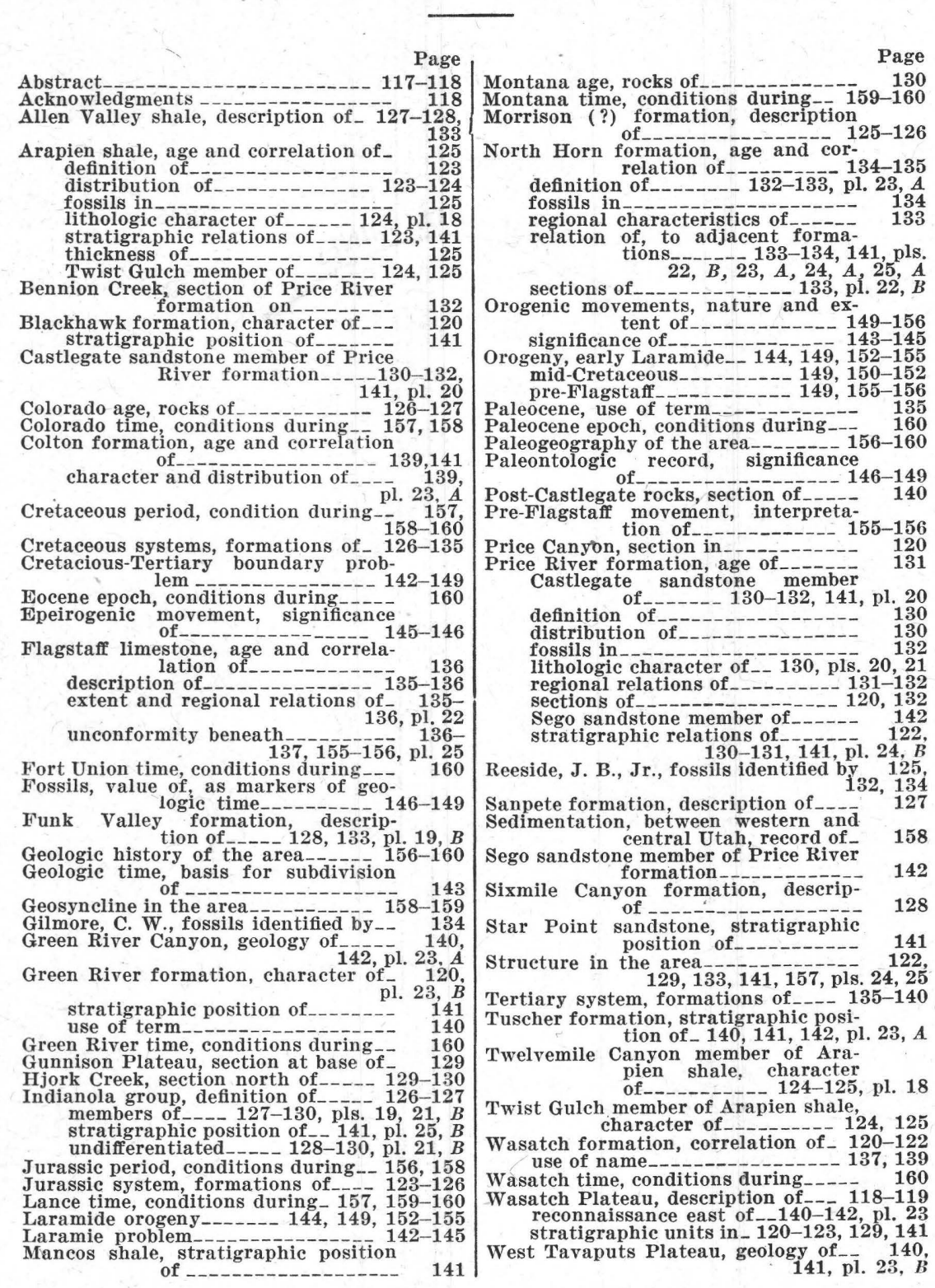

